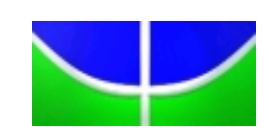

UNIVERSIDADE DE BRASÍLIA - UnB

PROGRAMA DE PÓS-GRADUAÇÃO EM GESTÃO PÚBLICA (PPGP)

MESTRADO PROFISSIONAL EM GESTÃO PÚBLICA

Gestão por processos organizacionais na Universidade de Brasília: estudo de caso

Kelli Adriane de Carvalho

\title{
Brasília-DF
}

2015 
Kelli Adriane de Carvalho

\section{Gestão por processos organizacionais na Universidade de Brasília: estudo de caso}

Dissertação apresentada no Programa de Pós-

Graduação em Gestão Pública, da Faculdade UnB Planaltina, para o grau de Mestre em Gestão Pública.

Orientador: Prof. Dr. Jonilto Costa Sousa

Brasília-DF

2015 
Ficha catalográfica elaborada automaticamente, com os dados fornecidos pelo(a) autor(a)

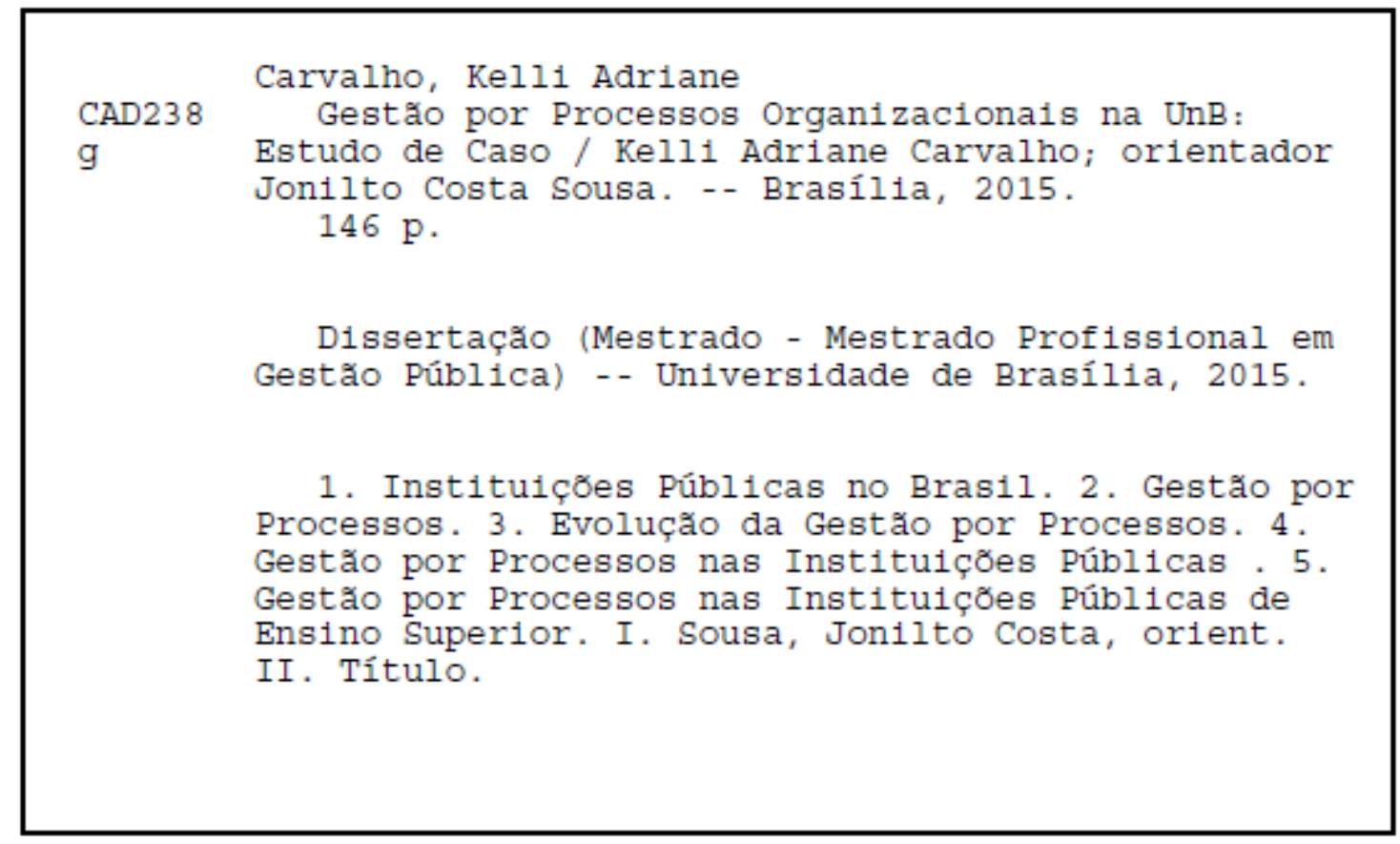


Kelli Adriane de Carvalho

\section{Gestão por processos organizacionais na Universidade de Brasília: estudo de caso}

Dissertação de Mestrado Aprovada pela seguinte comissão examinadora:

Prof. Dr. Jonilto Costa Sousa

Universidade de Brasília - UnB

Orientador

Prof $^{\mathrm{a}}$. Dr ${ }^{\mathrm{a}}$. Anitta Valléria Calmon Mendes

Universidade de Brasília - UnB

Examinadora - Membro Interno

Prof. Dr. José Matias-Pereira

Universidade de Brasília - UnB

Examinador - Membro Externo 
Dedico este trabalho à minha família, por sua capacidade de acreditar e investir em mim.

Obrigada pela paciência, pelo incentivo, pela força e principalmente pelo carinho. 


\section{AGRADECIMENTOS}

Ao Prof. Dr. Jonilto Costa Sousa que, com paciência e sabedoria, me orientou e me mostrou o caminho a seguir, sempre acessível, pelas observações pertinentes, pelo companheirismo e considerações excepcionais. Que este trabalho não tenha sido apenas um fim ou uma meta a ser alcançada, mas possibilite novas interações e estudos.

A todos os professores do Programa de Pós-Graduação em Gestão Pública que ajudaram na minha formação teórica, por meio dos seus ensinamentos.

À Equipe da Diretoria de Processos Organizacionais que me proporcionou um período de estudo, pesquisa e visitas à Diretoria, colaborando substancialmente para a realização e enriquecimento deste estudo.

Aos demais participantes da pesquisa, que se dispuseram a fornecer informações fundamentais em relação ao tema de pesquisa, relatando experiências e percepções.

Ao revisor Átila Rabelo, pelo empenho e excelente trabalho de revisão e confecção deste estudo, mesmo diante da minha correria e pressão.

Aos meus amigos da $1^{\text {a }}$ Turma do Programa de Pós-graduação em Gestão Pública da Faculdade UnB Planaltina, pelo apoio e companheirismo em tempos difíceis, e por proporcionarem valiosos momentos de alegria durante todo o mestrado.

Aos amigos Leandro Evangelista e Rogério Alves, companheiros de trabalho e irmãos na amizade que fizeram parte dessa caminhada e que vão continuar presentes em minha vida com certeza.

À minha amiga e irmã Tânia Cruz, pelo incentivo e apoio constante.

Ao meu noivo Luis Felipe, pelo carinho, compreensão, companheirismo e, principalmente, paciência ao longo dessa jornada.

À todos os meus familiares, avós, irmão, cunhados e sobrinhos, em especial aos meus pais, Rui e Marisa, meus alicerces, fonte de inspiração, por sempre me mostrarem o caminho certo a ser seguido, me apoiando e incentivando para a realização dos meus sonhos e metas.

E por fim, à Deus, a quem me apeguei e busquei forças diariamente para não desistir diante das dificuldades. Hoje eu só quero dizer: obrigada meu Deus! 
"Agradeço todas as dificuldades que enfrentei, não fosse por elas, eu não teria saído do lugar...

As facilidades nos impedem de caminhar.

Mesmo as críticas nos auxiliam muito."

(Chico Xavier) 


\section{RESUMO}

Este estudo investiga o processo de evolução da Universidade de Brasília em termos de uma instituição orientada por processos, como consequência da necessidade em se adotar uma gestão focada em resultado, no desempenho, nos clientes e na substituição de uma estrutura hierárquica e centralizada para uma menos centralizada. Com base na literatura pertinente ao tema, foram apresentadas e discutidas diversas concepções teóricas acerca da gestão por processos, focalizando na metodologia utilizada para sua implantação, bem como nos fatores críticos de sucesso decorrentes dessa implantação. Sob a forma de estudo de caso, os resultados obtidos por meio de análise documental e entrevistas semi-estruturadas possibilitaram a categorização desse modelo na Instituição pesquisada. Foram identificadas quatro categorias relacionadas a origem, propósitos estratégicos, vantagens e dificultadores para essa adoção, assim como a metodologia utilizada e os processos críticos diagnosticados. Conclui-se que a gestão por processos permite à Instituição ter capacidade de se adequar às mudanças sociais, políticas e tecnológicas, de modo a possibilitar uma flexibilidade e eficiência, proporcionando a melhoria contínua dos processos administrativos e organizacionais, e gerando serviços de qualidade e que atendam satisfatoriamente às necessidades do cidadão.

Palavras-chave: processos; gestão por processos; instituições públicas brasileiras. 


\begin{abstract}
This study investigates the process of evolution at the University of Brasilia in terms of an institution guided by processes as a result of the necessity to adopt a management focused on results, performance, customers and the replacement of a hierarchical and centralized structure to a less centralized. Based on the literature concerning the matter has been presented and discussed various theoretical conceptions of process management, focusing on the methodology for its implementation as well as the critical success factors resulting from this deployment. In the form of case study, the results obtained by means of document analysis and semi-structured interviews allowed the categorization of this model in the research institution. Four categories related to origin have been identified, strategic purposes, advantages and difficulties to this adoption, as well as the methodology used and diagnosed critical processes. We conclude that the process management enables the institution be able to adapt to social, political and technological, to enable flexibility and efficiency, providing continuous improvement of administrative and organizational processes, and generating quality services and satisfactorily meet the needs of citizens.
\end{abstract}

Keywords: processes; process management; brazilian public institutions. 


\section{LISTA DE QUADROS}

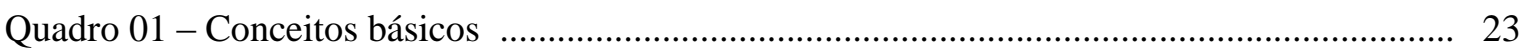

Quadro 02 - Atributos do Processo ............................................................................................ 24

Quadro 03 - Relação dos macro-objetivos e atividades do escritório de processos ...................... 45

Quadro 04 - Verbalizações sobre metodologia de implantação da gestão por processos............ 83

Quadro 05 - Processos críticos identificados na UnB .............................................................. 93 


\section{LISTA DE TABELAS}

Tabela 01 - Dados biográficos dos participantes 


\section{LISTA DE FIGURAS}

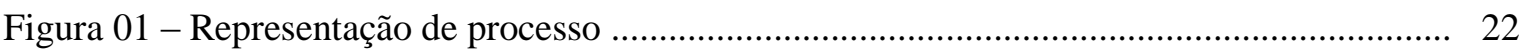

Figura 02 - Implantação do sincronismo organizacional através do redesenho dos processos $\quad \ldots \quad 38$

Figura 03 - Proposta de alocação do escritório de processos em uma gestão por processos ........ 46

Figura 04 - Alternativas de estruturas organizacionais.............................................................. 52

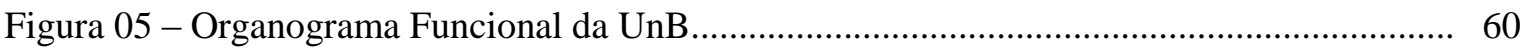

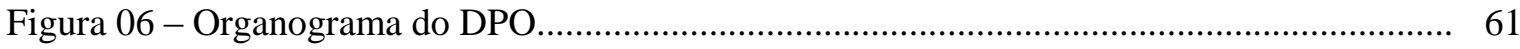

Figura 07 - Metodologia de transformação por processos......................................................... 84

Figura 08 - Fase 1 - Ambientação................................................................................... 85

Figura 09 - Fase 2 - Contextualização Estratégica................................................................ 85

Figura 10 - Contexto dos Macroprocessos Finalísticos e de Apoio............................................... 86

Figura 11 - Fase 3 - Mapeamento do Processo........................................................................... 87

Figura 12 - Fase 4 - Redesenho do Processo........................................................................ 89

Figura 13 - Implementação e Acompanhamento........................................................................ 90 


\section{SUMÁRIO}

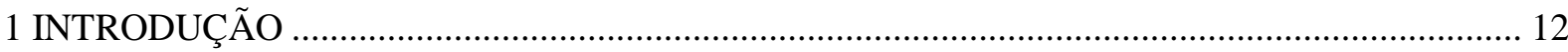

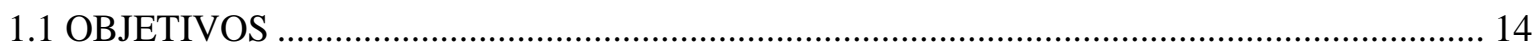

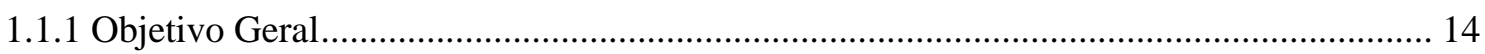

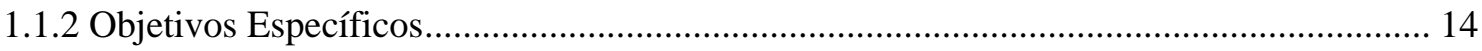

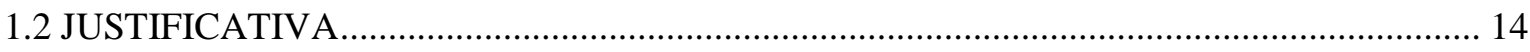

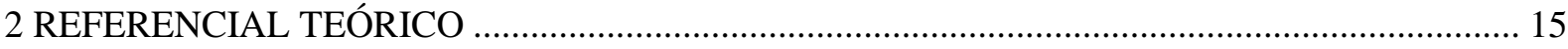

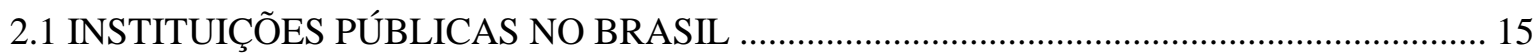

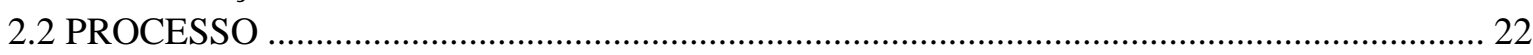

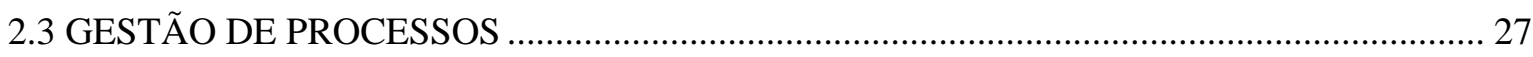

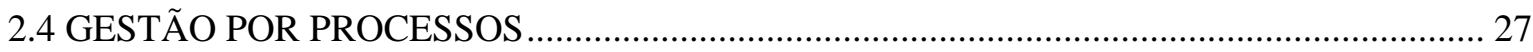

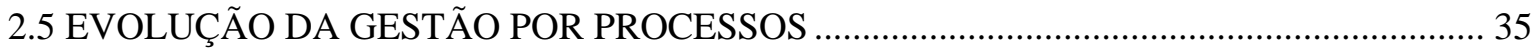

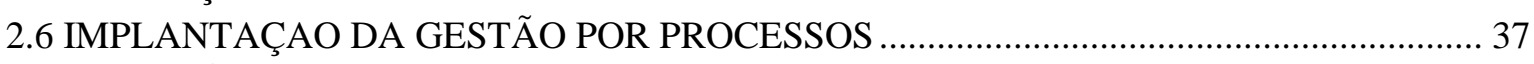

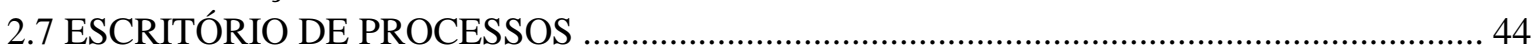

2.8 GESTÃO POR PROCESSOS NAS INSTITUIÇÕES PÚBLICAS ......................................... 48

2.9 GESTÃO POR PROCESSOS NAS INSTITUIÇÕES PÚBLICAS DE ENSINO SUPERIOR

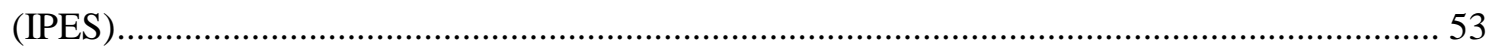

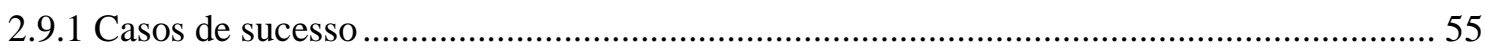

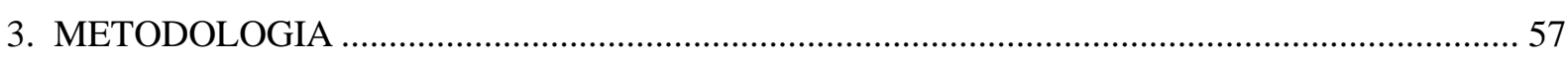

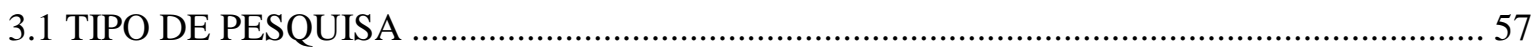

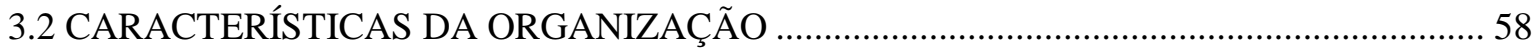

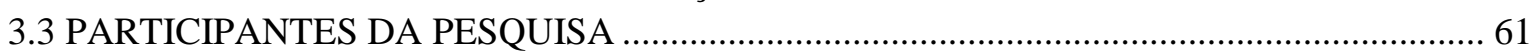

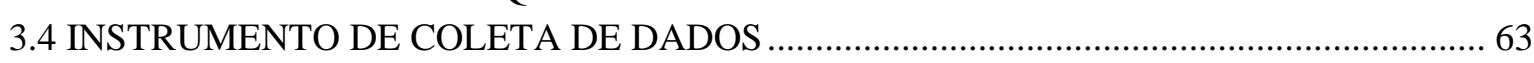

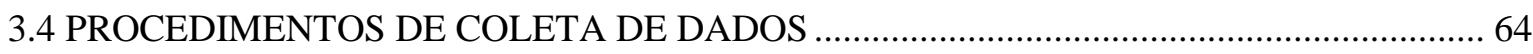

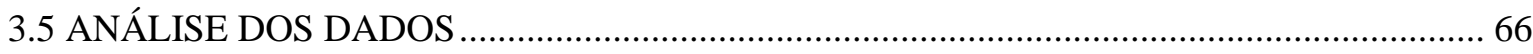

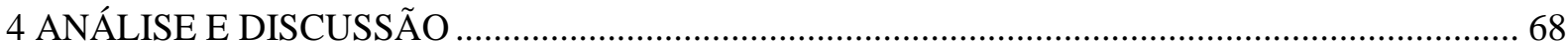

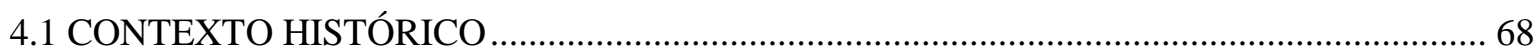

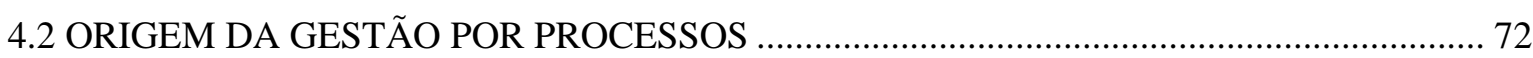

4.3 PROPÓSITOS ESTRATÉGICOS PARA ADOÇÃO DA GESTÃO POR PROCESSOS ......... 77

4.4 METODOLOGIA PARA IMPLANTAÇÃO DA GESTÃO POR PROCESSOS …...................... 83

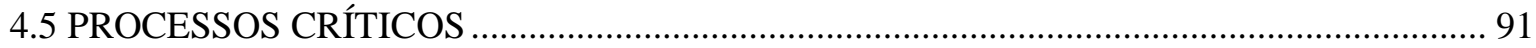

4.6 VANTAGENS NA ADOÇÃO DA GESTÃO POR PROCESSOS ............................................. 95

4.7 DIFICULTADORES PARA IMPLANTAÇÃO DA GESTÃO POR PROCESSOS ................. 98

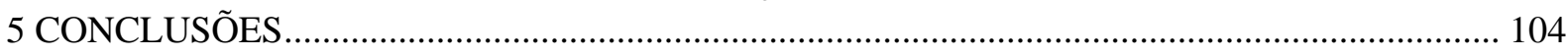

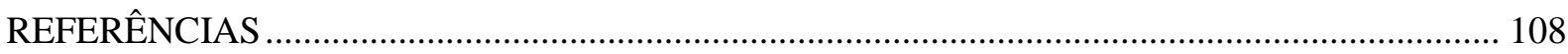

APÊNDICES

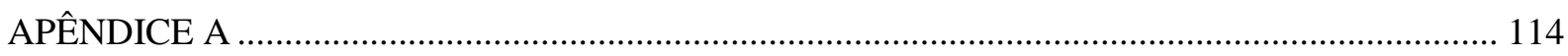

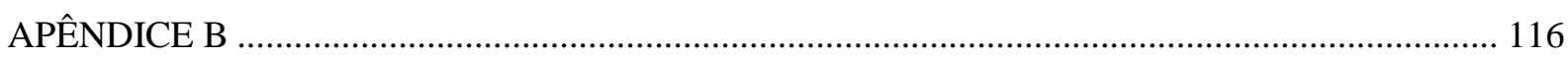

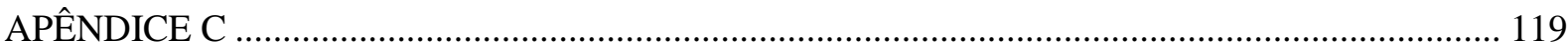

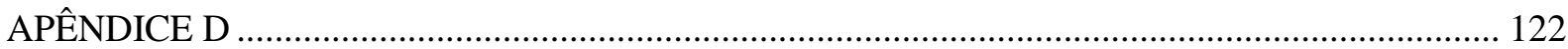

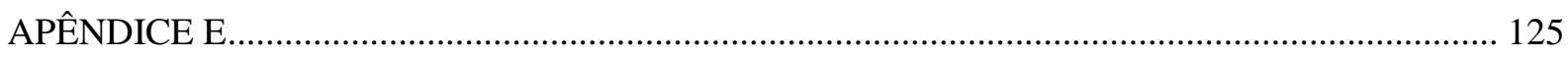

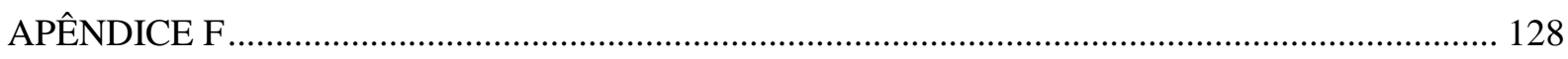




\section{INTRODUÇÃO}

As organizações públicas estão sob constante pressão para melhoria de desempenho de forma transparente por meio do monitoramento e controle de resultados. As práticas gerenciais do setor privado têm servido de modelo para as mudanças estratégicas do setor público, porém algumas destas características típicas como: a existência de hierarquias rígidas; mudanças políticas e culturais, impedem a aplicação dos modelos apresentados pelo setor privado e são as principais barreiras encontradas para uma efetiva mudança.

Dentre as organizações públicas estão inseridas as Instituições Públicas de Ensino Superior (IPES) que têm como funções a indissociabilidade do ensino, da pesquisa e da extensão e o atendimento às necessidades da sociedade. A relação universidade-sociedade deve ultrapassar as fronteiras, divulgar ações, serviços, disponibilizar canais de acesso e estimular a participação do exercício da cidadania.

Essas Instituições vêm enfrentando uma realidade desafiante, sendo alvo de questionamentos e reflexões como: a equidade de acesso ao ensino superior; o processo de avaliação institucional; a qualidade tendo como enfoque a gestão universitária; o compromisso com o ensino, a pesquisa e a extensão; a formação profissional e a autonomia universitária. Por isso, a busca pela excelência é um dos caminhos de transformação das IPES na melhoria de processos acadêmicos e administrativos.

As IPES são classificadas como universidades, centros universitários e faculdades pelo Ministério da Educação (BRASIL, 2006). O modelo de estrutura organizacional adotado atualmente pelas universidades públicas continua sendo o burocrático. Segundo Secchi (2009), a estrutura burocrática possui três características fundamentais: a formalidade, que diz respeito aos deveres e responsabilidades dos servidores, formalização entre as comunicações interna e externa e dos processos decisórios; a impessoalidade está presente na relação entre a chefia e seus subordinados, é baseada em funções e linhas de autoridades claras; e o profissionalismo que diz respeito ao valor positivo atribuído ao mérito como critério de justiça e diferenciação. Nesse modelo, as atividades-fim - ensino, pesquisa e extensão - e as atividades-meio - processos administrativos - das universidades públicas estão em graus de importância diferentes de acordo com a melhoria da eficiência na prestação de serviços.

Na década de 80, a New Public Management (NPM) ou Nova Gestão Pública (NGP), segundo Motta (2013, p.84), difundiu-se como "uma nova e promissora modalidade de gestão pública. (...) com o objetivo primordial de fazer a Administração Pública operar como uma 
empresa privada". Surgiu da necessidade de se adotar uma gestão focada em resultado, no desempenho, nos clientes e da substituição de uma estrutura hierárquica e centralizada para uma gestão menos centralizada. Os servidores públicos assumiriam o papel de prestadores de serviço, responsabilizando-se em promover a atividade-fim com maior eficiência; e os cidadãos deixam de ser apenas receptores dos serviços prestados pelo Estado, e passam a ser considerados como clientes e usuários dos serviços públicos.

Com o advento da NPM surgiram novas práticas como: gestão da qualidade; reengenharia: e downsizing, que desencadearam no surgimento da gestão por processos. Por meio dessa pretende-se maximizar os resultados e o desempenho dos processos, permitindo a redução de custos, otimização de recursos e aumento na qualidade dos serviços prestados.

Para a implantação da gestão por processos, criou-se um mecanismo organizacional conhecido como Escritório de Processos (EP), unidade responsável pelo gerenciamento dos processos da organização e que atua como elo de ligação entre os diferentes departamentos envolvidos (PAIM et al., 2009).

Assim como as demais Instituições Públicas de Ensino Superior, a Universidade de Brasília (UnB) tem por finalidade prestar serviço de qualidade nas áreas de ensino, pesquisa e extensão, integrados na formação de cidadãos qualificados para o exercício profissional. Para isso, conforme estabelecido no seu Estatuto (1994), a forma de gestão da UnB deve observar os princípios da gestão democrática, da descentralização e da racionalidade organizacional. Para realizar e tomar decisões a respeito dos processos que circulam pelas unidades acadêmicas e administrativas, a administração superior utiliza-se da gestão burocrática.

A UnB criou, por meio do Ato $\mathrm{n}^{\mathrm{o}}$ 385, de março de 2011, a Diretoria de Processos Organizacionais (DPR) com o objetivo de propor e institucionalizar um modelo de gestão por processos. Inicialmente, foi utilizado como referência o Programa Nacional de Gestão Pública (GESPÚBLICA), criado pelo Governo pelo Decreto 5.383, de 3 de março de 2005. Porém, tendo em vista a falta de apoio da alta administração, servidores e equipamentos, a Diretoria não conseguiu avançar na implantação de um modelo. Somente a partir de 2013, com a mudança da alta direção e da diretoria, fortaleceu-se a visão por processos como sendo o eixo central da Instituição e como forma de garantir que as ações sejam executadas de forma alinhada, otimizadas e com foco.

Dessa forma, questiona-se como a Diretoria de Processos Organizacionais implantou a gestão por processos na Universidade de Brasília (UnB) entre o período de 2011 a 2015? 


\subsection{OBJETIVOS}

\subsubsection{Objetivo Geral}

Apontar aspectos que contribuam com a implantação da Gestão por Processos adotada pela Diretoria de Processos Organizacionais (DPR/UnB).

\subsubsection{Objetivos Específicos}

- Identificar o modelo de Gestão por Processos adotado pela UnB;

- Descrever a implantação da Gestão por Processos adotada pela UnB;

- Demonstrar a importância estratégica da DPR para gestão por processos na UnB;

- Identificar as vantagens para a UnB em adotar a gestão por processos.

\subsection{JUSTIFICATIVA}

A necessidade de organizações públicas de se adequarem aos novos programas de aperfeiçoamento de processos têm se mostrado uma constante nos últimos anos. A gestão por processos, inicialmente desenvolvida no setor privado, tem sido utilizada também no setor público. Nesse setor, a relevância da gestão por processos de negócio é percebida por meio da maior eficácia e eficiência alcançada a partir da reestruturação organizacional, juntamente com os processos multifuncionais (GULLEDGE JR.; SOMMER, 2002).

Segundo Biazzi (2007), no caso específico das Instituições Públicas de Ensino Superior, a iniciativa de se adotar uma visão por processos, mapeá-los e aperfeiçoá-los resulta em um enorme benefício administrativo, sendo o Escritório de Processos a unidade responsável pelos métodos e ferramentas que orientam o gerenciamento dos processos da Instituição. A visão sistêmica desse escritório em relação aos processos da organização permite uma análise mais eficaz, gerando e coordenando sugestões de melhoria que beneficiem um dado processo como um todo.

Diante desse contexto, para que haja entendimento e melhoria dos fluxos de trabalho na gestão da UnB e efetividade na implantação da gestão por processos na Universidade de Brasília, surge a necessidade de analisar como a Diretoria de Processos Organizacionais implantou a gestão por processos na Universidade no período entre 2011 a 2015. Esse estudo permitirá verificar se a prática de gestão por processos no escopo de atuação e na cultura organizacional da Universidade foi alcançado. 


\section{REFERENCIAL TEÓRICO}

\subsection{INSTITUIÇÕES PÚBLICAS NO BRASIL}

Instituições públicas no Brasil apresentam características baseadas no modelo burocrático de Max Weber (1994), quais sejam: formalidade, impessoalidade e profissionalismo. A formalidade diz respeito às normas que estipulam os direitos e deveres dos envolvidos na organização e o modo de funcionamento. $\mathrm{Na}$ impessoalidade, as relações entre as pessoas são governadas de acordo com o cargo que ocupam e os direitos e deveres pertinentes a esse. No profissionalismo, os cargos são ocupados dentro da organização de acordo com a hierarquia que a regem.

A Teoria Burocrática de Max Weber (1994) proporciona uma maior racionalidade sobre os objetivos e ações dos envolvidos na organização, auxiliando na precisão e rapidez das atividades, decisões, deveres e obrigações. Mas também apresenta uma série de desvantagens que são bastante perceptíveis nas nossas instituições, tais como: apego excessivo às normas, que passam a ser consideradas absolutas; regras individuais passam a ser gerais; o trabalho passa a ser feito de modo rotineiro, sem nenhum questionamento do modus operandi, da legislação ou de nenhum outro aspecto envolvido.

É perceptível que Max Weber (1994) não somente iniciou a melhoria nas estruturas organizacionais públicas, como também ofereceu uma contribuição de forma consistente para o desenvolvimento da estrutura administrativa das instituições, ajudando a combater as práticas patrimonialistas que atrasavam o desenvolvimento da administração pública brasileira.

Outra característica particular das instituições públicas brasileiras é a sua cultura. Segundo Carbone (2000), para sobreviver no Brasil, em especial vivendo da máquina pública, sempre foi necessário jogo de cintura, incerteza, amigos influentes, habilidades diplomáticas para não ferir suscetibilidades, paciência, compreensão para com a incompetência alheia e outras coisas do gênero. A referência da boa gestão nunca foi a produtividade ou o empreendedorismo. Em relação à cultura organizacional brasileira, o autor afirma que essa é forte o bastante para desfocar a leitura dos processos e subjugar as mudanças.

Carbone (2000, p. 4) vai um pouco mais além e aponta que "particularmente no setor público brasileiro a cultura interna pode orientar e promover um comportamento de sucesso profissional paradoxalmente distinto daquele necessário para o sucesso organizacional”. O 
que se espera de uma organização que atua num setor de alta competitividade e altamente especializado é que os envolvidos aceitem os comportamentos voltados para o empreendedorismo e a profissionalização permanente. Mas o que se observa é totalmente ao contrário, utiliza-se na organização a cultura brasileira, onde as relações interpessoais são entendidas como algo mais importante do que as normas e a ordem estabelecida, o cliente não é a prioridade, e sim o chefe, aquele que garante emprego.

Junquilho (2004) buscou mostrar a complexidade de mudança na forma de agir dos denominados administradores burocráticos demonstrando, por meio de uma pesquisa, que suas ações refletem práticas cotidianas construídas a partir de um processo histórico-social, compreendendo a dimensão cultural, ou seja, traços inerentes à cultura brasileira que influenciam as ações desses atores no interior das organizações públicas.

A pesquisa foi realizada nas Secretarias de governo de um estado localizado na Região Sudeste, escolhidas por terem vivenciado, no período de janeiro de 1995 a dezembro de 1998, experiências ancoradas na implantação de pressupostos da chamada administração pública gerencial. O universo da pesquisa empírica foi formado por servidores que exerciam função gerencial por um tempo mínimo de dois anos, a partir de janeiro de 1995. Os ocupantes de função gerencial foram divididos em três níveis: alta gerência (AG) - chefes de gabinete e subsecretários; gerência intermediaria (GI) - superintendentes, coordenadores e subcoordenadores; gerência de linha (GL) - chefias de grupos setoriais e de departamento. Apenas 77 servidores correspondiam aos pré-requisitos, definindo, assim, a amostra como não-probabilística, atingindo representantes de todas as secretarias. A coleta de dados foi realizada por meio de entrevistas com roteiro semi-estruturado e o tratamento dos dados apoiou-se na concepção da análise de conteúdo.

Dessa forma, Junquilho (2004) chegou à conclusão que o contexto sociocultural brasileiro condiciona a ação de ocupantes de posições de chefias nas diversas secretarias pesquisadas, o que permitiu relacionar um conjunto de práticas ancoradas na realidade cultural brasileira que são utilizadas nas organizações, tais como: a boa vizinhança - os gerentes, tendo em vista a falta de cooperação entre as unidades organizacionais, desenvolvem relações pessoais e amizades para facilitar o convívio profissional; o sincretismo casa/rua - pois as organizações são vistas como uma segunda casa para os gerentes e, paralelamente, como um local de conflitos e de definição de estratégias pelas quais lutam para a sobrevivência nos cargos; o controle cordial - o uso de relações afetuosas com o objetivo de evitar situações de conflito direto, pois há uma dificuldade em aplicar regras impessoais na punição de insubordinados; a contemporização - tolerância diária na organização é habitual, 
gerando atitudes de acomodação, condescendência e não-enfrentamento de conflitos diretos, originando o "jogo de cintura"; o plantador de coco - metáfora utilizada para comparar os gerentes e governantes públicos a plantadores de coco, onde os bons frutos devem ser colhidos a curto prazo, imperando o conhecido "apaga incêndio" tendo em vista a falta de planejamento das atividades cotidianas; o faz-de-conta - prática que não privilegia as avaliações formais de desempenho, vigorando a informalidade; o manda-chuva - a velha expressão "manda quem pode, obedece quem tem juízo", centralização e autoritarismo no topo da hierarquia; odar a volta por cima - o famoso uso do "jeitinho" para convívio com o excesso de normas e decretos formais, caracterizado pelas relações pessoais como facilitador na solução de dificuldades em se obter resultados pelos caminhos formais.Diante desse contexto, o autor conclui que "essas práticas não podem ser vistas como regra absoluta nos setores públicos brasileiro, pois a cultura brasileira não é homogênea, assim como o próprio conceito de cultura".

A administração pública brasileira apresenta-se em três níveis de governo - federal, estadual e municipal -, cada um dotado de especificidades e práticas gerenciais distintas. Além disso, no que diz respeito ao nível organizacional, divide-se entre administração direta os serviços são prestados pelos próprios entes - e indireta - entidades criadas para atuar em nome do governo, dispondo de autonomia e mandamentos legais diferenciados.

Dentro dessa perspectiva, Junquilho (2004) propôs a caracterização de um tipo ideal de perfil gerencial denominado gerente caboclo que configura um hibridismo entre os tipos ideais do burocrata weberiano e o novo gerente - concebido na administração pública gerencial, apresentada no Plano Diretor da Reforma do Estado por Bresser-Pereira.

Cada instituição pública possui especificidades e práticas cotidianas que irão apresentar por muitas vezes traços do perfil burocrático weberiano com traços do novo gerente. O gerente caboclo foi criado com características culturais da organização estudada e pretendeu servir como referência da importância de saber ler e interpretar distintas realidade e seus significados, oriundos das subjetividades de seus atores sociais. Portanto, todas as características aqui apresentadas (burocracia, estrutura etc) devem ser levadas a priori na execução de projetos de mudança ou programas de melhoria para que não hajam falhas. Os modelos de aperfeiçoamento devem ser adaptados ao contexto das instituições públicas.

De acordo com Bresser Pereira (1996), o Brasil passou por três reformas da administração pública. Em 1936, ocorreu a primeira reforma chamada de burocrática. A segunda, de 1967 que foi um ensaio de descentralização e de desburocratização e, por ter sido revertida, nem sempre é considerada como reforma. E a terceira reforma, proposta por 
Fernando Henrique Cardoso em 1995, apoiada na administração pública gerencial, em resposta à grande crise do Estado dos anos 80 e à globalização da economia.

A primeira reforma administrativa, da administração burocrática clássica foi promovida no Brasil, em 1936, por meio da criação do Departamento Administrativo do Serviço Público (DASP) e da afirmação dos princípios centralizadores e hierárquicos da burocracia clássica. Essa administração foi adotada para substituir a administração patrimonialista na qual o patrimônio público e privado eram confundidos. Porém, como afirma Bresser Pereira (1996, p.5), “a administração burocrática é lenta, cara, auto-referida, pouco ou nada orientada para o atendimento das demandas dos cidadãos”.

No final dos anos 60, ocorre o que Bresser Pereira (1996, p. 6) considera como "a primeira tentativa de reforma gerencial da administração pública brasileira", a publicação do Decreto-Lei $\mathrm{n}^{0}$ 200, de 25 de fevereiro de 1967, que dispõe sobre a organização da administração federal e estabelece diretrizes para a reforma administrativa. Esse decreto deu ênfase à descentralização mediante a autonomia da administração indireta, instituiu princípios do planejamento e do orçamento e do controle dos resultados. Porém, algumas práticas foram consideradas patrimonialistas, como a contratação de empregados sem concurso público, e outras burocráticas, por não se preocupar com mudanças no âmbito da administração direta ou central. Assim, essa reforma administrativa não se concluiu e fracassou.

A transição entre a eleição de Tancredo Neves e a posse de José Sarney, em março de 1985, não apresentou características de reforma do aparelho do Estado. Em 1988, a Constituição Federal é promulgada, sacramentando, conforme Bresser Pereira (1996), os princípios de uma administração pública arcaica, burocrática ao extremo. Uma administração pública altamente centralizada, hierárquica e rígida, em que toda a prioridade será dada à administração direta ao invés da indireta. A promulgação da Constituição foi considerada um retrocesso burocrático por Bresser (1996) por ser uma reação ao clientelismo e uma afirmação de privilégios corporativistas e patrimonialistas incompatíveis com a burocracia.

Em 1990, houve o episódio da hiperinflação no final do governo Sarney (19851990), fazendo com que a sociedade passasse a se preocupar com a crise fiscal e a crise do modo de intervenção do Estado. No governo Collor (1990-1992), ocorreu a abertura comercial, a privatização ganhou impulso e o ajuste fiscal avançou de forma decisiva. Entretanto, a reforma na administração pública, nesse período, fracassou. Houve uma tentativa de reduzir o aparelho do Estado, demitindo funcionários e eliminando órgãos, desorganizando a estrutura burocrática existente e desprestigiando os servidores públicos. 
A sociedade começou a se preocupar com a crise na administração pública no governo Itamar (1992-1994). Um estudo realizado pelo Centro de Estudos de Cultura Contemporânea (CEDEC) para a Escola Nacional de Administração Pública (ENAP) gerou um importante diagnóstico a respeito da crise administrativa. $\mathrm{O}$ documento afirmava que o mal maior a ser atacado era o intenso e generalizado patrimonialismo no sistema político; e o objetivo fundamental a ser atingido, o de estabelecer uma administração pública burocrática. A esse respeito, ainda de acordo com Bresser Pereira (1996, p. 12), "ao reafirmar valores burocráticos clássicos, o documento não se dava conta que inviabilizava os objetivos a que se propunha”. Desse modo, não se dava conta da necessidade de uma modernização radical da administração pública.

A partir de 1995, com o governo Fernando Henrique (1995-2002), surge uma oportunidade para a reforma do Estado, principalmente, do aparelho do Estado e do seu pessoal. Foi criado o Ministério da Administração Federal e Reforma do Estado (MARE) em substituição à Secretaria da Administração Federal da Presidência da República, que tinha como missão implementar a reforma gerencial, usando como instrumentos básicos o orçamento anual da República e, em especial, o Plano Plurianual (PPA).

A reforma do Estado brasileiro deflagrada em 1995 teve como objetivo - tendo parte integrante a reforma administrativa - manter equilibradas as contas públicas e, ao mesmo tempo, elevar a capacidade da ação estatal. A reforma propõe uma reconfiguração das estruturas estatais baseada na substituição do modelo burocrático de administração pública por um modelo gerencial. A reforma constitucional foi parte fundamental da reforma gerencial, já que mudou as instituições normativas fundamentais. Mudanças institucionais, porém, foram de caráter infraconstitucional. Como, por exemplo, a criação das agências executivas e as organizações sociais.

O MARE elaborou, no primeiro semestre de 1995, o Plano Diretor da Reforma do Aparelho do Estado e a emenda constitucional da reforma administrativa, tomando como base as experiências de países da Organização para a Cooperação e Desenvolvimento Econômico (OCDE), como Grã-Bretanha, Nova Zelândia, Austrália, todos os países escandinavos, Estados Unidos e Chile. Nesses países a reforma administrativa ficou conhecida como New Public Management (NPM) ou Nova Gestão Pública (NGP) ou Nova Administração Pública (NAP). Esse documento, além de constatar a ineficiência do serviço público existente no Brasil, procurou definir as instituições e estabelecer as diretrizes para a implantação de uma administração pública gerencial. 
A Reforma Gerencial de 1995, de acordo com Bresser (1999), pretendia: a descentralização dos serviços sociais para estados e municípios; a delimitação mais precisa da área de atuação do Estado; a distinção entre as atividades do núcleo estratégico e as atividades de serviços; a formulação de políticas e sua execução; maior autonomia para as atividades executivas exclusivas do Estado que adotarão a forma de agências executivas; maior autonomia ainda para os serviços sociais e científicos que o Estado presta, que deverão ser transferidos para "organizações sociais"; assegurar a responsabilização (accountability) através da administração por objetivos, da criação de quase-mercados, e de vários mecanismos de democracia direta ou de controle social, combinados com o aumento da transparência no serviço público, reduzindo-se concomitantemente o papel da definição detalhada de procedimentos e da auditoria ou controle interno - os controles clássicos da administração pública burocrática - que devem ter um peso menor. Características essenciais para a reforma do Estado Brasileiro como a privatização de empresas estatais que produzem bens e serviços e a terceirização de atividades de apoio também estavam previstas no Plano Diretor.

Dentro do contexto da reforma gerencial, a gestão pela qualidade total ganhou vida nova. O controle de qualidade na administração pública ganhou legitimidade e tornou-se estratégia gerencial oficial para a implantação da reforma. Desse modo, foi criado o Programa de Qualidade e Participação na Administração Pública (PBQP) como principal instrumento para a mudança de uma cultura burocrática para uma cultura gerencial, responsável por promover a revolução nos valores estabelecidos no plano político-filosófico, necessários à implementação de um novo modelo de Estado: participação, reconhecimento do potencial do servidor e de sua importância no processo produtivo, igualdade de oportunidades e a opção pela cidadania; estando associado aos processos educacionais que conduzem a uma renovada visão do mundo (BRASIL, 1997).

A estratégia de atuação do programa, no período entre 1995 a 1998, foi modificada. Segundo Lima (2013), o PBQP reorientou sua forma de agir, saiu da ênfase nas técnicas e ferramentas e passou a trabalhar objetivamente na dimensão institucional. $O$ foco, que a princípio era nos servidores e processos, passou para as organizações e seu sistema de gestão. Em 1999, o programa é fortemente impactado pela extinção do MARE, havendo baixa adesão por parte das organizações públicas.

Em 2000, o programa muda seu nome para Programa de Qualidade do Serviço Público (PQSP) com o intuito de ser mais coerente com a ideia de um programa geral para a administração pública e de um instrumento de orientação do setor público para o seu ambiente 
externo. Apesar de um avanço nas adesões e representação nos Estados, no final de 2001, o PQSP sofreu algumas ameaças de acordo com Lima (2013): rejeição ostensiva à autoavaliação; rejeição à dimensão nacional do programa; e dispensa dos servidores envolvidos no programa e obstrução à realização de cerimônias anuais do Prêmio Nacional de Gestão Pública. Pode-se dizer que o PQSP ficou estagnado até 2005, quando houve sua restruturação por meio do Decreto $\mathrm{n}^{0} 5378$, de 23 de fevereiro de 2005, o qual instituiu o Programa Nacional de Gestão Pública e Desburocratização - GESPÚBLICA (BRASIL, 2005).

Para auxiliar qualquer organização pública, interessada em simplificar seus processos e normas, eliminando exigências de rotinas que geram fluxos desconexos na tramitação de documentos que não agregam valor ao serviço prestado pela organização e, por consequência, pelo Estado, foi elaborado o Guia "d" Simplificação Administrativa. Esse Guia deve ser entendido como uma ferramenta de trabalho, eminentemente prática, para realizar a análise e melhoria de processos organizacionais. É uma ferramenta de trabalho, eminentemente prática, para realizar a análise e melhoria de processos organizacionais. O documento está organizado em uma sequência lógica de dez passos, subdivididos em quatro grandes etapas: planejamento da simplificação; mapeamento do processo; análise e melhoria dos processos; e implementação das melhorias (conforme informações que constam no sítio do Gespública na internet: https://conteudo.gespublica.gov.br).

O programa GESPÚBLICA (BRASIL, 2005) disponibiliza tecnologias de gestão capazes de estimular e promover melhoria continuada de processos gerenciais. Além do Guia “d” Simplificação, encontra-se o Guia de Gestão de Processos, instrumento que orienta a modelagem e a gestão de processos voltados ao alcance de resultados. A descrição envolve a reflexão acerca de características de validade dos produtos e serviços prestados, de referências (normas e conhecimentos) observadas, de recursos consumidos e dos insumos necessários à tomada de decisão com qualidade pelas pessoas e pelas instituições públicas (conforme sítio do Gespública na internet: https://conteudo.gespublica.gov.br).

O GESPÚBLICA (BRASIL, 2014) é, em síntese, um novo modelo de gestão, cujo propósito é contribuir para a qualidade dos serviços e para a geração de ganhos sociais. Seu centro prático de ação é o processo, o qual é entendido pelo programa como um conjunto de atividades inter-relacionadas ou interativas que transforma insumos em produtos/serviços com alto valor agregado. Foi a partir desse entendimento que a gestão baseada em processos ganhou enfoque para uma gestão pública de excelência. Sendo assim, faz-se necessária a 
conceituação de processo, seus tipos e classificação para que se possa, enfim, chegar ao modelo de gestão por processos pretendido.

\subsection{PROCESSO}

Introduzindo o conceito de processo, Biazzi, Muscat e Biazzi (2011, p.871) afirmam que “(...) é uma ordenação específica das atividades de trabalho no tempo e no espaço, com um começo, um fim, entradas e saídas, claramente identificadas”, conforme a Figura 1.

Figura 1 - Representação de processo.

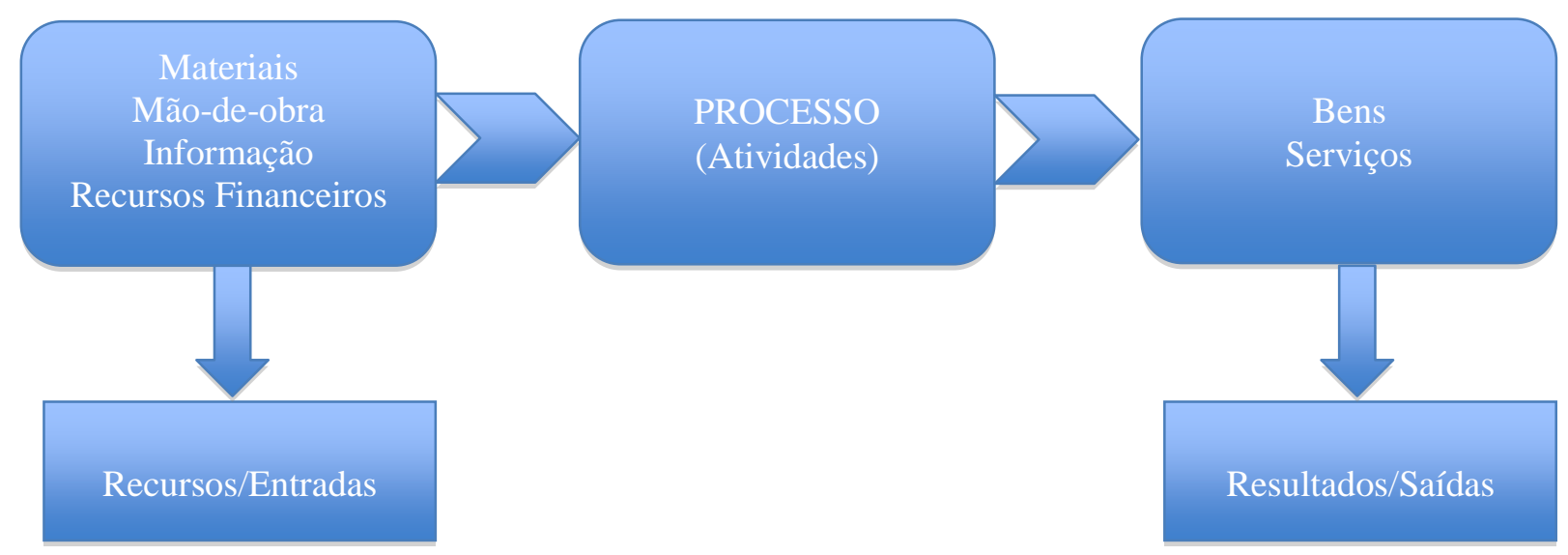

Fonte: Biazzi, Muscat e Biazzi (2011, p. 871).

Essa definiçãa oriunda da engenharia e, portanto, é relacionada a atividades que são mais interdependentes e realizadas numa sequência específica. Por ser uma definição muito restrita, não abrange processos que não têm início e fim claros ou cujo fluxo não é bem claro. Alguns processos podem ter impacto maior do que os demais na própria viabilidade da organização. Sendo assim, muitos autores a partir da década de 90 buscaram outros conceitos do que é processo.

Davenport (1994, p. 13), um dos primeiros autores sobre reengenharia de processos, propôs que:

um processo é simplesmente um conjunto de atividades estruturadas e medidas, destinadas a resultar num produto especificado para um determinado cliente ou mercado. É, portanto, uma ordenação específica das atividades de trabalho no tempo e no espaço, com um começo, um fim e inputs e outputs claramente identificados: uma estrutura para a ação. Enquanto a estrutura hierárquica é, tipicamente uma visão fragmentada e estanque das responsabilidades e das relações de subordinação, a estrutura de processo é uma visão dinâmica da forma como a organização produz valor. 
Para Paim (2002), processos são uma estruturação-coordenação-disposição lógicotemporal de ações e recursos que têm por objetivo gerar produtos/serviços para os clientes da organização. Esses podem estar relacionados a qualquer atividade, finalística ou de apoio, possuindo um responsável pelo desempenho global e outros locais direcionados ao andamento de suas partes constituintes. O desenrolar e odesenvolvimento dos fluxos de objetos cabem aos processos, enquanto às funções ou unidades cabe a concentração de conhecimentos por semelhança dentro das organizações.

Para Salerno (1999, p. 105), processo é definido como:

uma cooperação de atividades distintas para a realização de um objetivo global, orientado ao cliente final que lhes é comum. Um processo é repetido de maneira recorrente dentro da empresa. A um processo correspondem: um desempenho, que formaliza o seu objetivo global (um nível de qualidade, um prazo de entrega etc.); uma organização que materializa e estrutura transversalmente a interdependência das atividades do processo, durante sua duração; uma co-responsabilidade dos atores nesta organização, com relação ao desempenho global; uma responsabilidade local de cada grupo de atores ao nível de sua própria atividade.

Processos transformam entradas em saídas de acordo com certas regras e restrições, e são habilitados por diversas pessoas, sistemas e instalações. Existem para entregar valor aos clientes e outras partes interessadas, não existindo de forma isolada. A saída de um é sempre a entrada de outro. Operam em ecossistema multifacetado e não são compostos apenas de sequências de atividades simples. Nessa visão, questões externas (satisfação do cliente, níveis de serviço, qualidade, reutilização etc.) fazem parte do gerenciamento bem como questões internas: identificação de perdas, redução de tempo do ciclo, simplificação de regras.

Seja qual for seu ramo de atividade, são os processos que permitem que o trabalho se realize, assim, independentemente da eficiência da organização ou de seus funcionários, se os usados já estão superados, sua sobrevivência estará seriamente comprometida. É importante que os envolvidos o entendam de forma mais detalhada possível a fim de melhorá-los continuamente.

Tendo em vista a utilização da palavra processo em diversas áreas e atividades do cotidiano, torna-se necessário conceituar alguns termos básicos utilizados na literatura que são relacionados à processo e que proporcionarão um melhor entendimento, conforme Quadro 1.

Quadro 1 - Conceitos básicos

\begin{tabular}{|l|l|}
\hline \multicolumn{1}{|c|}{ Termo } & \multicolumn{1}{|c|}{ Conceito } \\
\hline $\begin{array}{l}\text { BPM (Business Process } \\
\text { Management) }\end{array}$ & $\begin{array}{l}\text { É uma abordagem disciplinada para identificar, desenhar, executar, } \\
\text { documentar, implantar, medir, monitorar, controlar e melhorar } \\
\text { processos de negócio com o objetivo de alcançar resultados } \\
\text { consistentes e alinhados com as estratégias de uma organização. }\end{array}$ \\
\hline
\end{tabular}




\begin{tabular}{|c|c|}
\hline Macroprocesso & $\begin{array}{l}\text { Processo que geralmente envolve mais de uma função da } \\
\text { organização, cuja operação tem impactos significativos nas demais } \\
\text { funções. Normalmente é o maior nível na estrutura de processos } \\
\text { dentro de uma organização. }\end{array}$ \\
\hline Processo & $\begin{array}{l}\text { Sequência de atividades inter-relacionadas que recebe entradas, } \\
\text { agrega-lhes valor e as transforma em saídas. Têm início e fim bem } \\
\text { determinados. }\end{array}$ \\
\hline Subprocesso & $\begin{array}{l}\text { Processo embutido em outro processo, em um nível maior de } \\
\text { detalhamento, podendo ser subdividido em atividades de menor } \\
\text { nível. }\end{array}$ \\
\hline Atividades & $\begin{array}{l}\text { Todo trabalho que é executado em uma organização. É a ação } \\
\text { executada que tem por finalidade dar suporte aos objetivos da } \\
\text { organização. Correspondem ao "o quê" é feito e "como" é feito } \\
\text { durante o processo }\end{array}$ \\
\hline Tarefa & $\begin{array}{l}\text { É uma atividade elementar do último nível de decomposição de um } \\
\text { processo. }\end{array}$ \\
\hline Modelagem de Processo & $\begin{array}{l}\text { É um conjunto de atividades envolvidas na criação de } \\
\text { representações de um processo de negócio. Ela provê uma } \\
\text { perspectiva ponta-a-ponta dos processos de uma organização. } \\
\text { Objetiva criar modelos de processo. }\end{array}$ \\
\hline
\end{tabular}

Fonte: Adaptado pelo autor, adaptado de Baldam, Valle e Rozenfeld (2014).

Para uma visualização a respeito dos processos, torna-se importante diferenciá-los da produção de bens e serviços dos relacionados com a gestão de organizações. Conforme apresentado no Quadro 2, Paim et al. (2009, p. 104) afirmam que:

além dos elementos centrais, existem alguns atributos que contribuem para o entendimento do processo, sua classificação e criam implicações gerenciais. Esses foram divididos em coordenação, complexidade de atributos, tipo de propósito, criticidade/importância, maturidade e capacitação.

Quadro 2 - Atributos do Processo

\begin{tabular}{|c|c|c|}
\hline ATRIBUTOS & FINALIDADE & FORMAS/CLASSIFICAÇÃO \\
\hline Coordenação & $\begin{array}{l}\text { Integrar as atividades desenvolvidas em } \\
\text { cada área da organização. }\end{array}$ & $\begin{array}{l}\text { Lateral, como redes interpessoais; } \\
\text { Informal, que envolve comunicação } \\
\text { formal ou informal; } \\
\text { Formal, envolve equipes, } \\
\text { coordenadores e estruturas matriciais; } \\
\text { Estruturação flexível ou rígida; } \\
\text { centralizada ou descentralizada; }\end{array}$ \\
\hline $\begin{array}{c}\text { Complexidade } \\
\text { de } \\
\text { Atributos }\end{array}$ & $\begin{array}{l}\text { Complementar a descrição do processo na } \\
\text { forma de modelos que representam mais } \\
\text { do que atividades, recursos e objetos em } \\
\text { fluxo. Varia em função da natureza das } \\
\text { atividades predominantes em um processo. }\end{array}$ & 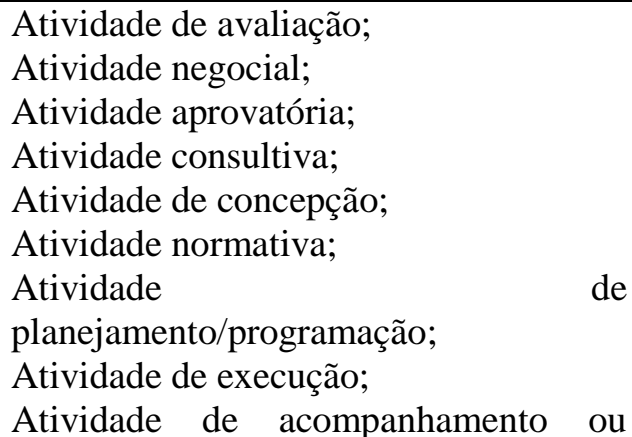 \\
\hline
\end{tabular}




\begin{tabular}{|c|c|c|}
\hline & & $\begin{array}{l}\text { monitoramento; } \\
\text { Atividade de controle. }\end{array}$ \\
\hline $\begin{array}{l}\text { Tipo de } \\
\text { Propósito }\end{array}$ & $\begin{array}{l}\text { Gerenciar, transformar/produzir um } \\
\text { produto ou dar suporte a outros } \\
\text { processos. }\end{array}$ & $\begin{array}{l}\text { Processos de gestão; } \\
\text { Processos finalísticos; } \\
\text { Processos de suporte ou apoio. }\end{array}$ \\
\hline $\begin{array}{l}\text { Criticidade } \\
\text { ou } \\
\text { Importância }\end{array}$ & $\begin{array}{l}\text { Relacionada à contribuição para } \\
\text { agregação de valor, à transformação ou } \\
\text { à contribuição para a transformação do } \\
\text { produto que resulte em percepçâo pelo } \\
\text { cliente e, principalmente, relacionada à } \\
\text { orientação dos critérios para priorizar } \\
\text { processos a serem geridos com maior } \\
\text { atenção. }\end{array}$ & $\begin{array}{l}\text { Críticos; } \\
\text { Não críticos. }\end{array}$ \\
\hline Maturidade & $\begin{array}{l}\text { Relacionada aos típicos níveis de } \\
\text { maturidade - indefinidos, repetitivos, } \\
\text { normatizados, mensurados e geridos. }\end{array}$ & $\begin{array}{l}\text { Processos ad hoc; } \\
\text { Processos repetitivos; } \\
\text { Processos normatizados; } \\
\text { Processos mensurados; } \\
\text { Processos geridos. }\end{array}$ \\
\hline Capacitação & $\begin{array}{l}\text { Relacionada com a capacidade para } \\
\text { entregar o prometido. }\end{array}$ & $\begin{array}{l}\text { Incapaz; } \\
\text { Capaz caso a caso; } \\
\text { Capaz para a organização como um } \\
\text { todo; } \\
\text { Capaz de aumentar valor entregue } \\
\text { continuamente }\end{array}$ \\
\hline
\end{tabular}

Fonte: Elaborado pelo autor.

Gonçalves (2000) dividiu os processos em três categorias a seguir. Processos de negócios ou clientes são considerados primários, pois possuem a capacidade de gerar valor diretamente ao cliente. Caracterizam-se pela atuação da organização e são suportados por outros processos internos, resultando no produto ou serviço que é recebido externamente. Possuem características típicas de organizações, as quais se encontram e são muito diferentes de uma para outra.

Os processos organizacionais ou de integração organizacional são centralizados e viabilizam o funcionamento coordenado dos vários subsistemas da organização em busca de seu desempenho geral, garantindo o suporte adequado aos processos de negócio. Geralmente produzem resultados imperceptíveis para os clientes externos, mas são essenciais para a gestão efetiva do negócio. Usualmente são horizontais, ou seja, criados para a coordenação das atividades que se espalham por várias unidades e de suporte, pois garantem o apoio necessário ao funcionamento adequado dos processos primários ou de negócios.

O processo gerencial típico de organizações é a avaliação da qualidade do atendimento feita pelos clientes. São focalizados nos gerentes e suas relações, incluem as ações de medição e ajuste de desempenho da organização. Conforme Gonçalves (2000), assim 
como os organizacionais, são considerados de informação, decisão e suporte. Podem ser: verticais, ao se referir ao planejamento e orçamento, relacionando-se com a alocação de recursos escassos; ou horizontais, quando têm, como base em seu desenho, o fluxo de trabalho.

Essa categorização, segundo Gonçalves (2000), torna-se essencial para um melhor entendimento dos processos e suas implicações, pois, cada vez mais, as organizações estão preocupadas em agregar valor, construir um ambiente colaborativo, estimular os funcionários e implementar ideias de melhoria e inovação.

Os processos apresentam duas características importantes. Segundo Gonçalves (2000), a primeira é a interfuncionalidade, pois a maioria dos processos atravessa as fronteiras das áreas funcionais, são transversais, transorganizacionais, interfuncionais ou interdepartamentais. Também podem ser chamados de processos horizontais, uma vez que se desenvolvem de maneira perpendicular à estrutura vertical típica das organizações funcionais. Quanto à segunda, refere-se ao fato de que as organizações são uma coleção dos fluxos de valor voltados para a satisfação de clientes internos ou externos.

Segundo Baldam, Valle e Rozenfeld (2014, p. 5),

o termo 'processo de negócio' tomou força no setor de serviços, como
paralelismo aos 'processos de fabricação' usado nas operaços que
envolvem produtos materiais. Nos setores financeiro, de telecomunicações e
de consultoria fala-se livremente em 'processo de negócio' para deixar claro
que se trata dos processos que compõem a atividade fim.

Para Davenport (1994), os processos de negócio de uma organização podem ser considerados como o coração do negócio, propiciando sincronismo e alinhamento entre pessoas, estratégia e tecnologia. Fazem com que as estratégias sejam executadas e monitoradas, ajustadas, caso necessário, até atingirem o que foi planejado. A gestão desses, segundo Dixon (2012), passa a ser denominada de gestão por processos, que é um dos principais alavancadores das organizações públicas que devem se adaptar às frequentes mudanças impostas por leis, legislações, normas etc., o que permite maior agilidade e eficiência na sua prestação de serviços.

Gonçalves (2000) destaca que a ênfase - anteriormente dada aos departamentos da estrutura e às tarefas isoladas - migrou para um modelo organizacional mais simples e dinâmico: a visão centrada em processos. A orientação para os processos do negócio possibilita que a organização seja vista não como um conjunto de departamentos estanques mas, sim, como um fluxo contínuo de atividades encadeadas que começam e terminam no 
cliente. Entender como os processos funcionam e quais são os tipos existentes em uma organização é importante para determinar como eles devem ser gerenciados para a obtenção do máximo resultado. Tendo em vista o crescente interesse das organizações públicas pela gestão por processos, é necessária, em primeiro lugar, a diferenciação entre a gestão por processos da gestão de processos, para então compreender seu contexto e metodologia.

\subsection{GESTÃO DE PROCESSOS}

O termo 'gestão de processos', conforme De Sordi (2012, p.24),

apresenta-se como um estilo de organização e gerenciamento da operação de empresas; já a gestão por processos possui uma abrangência maior e sua abordagem administrativa é de prioridade, foco e desenvolvimento do processo de negócio.

Apesar de serem semelhantes, possuem significados diferentes, uma vez que 'gestão de processos' está relacionada com a engenharia operacional, oriunda do processo mecanicista derivado da Revolução Industrial, por intermédio da divisão do trabalho em atividades sequenciais objetivando sua mecanização. Nos dias de hoje, costuma ser utilizada pelos profissionais da área de pesquisa operacional para o estudo de operações fabris, e por aqueles que atuam na automação de fluxos de trabalhos.

Jesus e Macieira (2014) afirmam que tanto a 'gestão de processos' como a 'gestão por processos' têm por interesse entender as necessidades de seus clientes e repensar o modo como o trabalho é distribuído ao longo de suas unidades para gerar melhores produtos e serviços. Porém, enquanto a primeira foca em estruturar o gerenciamento do ciclo de vida de um determinado processo, buscando sua evolução constante; a outra pressupõe, além de uma alteração organizacional, uma forma de pensar e agir o negócio de maneira diferente.

Ratificando a importância dessa diferenciação, Baldam, Valle e Rozenfeld (2014, p. 17) afirmam que:

o gerenciamento de processos trata os processos isoladamente, enquanto o gerenciamento por processos os trata segundo uma visão estratégica que gerencia a empresa como um todo, voltando-se para os produtos a serem entregues e os processos necessários para que isso ocorra.

\subsection{GESTÃO POR PROCESSOS}


De acordo com De Sordi (2012), a abordagem administrativa da gestão por processos é também conhecida como abordagem sistêmica para a gestão das organizações, de modo que essa denominação foi baseada e fundamentada na Teoria Geral de Sistemas (TGS).

A TGS surgiu com os trabalhos do biólogo austríaco Ludwig von Bertalanffy, publicados entre 1950 e 1968. O austríaco não concordava com a visão cartesiana do universo, colocando, assim, uma abordagem orgânica da biologia com o objetivo de que a ideia que o organismo é um todo maior que a soma das partes fosse aceita (BERTALANFFY, 2008).

Na administração, conforme De Sordi (2012), a TGS passou a ser aplicada em função da necessidade de uma síntese e maior integração das Teorias Científica e Relações Humanas, Estruturalista e Comportamental. Isso fez com que surgisse uma nova abordagem administrativa: a abordagem sistêmica para gestão das organizações.

Para Morgan (1996), as metáforas do organismo ajudaram os teóricos organizacionais a identificar e a estudar diferentes necessidades das organizações enquanto sistemas abertos, instituindo uma visão mais integrada e harmônica destas por meio da adoção e adaptação de termos e conceitos provenientes das ciências naturais. Sob essa perspectiva, as organizações sociais são interpretadas como subsistemas abertos compostos por indivíduos da sociedade total, em que todos os elementos estão interligados sob forças interatuantes.

Maximiano (2012) explica que, ao contrário da Teoria Clássica em que a estrutura e o controle organizacionais eram rígidos, na TGS a estrutura passa a ser flexível e de livre escolha, ou seja, a estrutura é adaptável às atividades desempenhadas pela organização com o objetivo de manter-se no mercado. Quanto mais flexível a estrutura da organização, melhor será sua adaptação ao ambiente. Dessa forma, passou-se a ter uma nova interpretação sobre as organizações.

Ao ser aplicada na administração, foi tratada como uma abordagem sistêmica para a gestão das organizações e implementou alguns termos como: organização funcional, para descrever a organização que utiliza a estrutura funcional; e gestão funcional, quando os conceitos de TGS são aplicados na gestão das organizações.

Conforme De Sordi (2012), a TGS constitui a base para a elaboração da teoria sobre o gerenciamento de processos organizacionais ao enfatizar a necessidade da integração e explicitar a interdependência entre as diferentes partes da organização em detrimento de uma estrutura baseada em silos funcionais. Hammer (2004) denominava os departamentos de 'silos funcionais', e considerava que as inovações não deveriam ficar limitadas a esses, mas desenvolver todos os processos, de uma ponta a outra, passando por todos os departamentos, 
com uma cadeia de atividades coordenadas e gerenciadas. Nessa mesma linha de pensamento, Gonçalves (2000, p.14) afirma que, na organização por funções, “(...) os processos precisam atravessar as fronteiras entre as 'chaminés funcionais', com sensível perda de tempo, qualidade e capacidade de atendimento". Tal visão corrobora a perspectiva da gestão por processos, que torna a integração intra e interorganizacionais fatores importantes para o alcance de diferenciais frente à concorrência.

Baldam, Valle e Rozenfeld (2007, p.7) apresentam de maneira simplificada o entendimento ao abordar a gestão por processos:

\begin{abstract}
A evolução e a difusão da gestão por processos traz a perspectiva das organizações como um conjunto de processos internos e externos que devem ser entendidos e mapeados, de modo que as tarefas não sejam definidas segundo a função dos departamentos organizacionais, mas, sim, de acordo com as atividades que proporcionarão maior valor agregado à organização e aos produtos/serviços oferecidos. Assim, a racionalização contemporânea do trabalho passa a interpretar as atividades organizacionaisde maneira ampla e transfuncional, de forma que um processo pode cruzar departamentos e solicitar diferentes serviços, com foco na atividade que deve ser executada.
\end{abstract}

De Sordi (2012) apresenta algumas características que diferenciam as abordagens administrativas da organização funcional da por processos. Na primeira, os profissionais possuem um papel definido e delimitado, o treinamento serve para um ajustamento à função especifica desempenhada, a supervisão é feita por níveis hierárquicos superpostos e sua avaliação é feita com base no desempenho individual. A estrutura é hierárquica e departamentalizada; as ferramentas de tecnologia da informação são representadas por sistemas limitados às áreas funcionais para os quais foram desenvolvidos; em relação ao ambiente externo, sua competição é fomentada pela pressão constante sobre clientes e fornecedores. Com isso, o que se percebe é um atrito entre as áreas funcionais, desconfiança entre os profissionais e insegurança no trabalho.

$\mathrm{Na}$ abordagem administrativa, as atividades são complementares, apesar de cada profissional desempenhar uma atividade e papel diferentes de acordo com seu perfil e habilidade, gerando sinergia e interação entre os profissionais. A hierarquia é reduzida; não há um comando e controle, mas uma negociação e colaboração. Não existe a figura do 'chefe' e o treinamento cede lugar ao contínuo processo de capacitação visando o atendimento das competências transdisciplinares adquiridas ao longo do processo. A avaliação não é baseada no desempenho individual do profissional, mas sim no desempenho de cada processo, mantendo uma linha de agregação constante de valor ao trabalho final. Os sistemas de informação são integrados permitindo a intercomunicação entre as áreas funcionais. A 
competição cede lugar à colaboração por meio de parceria de negócios visando o bem comum. Dessa forma, a gestão por processos cria uma expectativa de responsabilidade comum entre as redes colaborativas em relação à transparência de informações, cooperação mútua e confiança.

O modo funcional de sistematizar a organização dá lugar a uma visão horizontalizada com foco no próprio trabalho, identificando os principais elementos a serem executados para que a instituição funcione e cumpra sua missão. A organização horizontal aumenta a eficiência e eficácia dos processos, além da velocidade de resposta ao mercado pelas organizações (LAURINDO; ROTONDARO, 2006). Isso porque, no interior de cada processo, são gerados fatos e dados que, junto com os obtidos externamente à organização, dão origem às informações que auxiliam na tomada de decisão e alimentam a produção de conhecimento, conferindo à organização capacidade necessária para a ação e a inovação (BRASIL, 2009).

Segundo Gonçalves (2000b), apesar de a instituição se organizar por processos, pode estar estruturada de maneira funcional, com unidades funcionais definidas e com chefias determinadas; porém os processos operam na horizontal, ou seja, passam por diversas areas e os funcionários participam de vários processos simultaneamente. À medida que esses assumem a responsabilidade pelos processos e seu funcionamento, a chefia passa a focar na supervisão e capacitação de seus funcionários.

Para Hammer (2004), a mudança de uma organização tradicional para processos é difícil, pois os indivíduos têm que aprender a pensar de uma nova maneira, revigorada e sistêmica, compreendendo melhor o negócio, assumindo mais responsabilidades e trabalhando em equipe. Em síntese, é necessário que haja participação, envolvimento e comprometimento de todos para com os objetivos da organização na busca da satisfação do cliente e do consequente aumento da competitividade em uma sociedade cada vez mais globalizada e dinâmica.

Pradella, Furtado e Kipper (2012, p.6) conceituam a gestão por processos como um “enfoque sistêmico de projetar e melhorar de forma contínua os processos organizacionais, por pessoas devidamente capacitadas e trabalhando em equipe, unindo capacidades tecnológicas e inovadoras, com o objetivo de agregar valor para o cliente". Tendo em vista que os valores agregados passam por transformações ao longo do tempo, os processos têm necessidade de evoluírem ao longo de sua vida com o propósito de manter o cliente satisfeito, acrescenta Fiel Filho (2010).

No Manual de Gestão por Processos do Ministério Público Federal (BRASIL, 2013), a gestão por processos é conceituada como uma abordagem sistemática de gestão que trata de 
processos de negócios como ativos, que potencializam diretamente o desempenho da organização, primando pela excelência organizacional e agilidade nos negócios. Isso envolve a determinação de recursos necessários, monitoramento de desempenho, manutenção e gestão do ciclo de vida do processo. Fatores críticos de sucesso estão relacionados a como mudar as atitudes e perspectivas de pessoas em avaliar o desempenho dos processos das organizações. Permite a análise, definição, execução, monitoramento e administração, incluindo o suporte para a interação entre pessoas e aplicações informatizadas diversas, possibilitando que as regras de negócio da organização, travestidas na forma de processos, sejam criadas e informatizadas pelas próprias áreas de gestão, sem interferência das áreas técnicas. $\mathrm{O}$ propósito desses sistemas é padronizar processos corporativos e ganhar pontos em produtividade e eficiência.

Fatores críticos de sucesso, segundo Rockart (1978), são elementos que, quando executados de maneira correta, permitem a evolução da organização. Provenientes dos objetivos, derivam da missão, visão e valores, tornando-se referências obrigatórias e fundamentais para sobrevivência, competitividade e sucesso. Ao serem negligenciados ou ignorados, se tornam responsáveis pelo fracasso da organização.

Dessa forma, de acordo com Baldam, Valle e Rozenfeld (2014), a gestão por processos também possui fatores críticos para sua implantação, como: apoio da alta direção; estratégias para tratar a gestão de mudanças; capacitação de funcionários; cultura de padronização de processos; alinhamento e investimento em tecnologia de informação; projetos de processo com início e fim; estrutura de orientação por processos bem definida, de maneira clara e objetiva; registrar e divulgar os benefícios e agregação de valor alcançados e o alinhamento estratégico obtido.

Ramos (2011, p. 131) enumerou os fatores críticos na implantação da gestão estratégica de processos da seguinte forma: identificação das necessidades e/ou expectativas dos clientes; conhecimento do ambiente externo; determinação das questões críticas do negócio; criação e divulgação da visão; definição dos responsáveis e identificação dos envolvidos pelos processos; mapeamento e padronização dos processos; criação de indicadores/medidas de desempenho para o processo; identificação das causas dos problemas; estabelecimento de sistemas de recompensa; acompanhamento dos processos em todas as fases pelos responsáveis; agilidade nas decisões; análise criteriosa das mudanças; clareza para os que executam de que sua atividade é estratégica; criação de comitês (equipes) para direcionamento de assuntos estratégicos; definição clara de responsabilidades; eficácia nas comunicações; padronização dos serviços; preparação das pessoas para as mudanças; 
qualificação das pessoas envolvidas com a gestão dos processos; revisão dos processos e implantação de melhoria contínua; existência de um sistema de informação gerencial eficaz; visão sistêmica por parte de todos os envolvidos nos processos; inserção da gestão estratégica dos processos como objetivo no planejamento estratégico e efetiva participação da alta administração; desenvolvimento de cultura organizacional favorável à gestão por processos; e otimização da quantidade de níveis hierárquicos e de departamentalização.

Laurindo e Rotandaro (2015) apresentam alguns objetivos da gestão por processos, como: aumentar o valor do serviço oferecido ao cliente; atuar segundo a estratégia considerada mais relevante para a organização; aumentar sensivelmente a produtividade, com eficiência e eficácia; e simplificar processos, condensando ou eliminando atividades que não acrescentam valor aos clientes.

Para Jesus e Macieira (2014), a gestão por processos em uma organização tem como propósitos: dar conhecimento a todos os envolvidos sobre quais são os principais processos, suas interações e como esses afetam as relações internas e externas; permitir a definição e gestão do orçamento a partir da necessidade dos processos; estabelecer a gestão de pessoas com base em processos; conduzir o uso de tecnologia de informação integrada a processos; proporcionar a definição e o acompanhamento de estratégias a partir de seu impactos nos processos; orientar, acompanhar os projetos e dar sinergia entre eles, a partir da forma como que interferem nos processos; e fornecer uma estrutura para a coordenação de cada processo, com responsabilidade e prestação de contas sobre seu desempenho.

Inúmeras são as vantagens para as organizações, identificadas por Baldam, Valle e Rozenfeld (2014) e Fiel Filho (2011), na adoção da gestão por processos. A primeira delas está relacionada à possibilidade de participação mais ativa dos funcionários, favorecendo a motivação, propiciando uma harmonia organizacional e possibilitando a participação em capacitações. Há coordenação e integração do trabalho entre as diversas áreas funcionais, provendo uma visão sistêmica das atividades. Eliminação de redundâncias e atividades duplicadas, permitindo limitar os desperdícios e prevenir a ocorrência de erros, melhorando o uso de recursos disponíveis. Promove a antecipação e controle das mudanças, agilizando a adaptação ou intervenção futura. Habilita a organização a entender a cadeia de valor e ter seu foco direcionado aos clientes internos e externos, impulsionando positivamente a imagem da organização.

Cruz (2012) relaciona outros benefícios para a organização, entre eles: concentra o foco no que realmente interessa: o trabalho; é uma ferramenta para implementação da estratégia organizacional; confere simplicidade e agilidade às atividades; dota a organização 
de flexibilidade organizacional; facilita a gestão através da identificação de indicadores de desempenho e medição de melhorias nos processos; permite uma visão integrada da organização; instrumentaliza a aplicação de abordagens inovadoras; facilita a gestão do conhecimento organizacional e a gestão de competências.

O Manual de BPM CBOK (2013) afirma que a adoção do gerenciamento de processos de negócio apresenta vantagens para quatro grupos: organização, cliente, gerência e ator do processo. Quando a organização está voltada para a gestão por processos, os responsáveis pelos processos (dono de processos, gerente de processos etc) são identificados, permitindo a manutenção e transformação desses, de forma que, quando os clientes estão insatisfeitos, a tomada de decisão é rápida.

Ao identificar, gerenciar e medir os processos de negócio, encontra-se preparada para as transformações e desafios. Quando a medição do desempenho dos processos é efetiva, há possibilidade de se controlar os custos e a qualidade dos serviços prestados. As atividades são identificadas possibilitando: o gerenciamento das capacidades; avaliação e redução dos custos; e compreensão do negócio, de forma a assegurar a sustentabilidade da organização.

Os benefícios para os clientes, segundo o Manual de BPM CBOK (2013), envolvem a prestação de um serviço de melhor qualidade, por meio da transformação de processos, que atenda às expectativas, gerando satisfação. Os atores, que contribuem para o desenho desses processos, passam a reconhecer o propósito do trabalho desempenhado, dando ênfase às atividades exercidas, agregando valor ao produto final. Além disso, a prática de medição do desempenho do processo permite a correção de desvios, quando necessário, maximizando as vantagens voltadas aos clientes.

Almeida (2002, p. 9) aponta que:

precisamos satisfazer cada vez mais nossos clientes (...). Isso, por sua vez, só ocorrerá se os processos internos - tanto produção, quanto de serviços e de negócio tiverem a qualidade de seu desempenho assegurada pelo corpo funcional da organização. Finalmente, tal qualidade só será atingida, se houver capacitação do pessoal e melhoria das tecnologias utilizadas, incluindo-se aí as condições de trabalho existentes.

Para a gerência, a gestão por processos permite confirmar que as atividades realizadas em um processo agregam valor para a organização, caso esse valor não possa ser mensurado, as atividades são inúteis e devem ser eliminadas. Os gerentes de processos assumem a responsabilidade pela gestão desses diariamente, desenvolvendo maneiras de identificar disfunções e assegurar que as unidades organizacionais estejam integradas para solucioná-las. De acordo com o Manual de BPM CBOK (2013, p. 27), “a abordagem baseada 
em processos destaca as inter-relações entre areas funcionais necessárias para atingir resultados. A visão do processo ajuda a focar as interações e os handoffspossibilitando a melhoria da eficácia em geral".

Para os atores do processo, os benefícios na adoção da gestão por processos envolvem no fato de que: o trabalho realizado será reconhecido; entendimento da interdependência entre as atividades e como elas geram valor aos clientes; a capacitação será ajustada ao ambiente de trabalho; e o conhecimento em relação aos detalhes do processo possibilita a identificação dos recursos necessários em termos quantitativos e qualitativos. $\mathrm{O}$ Manual de BPM CBOK (2013, p. 28) afirma que "todos compreendem a importância de se ter uma força de trabalho motivada e de qualidade, entretanto mesmo os melhores profissionais não conseguem desenvolver seu potencial completo se os processos não forem bem compreendidos ou não operarem da melhor forma".

Laurindo e Rotandaro (2015, p. 34) afirmam que:

apesar das enormes vantagens (...) da aplicação da gestão por processos, sua implementação nem parece ser nem natural nem que acontece sem concentração de esforços. É relevante que o projeto da mudança conte com o apoio da alta direção, tenha um alinhamento com a estratégia competitiva e comece com um planejamento da qualidade das operações.

Alguns empecilhos podem impedir ou prejudicar essa implantação, conforme citam Baldam, Valle e Rozenfeld (2014, p. 79): “incerteza de custos de gerenciamento; falta de informação dos profissionais; falta de metodologias adequadas, deixando tudo a cargo de experimentos descontinuados; não definição de métricas de sucesso; e desinformação quanto às ferramentas".

Filho (2011, p. 18), também especifica alguns fatores impeditivos: "carência de uma cultura automatizada na organização para alterar e simplificar tarefas e processos"; a "falta de tempo' alegada pelos funcionários para não assumir novos compromissos, além dos que já possui; execução de tarefas que não agregam valor; falta de capacitação; funcionários que afirmam que o detalhamento dos processos é muito complexo e trabalhoso; dificuldade em reunir os responsáveis de setores distintos que possuem atividades interdependentes e envolvem um mesmo processo; excesso de especialização que direciona para uma segmentação que dificulta as necessidades de transformação organizacional; e a resistência às mudanças pelos funcionários.

Para Laurindo e Rotondaro (2006), a gestão por processos pode ser entendida como um enfoque de desenvolvimento organizacional que tipicamente objetiva alcançar melhorias 
qualitativas de desempenho na gestão, tomando uma visão objetiva e sistêmica das atividades, estruturas e recursos necessários para cumprir os objetivos críticos do negócio.

\subsection{EVOLUÇÃO DA GESTÃO POR PROCESSOS}

Para se chegar ao cenário atual da gestão por processos nas organizações, alguns movimentos são considerados impulsionadores. Para Baldam (2014), quatro são as gerações de racionalização do trabalho que ampliaram e aperfeiçoaram a ênfase gerencial na visão de processos. Seu início foi com Taylor e Ford, na virada do século XIX para o XX. De acordo com Santos, Silveira e Santos (2011), o modelo de administração criado por Frederick Winslow Taylor, conhecido por Administração Científica, tinha por objetivo uma maior produção do trabalhador, com menos tempo e eliminando os desperdícios. Na tentativa de solucionar o problema da velocidade no encadeamento das tarefas, Henry Ford concebeu a linha de montagem de produção contínua, que fazia uso de esteiras interligadas no processo produtivo.

Para Baldam, Valle e Rozenfeld (2014), a segunda geração começou antes da Segunda Guerra e foi marcada pela Escola de Relações Humanas de Elton Mayo e pela Teoria Comportamental ou Behaviorista de Simon, Argyris, McGregor e Likert. Essa geração é considerada um aprimoramento da primeira geração, pois por meio dela as organizações foram humanizadas e democratizadas, dando ênfase aos fatores humanos.

A terceira geração foi marcada pelo Sistema Toyota de Produção (STP). Segundo Paim et al. (2009), o STP migrou o foco da atenção, que na primeira e segunda gerações era na melhoria de processos, para o processo como um todo, demonstrando a possibilidade de se operar, sistemas produtivos baseados em produção de grande escala, com flexibilidade. $\mathrm{O}$ STP deve ser entendido como um conjunto de princípios e técnicas que evoluíram fortemente atreladas à aplicação prática das ideias de automação, o kanban, o controle de qualidade total, a redução de perdas da produção enxuta, entre outras práticas associadas a um de seus princípios básicos, o just in time.

Segundo Baldam, Valle e Rozenfeld (2014, p.27) “os sistemas integrados de gestão (Enterprise Resource Planning - ERP) já pertencem à quarta geração de racionalização do trabalho". Com eles, "parte significativa do feixe organizacional de processos é modelada, racionalizada e transferida ao software". Para Smith e Fingar (2003), além dos ERPs, fazem parte dessa geração outras técnicas como: Six Sigma, inovação de processos, workflow, custeio baseado em atividades, análise de cadeia de valor, gerenciamento de cadeia de 
suprimentos etc. Baldam, Valle e Rozenfeld (2014) incluem na quarta geração algumas práticas, tais como: Controle de Qualidade Total (TQC), Reengenharia e Gerenciamento de Processos de Negócios (BPM). Essas merecem destaque, pois contribuíram efetivamente para incorporar a visão de processos nas organizações e culminaram para um novo modelo de gestão: a gestão por processos.

Para o Controle de Qualidade Total, Paim et al. (2009, p. 49) afirmam que "um processo é uma sequência de atividades realizadas sobre um objeto de interesse qualquer, interno ou externo. A não preocupação com a transfuncionalidade levou ao surgimento de processos intrafuncionais”. Para a Qualidade Total só existe o cliente externo, aquele que compra e utiliza os produtos gerados pelos processos, e somente ele tem o poder de julgar o valor daquilo que a empresa oferece.

Assim, não existe cliente interno na organização, cabendo ao cliente externo o julgamento da utilidade da organização. Paim et al. (2009) reafirmam o papel fundamental do TQC na evolução da teoria dos processos, tendo em vista que suas práticas apresentaram técnicas de melhorias baseadas em processos, como por exemplo, o ISO 9000 e, no caso do Brasil, o Prêmio Nacional de Qualidade. Segundo Maximiano (2012, p. 452), a Reengenharia criada por Michael Hammer e James Champy, no início da década de 90, "foi um marco para a divulgação da administração de processos e do aprimoramento de processos".

Apresentando duas características importantes, a primeira é a de que a unidade de análise passa a ser qualquer processo de negócio, seja de produção ou administrativo. A segunda, conforme Paim et al. (2009), é a importância dada à tecnologia da informação, os Sistemas Integrados de Gestão (ERP) são considerados como instrumento básico para a eficiência dos processos de negócio. Porém, a Reengenharia apresentou algumas deficiências, e a principal delas foi a promessa de uma solução geral e definitiva na reconstrução das organizações. Segundo Ferreira (2010, p. 34),

\footnotetext{
quando Hammer propôs transferir o centro de referência de sua solução para processos, as intervenções desenhadas passaram a ser sistêmicas, transfuncionais e puderam ser apreendidas, sustentadas e receber evolução. Justamente o que a reengenharia nunca imaginou precisar depois de implantada: evoluir.
}

Por terem uma abordagem integral voltada para os processos de negócios, a Reengenharia e o Gerenciamento de Processos de Negócio (BPM), são, por diversas vezes, confundidos. Porém, na reengenharia o tratamento dispensado aos processos de negócio são apenas um projeto de melhoria estanque no tempo. Segundo Paim et al. (2009), o Gerenciamento de Processos de Negócio (BPM) surge como um grande movimento de 
divulgação da visão de processos e faz com que as transformações das organizações se tornem uma disciplina de administração e engenharia.

O Guia para o Gerenciamento de Processos de Negócio (BPM CBOK, 2013) apresenta a seguinte definição:

\begin{abstract}
Gerenciamento de Processos de Negócio (Business Process Management - BPM) é uma disciplina gerencial que integra estratégias e objetivos de uma organização com expectativas e necessidades de clientes, por meio do foco em processos ponta a ponta. BPM engloba estratégias, objetivos, cultura, estruturas organizacionais, papéis, políticas, métodos e tecnologias para analisar, desenhar, implementar, gerenciar desempenho, transformar e estabelecer a governança de processos.
\end{abstract}

Para Capote (2013), o BPM é uma técnica da gestão por processos que visa gerar a entrega de valor para os clientes. Ao se falar de clientes estão inseridas todas as pessoas que consomem ou utilizam, serviços e produtos, fornecidos por organizações privadas, públicas, com ou sem fins lucrativos. No Manual de BPM CBOK (2013), o BPM deve ser pensado como um método, não apenas de melhoria, mas de transformação de processos, pois permite repensar, inovar e mudar os processos de negócio de uma organização.

Segundo Baldam, Valle e Rozenfeld (2014), independentemente de se utilizar BPM, norma ISO 9000, implantação de um ERP, ou qualquer outra iniciativa que busca a melhoria dos processos, o importante para as organizações está na sua transformação em repensar e otimizar seus processos de negócio.

Para Albuquerque e Rocha (2006, p. 46),

O ideal é que todo projeto de redesenho da organização e dos processos organizacionais seja norteado por uma visão de futuro e por diretrizes estratégicas dela decorrentes. Mas essas definições estratégicas não podem ser estabelecidas subjetivamente, como pura expressão da vontade, nem ser genéricas a ponto de não servir para orientar a definição de objetivos e metas concretas de desempenho.

\title{
2.6 IMPLANTAÇAO DA GESTÃO POR PROCESSOS
}

Várias são as metodologias utilizadas para a implantação da gestão por processos nas organizações, neste trabalho apresentaremos a metodologia de Albuquerque e Rocha (2006), a qual não está voltada apenas para a identificação, redesenho e implantação dos processos críticos das instituições, mas para o sincronismo organizacional que consiste em sincronismo interno, entre as areas e os processos organizacionais, bem como em sincronismo externo, em torno dos clientes (ALBUQUERQUE; ROCHA, 2006).

Segundo Albuquerque e Rocha (2006), por meio do mapa de contexto, é possível, aos dirigentes da organização, identificar mudanças ambientais e rupturas internas, 
possibilitando uma rápida tomada de decisão para a solução dos problemas organizacionais. Sendo assim, é importante o envolvimento da alta administração da instituição, que está passando pelo processo de implantação da gestão por processos, nessa etapa.

As etapas de implantação estão ilustradas conforme Figura 2.

Figura 2: Implantação do sincronismo organizacional através do redesenho dos processos

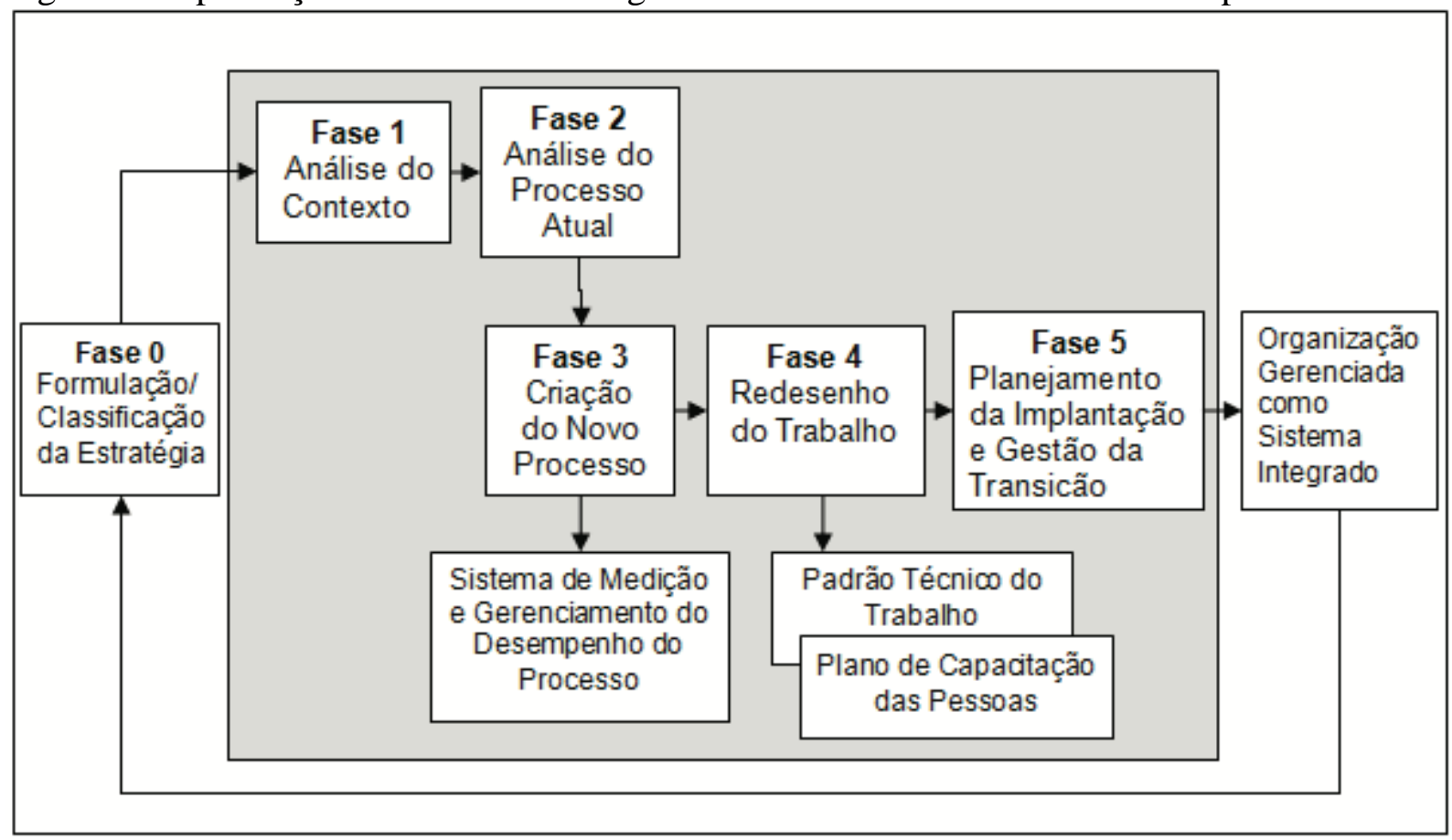

Fonte: Elaborado por Albuquerque e Rocha (2006, p.55).

O modelo possui cinco fases que serão melhor detalhadas conforme Albuquerque e Rocha (2006). A Fase 1, Análise do Contexto Organizacional, permitirá a análise dinâmica da estrutura organizacional, estabelecendo as relações entre as entidades do ambiente externo e de ambiente interno com os processos finalísticos e de apoio. Para tanto, algumas etapas devem ser seguidas, como: mapa de contexto da organização; análise do desempenho atual; estabelecimento de metas para desempenho futuro; identificação das rupturas; seleção dos processos-chave; estabelecimento de metas para melhoria dos processos; e constituição das equipes de redesenho dos processos.

As etapas de análise do desempenho atual e estabelecimento de metas para desempenho futuro, consistem, basicamente, em identificar o desempenho atual da organização por meio das saídas apresentadas (produtos/serviços) para os clientes, e definir metas de desempenho que atendam às necessidades dos clientes. Os problemas identificados na organização e que comprometem o desempenho são denominados de rupturas, pois 
interrompem a interfuncionalidade entre as áreas, acarretando em retrabalho, aumento de custos, esforço desnecessário etc. Albuquerque e Rocha (2006, p.69) identificam:

\begin{abstract}
algumas rupturas mais comuns no nível organizacional: atividades em duplicidade, realizadas por mais de uma área ao mesmo tempo; atividades necessárias que não são realizadas em nenhuma área; indicadores de desempenho centrados na própria área e desalinhados com a missão da organização; indicadores de desempenho puramente funcionais e incoerentes; gargalos que ocasionam aumento de custos e atrasos; e políticas ou normas que prejudicam o desempenho organizacional.
\end{abstract}

Além da identificação das rupturas, Albuquerque e Rocha (2006, p.69) agruparamnas em 3 tipos básicos, argumentando acerca de: "algo que existe mas não deveria existir, pois não agrega valor; algo que não existe mas deveria existir, pois agregaria valor; e algo que existe, deveria existir, mas atualmente, em vez de agregar valor é um problema, pois não funciona a contento". Por 'algo' deve-se entender atividade, saída ou relacionamento entre áreas.

A seleção dos processos consiste em identificar os processos críticos da organização. Por processos críticos entende-se "processos que mais influenciam no conjunto das diretrizes estratégicas, e seu redesenho tem como objetivo torná-los competitivos perante os concorrentes" (ALBUQUERQUE; ROCHA, 2006, p.71). Após a seleção, devem-se estabelecer metas para melhoria dos processos que estarão relacionadas às saídas e refletirão no desempenho que o processo deverá passar a ter.

Estabelecidas todas essas etapas da Fase 1 - Análise do Contexto -, é necessária a composição da equipe, denominada por Albuquerque e Rocha (2006, p.73) de "Grupo Ideal”, que irá atuar no redesenho dos processos e deverá ser composta por "um representante de cada uma das áreas da organização que mais se envolve com o processo, aquelas que realizam a maior parte das atividades do processo ou algumas das atividades mais significativas" (ALBUQUERQUE; ROCHA, 2006, p.74).

Seguindo o modelo de Albuquerque e Rocha (2006), a Fase 2 - Análise do Processo Atual (As Is) - corresponde ao diagnóstico e ao levantamento da situação atual do processo, composta pelas etapas: mapa do processo; análise do desempenho do processo; identificação, priorização e classificação das rupturas; e tem por objetivo publicizar os retrabalhos, dificuldades e perdas originados dos processos críticos da organização.

Segundo Albuquerque e Rocha (2006), é aconselhável iniciar a Análise do Processo Atual (As Is) pela elaboração do mapa de contexto do processo, que pode ser com foco na organização ou em um processo específico. Ambos apresentarão as áreas da organização envolvidas e os relacionamentos mantidos entre si e com clientes externos. Porém, quando o 
foco está no processo, o mapa será mais detalhado, facilitando o desenho do fluxo de atividades e possibilitando uma visão macro do processo por todos da organização.

Conforme Albuquerque e Rocha (2006), em função de sua complexidade e, principalmente, por causa do gerenciamento funcional (vertical) das organizações, os processos interfuncionais não são conhecidos, entendidos, gerenciados e melhorados. Portanto, o mapa interfuncional do processo surge como um instrumento que possibilita que o processo atual seja conhecido por todos os envolvidos no processo, inclusive pela alta administração, facilitando seu entendimento e análise. Para a construção desse mapa, Albuquerque e Rocha (2006) enumeram a sequência a ser seguida:

Identificação do processo a ser mapeado;

Definição do início e fim do processo;

Identificação das funções que fazem parte de todo o processo;

Desenho da grade, onde cada função terá uma raia;

Identificação dos subprocessos e suas saídas;

Descrição de cada atividade do processo em uma caixa específica;

As saídas de cada atividade devem ser devidamente identificadas, pois correspondem à entrada para a atividade seguinte.

Após o mapeamento do processo atual, tem-se a etapa de levantamento do desempenho do processo atual que visa o conhecimento do processo em relação às metas de melhoria estabelecidas e as rupturas. Albuquerque e Rocha (2006, p.90) afirmam que "nem sempre é fácil levantar os dados do desempenho do processo atual, uma vez que a organização ainda não é gerida por processo e os indicadores são funcionais".

$\mathrm{Na}$ análise do contexto, as rupturas foram identificadas e metas de melhorias estabelecidas. Sendo assim, a priorização é feita pela análise de frequência e gravidade. Sendo entendida por gravidade, "o efeito que a ruptura provoca em termos de prejuízo financeiro, estresse organizacional, segurança do trabalho e/ou imagem da organização ou do produto no mercado" (ALBUQUERQUE; ROCHA, 2006, p. 92).

De acordo com Albuquerque e Rocha (2006), após a identificação e priorização, passa-se para a classificação das rupturas. As que podem ser resolvidas apenas pelo projeto de um novo processo na etapa de redesenho são as de processo. As rupturas de nível organizacional são causadas por normas internas, por falta de conhecimento dos níveis de competência etc. Relacionadas à falta de capacitação, perfil do cargo e sistemas de recompensa, estão classificadas as rupturas de pessoas. 
Albuquerque e Rocha (2006) recomendam que, antes de passar para a próxima fase de redesenho do processo, a análise do processo atual (As Is) deve ser apresentada para as áreas envolvidas com o intuito de ratificar ou retificar as rupturas e colher sugestões de melhoria. Além disso, deve ser validada pelos gestores da unidade/organização. Tendo em vista a complexidade de cada processo, não existe um prazo pré-determinado para realização da análise.

A Fase 3 - criação de novo processo - tem por finalidade corrigir as rupturas do processo atual e garantir o atendimento das metas de desempenho anteriormente definidas, por meio do redesenho do processo. Para isso, Albuquerque e Rocha (2006) projetaram uma sequência de passos que inclui: estabelecimento dos parâmetros, desenho do mapa interfuncional e elaboração dos procedimentos do novo processo; sumário das inovações propostas; e estabelecimento do sistema de medições do novo processo.

Os parâmetros do novo processo estão relacionados às características que o processo deve ter para que atinja as metas de melhoria almejadas e correção das rupturas. Conforme Albuquerque e Rocha (2006, p.98), “devem ser criados parâmetros para as saídas finais, para as entradas vindas de fornecedores e para as etapas do processo". A identificação dos subprocessos que compõem o processo inteiro facilita para o estabelecimento dos parâmetros, podendo ou não ser idênticos aos do processo atual.

Segundo Albuquerque e Rocha (2006, p.99), o desenho do mapa interfuncional do novo processo "tem o mesmo formato e convenções usados para o mapeamento do processo atual", devendo atender aos parâmetros do projeto e corrigir todas as rupturas, caso contrário, o fluxo deverá ser revisto. As rupturas classificadas como organizacionais ou de pessoas nem sempre são totalmente eliminadas e, para isso, "será necessária uma inovação (mudança de algum comportamento organizacional, do processo ou relacionado às pessoas, como: uma política, um procedimento, treinamento em alguma capacitação, alteração na estrutura organizacional etc.” (ALBUQUERQUE; ROCHA, 2006, p. 101).

Com o objetivo de facilitar o planejamento de implantação do novo processo, é necessária a sumarização de cada inovação, contendo: descrição resumida, resultados esperados, custos previstos, riscos, rupturas resolvidas e interdependência de outras inovações. Para Albuquerque e Rocha (2006), além disso, o estabelecimento do procedimento para cada atividade do mapa interfuncional do processo traz transparência aos executores, garantindo a uniformidade na execução.

Finalizando a Fase 3, encontra-se o estabelecimento do sistema de medições do novo processo que assegura o alinhamento entre estratégia, processos e pessoas e tem por objetivo 
“desenvolver indicadores de desempenho para o processo recém projetado (...) e será usado para o gerenciamento do processo, permitindo monitorar seu desempenho. É a ferramenta básica para o aperfeiçoamento contínuo" (ALBUQUERQUE; ROCHA, 2006, p.105).

Albuquerque e Rocha (2006) estabelecem três medições para o processo: medidas das saídas finais do processo que estão relacionadas aos outputs significativos de fim do processo; medidas intermediárias que descrevem os outputs de desempenho dos subprocessos; e medidas das atividades que medem o desempenho de uma atividade.

Além de estabelecer as medições, Albuquerque e Rocha (2006), sugerem uma sequência a ser seguida: 1. selecionar as saídas que serão medidas - saídas finais do processo e do subprocesso; 2. identificar os requisitos das saídas - o requisito pode ser: custo, prazo, volume e qualidade, variando conforme o foco de relevância da organização; 3. determinar como o requisito será medido - estabelecimento de uma fórmula para medir a saída em relação a cada requisito; 4. estabelecer o padrão que irá definir o resultado que o processo deverá produzir sempre que for medido; 5. definir o sistema de rastreabilidade - forma de como o desempenho dos processos em relação às saídas finais e intermediárias serão rastreadas.

Segundo Albuquerque e Rocha (2006, p.122),

o que se pretende com o redesenho do trabalho é construir o sincronismo organizacional, alinhando o trabalho aos processos e à estratégia e assegurando a integração dos indicadores de desempenho estratégicos, dos processos e dos postos de trabalho, além de eliminar as deficiências de desempenho das pessoas.

Nessa fase de redesenho do trabalho, são levadas em conta as rupturas causadas pelas deficiências de desempenho, que podem ser de capacitação - o indivíduo não sabe o que fazer, como fazer ou quando fazer; ou do ambiente - quando o fraco desempenho resulta de fatores externos ao indivíduo. Para Albuquerque e Rocha (2006) essa fase é direcionada aos elementos que influenciam no desempenho das pessoas, tais como: equipamentos disponíveis, a capacitação dos servidores ou a falta dessa, informações necessárias para tomada de decisão, resultados esperados etc.

Dessa forma, instrumentos foram criados por Albuquerque e Rocha (2006) para o redesenho do trabalho no nível das pessoas: padrão técnico do trabalho, sistema de feedback e programa de capacitação. Por meio do padrão técnico - que define missão do cargo, resultados do trabalho, requisitos, medida, padrão, recursos, conhecimento e habilidades - é possível fazer com que as pessoas conheçam os resultados do que devem gerar e saibam como serão mensurados, de modo que estejam capacitadas e tenham condições adequadas para exercer seu trabalho. 
Para que o feedback possa gerar resultados e promover as correções ou melhorias no trabalho desenvolvido,

precisa ser construído a partir do sistema de medições integradas. Esse sistema (...) é constituído dos indicadores estratégicos, dos processos e das pessoas (...). Os indicadores dos processos estão definidos na matriz de medição do processo e os indicadores das pessoas, no padrão técnico de trabalho" (ALBUQUERQUE; ROCHA, 2006, p. 137).

Outras medidas, citadas por Albuquerque e Rocha (2006), devem ser levadas em consideração para atingir um bom feedback: criação de um sistema de rastreamento do desempenho desejado; definição dos responsáveis pelo recebimento das informações; e sua periodicidade. Finalizando a fase de redesenho do trabalho, encontra-se a elaboração de programas de capacitação das pessoas envolvidas diretamente com processos nas organizações, tendo como foco o conhecimento e habilidade necessários, estipulados no padrão técnico do trabalho.

A quinta e última fase - gestão da transição - é o momento em que as mudanças projetadas se tornam reais e provocam impacto nas pessoas e áreas organizacionais. Albuquerque e Rocha (2006, p. 144) afirmam que:

\begin{abstract}
durante a transição, é ampliada a participação dos funcionários da organização, o que propicia o conhecimento dos novos processos, a disseminação da cultura organizacional voltada para o gerenciamento como um sistema integrado processador de produtos e serviços, e o efetivo comprometimento com a mudança.
\end{abstract}

Para Albuquerque e Rocha (2006, p. 144), “o desenvolvimento e a execução de um plano de renovação da cultura organizacional é condição essencial para o sucesso do novo modelo de gerenciamento por processos em oposição ao tradicional gerenciamento funcional".

Segundo os autores, completadas todas as fases e metas do modelo, bem como tomadas algumas providências - alocação de recursos financeiros; desativação gradativa do processo anterior; definição da lotação de recursos humanos, tendo como base o volume de transações dentro dos processos; e estabelecimento de uma estrutura de gerenciamento contínuo dos processos -, pode-se considerar que o sincronismo organizacional está implantado.

Apesar de Albuquerque e Rocha (2006) apresentarem um modelo de implantação da gestão por processos nas organizações, não está claro se há ou não uma unidade ou departamento responsável exclusivamente por processos. Porém, segundo Baldam, Valle e Rozenfeld (2014, p. 209), “a necessidade de um escritório de processos se faz presente 
quando o volume de processos a gerenciar ultrapassa a capacidade de ser conduzido como atividade paralela por outros processos". Sendo assim, para maior aprofundamento sobre a implantação da gestão por processos, torna-se relevante seu estudo.

\subsection{ESCRITÓRIO DE PROCESSOS}

Para Paim et al. (2009, p.239),

Devido à crescente complexidade e abrangência dos processos nas organizações e à frequência com que a modelagem, a melhoria, a implantação, a integração e a coordenação de processos têm acontecido - muitas vezes de forma isolada - é cada vez maior a necessidade de empresas e instituições se estruturarem para gerenciar seus processos.

Pensando na estruturação da organização por meio da gestão por processos, surgiu a necessidade de criação de uma unidade responsável por promover a governança dos processos, disseminar culturalmente esse modelo de gestão, promover a modelagem dos processos e sua gestão no dia-a-dia. Dessa forma, segundo Jesus e Macieira (2014), surge a denominação 'escritório de processos'. Baldam, Valle e Rozenfeld (2014, p. 209-210) afirmam que "o escritório de processos institucionaliza a gestão dos processos tornando a ação como parte do cotidiano e da cultura organizacional", bem como que se "deve cuidar do bom andamento e a coordenação dos processos de negócios na organização”.

Para Tregear, Jesus e Macieira (2010, p.33) o escritório de processos é:

o ponto focal para coordenação de melhorias de processos e atividades de gestão de processos. Ele apoia toda a organização com padrões de conformidade, metodologias, modelos, educação, auxílio a projetos e coaching. O escritório garante práticas consistentes para alcançar os objetivos da gestão por processos em tempo adequado e com boa relação custo-benefício.

Paim et al. (2009, p.245), ao tratar das formas de atuação do escritório de processos, afirmam que

a visão sistémica do escritório sobre o processo permite uma análise mais eficaz,
gerando (e coordenando) sugestões de melhoria que beneficiem um dado processo
como um todo. Seu objetivo vai além das tarefas sistemáticas de modelagem,
análise, proposta de melhorias e redesenho dos processos, propondo-se a constituir a
instância organizacional responsável por inserir e gerir a prática de gestão de ou por
processos no escopo de atuação e na cultura da organização.

De acordo com Paim et al. (2009), o escritório de processos pode possuir os seguintes posicionamentos dentro da estrutura organizacional - normativo-colaborativo; coordenador; e normativo e coordenador -, dependendo da sua forma de atuação. O escritório 
normativo colaborativo é responsável por normatizar a gestão por processos, desde a governança até a implantação. O coordenador é responsável pela gestão por processos no diaa-dia, atuando de forma a complementar o trabalho desenvolvido pelo escritório normativo. $\mathrm{O}$ terceiro e último posicionamento é resultado da junção dos escritórios normativo e coordenador, acumulando as funções de ambos.

Conforme descrição da Quadro 3, elaborada por Paim et al. (2009), dependendo da forma de atuação do escritório de processo, poderão ser definidos os macro-objetivos a serem alcançados e que justificam a implantação dessa unidade, e as atividades específicas e consistentes que, além de dar suporte ao alcance dos objetivos, estão relacionadas ao escopo da organização, cujos processos estão sendo gerenciados.

Quadro 3: Relação dos macro-objetivos e atividades do escritório de processos

\begin{tabular}{|c|c|c|c|}
\hline \multicolumn{3}{|c|}{ Macro-objetivos do Escritório de Processos } & Atividades do Escritório de Processos \\
\hline \multirow{25}{*}{ 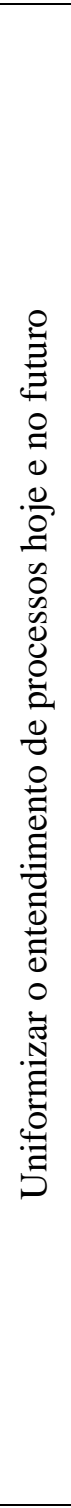 } & \multirow{9}{*}{\multicolumn{2}{|c|}{ Promover a gestão de processos }} & Promover a governança dos processos \\
\hline & & & $\begin{array}{l}\text { Articular estratégia, processos e abordagem } \\
\text { de mudança }\end{array}$ \\
\hline & & & Selecionar processos \\
\hline & & & Selecionar sistemas de gestão de processos \\
\hline & & & Selecionar técnicas de gestão de processos \\
\hline & & & $\begin{array}{l}\text { Gerenciar o orçamento do escritório de } \\
\text { processos }\end{array}$ \\
\hline & & & $\begin{array}{l}\text { Gerenciar o portfólio de projetos de gestão de } \\
\text { processos }\end{array}$ \\
\hline & & & Gerenciar a qualidade da gestão de processos \\
\hline & & & $\begin{array}{l}\text { Gerenciar os processos do escritório de } \\
\text { processos }\end{array}$ \\
\hline & \multirow{10}{*}{ 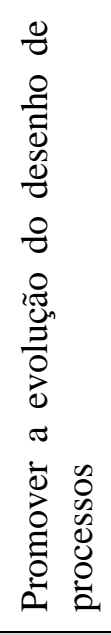 } & Modelar e representar processos & Gerenciar o levantamento de processos \\
\hline & & $\begin{array}{l}\text { Promover a melhoria do } \\
\text { desempenho dos processos }\end{array}$ & Gerenciar a melhoria de processos \\
\hline & & $\begin{array}{lll}\text { Integrar mecanismos } & \text { de } \\
\text { coordenação organizacional } & \end{array}$ & $\begin{array}{l}\text { Definir indicadores de desempenho para os } \\
\text { processos }\end{array}$ \\
\hline & & & Definir sistemas para os processos \\
\hline & & & Definir competências para os processos \\
\hline & & & Definir responsáveis para os processos \\
\hline & & & Definir procedimentos para os processos \\
\hline & & & Definir riscos para os processos \\
\hline & & Implantar processos & $\begin{array}{l}\text { Gerenciar a implantação de mudanças nos } \\
\text { processos }\end{array}$ \\
\hline & & $\begin{array}{llll}\begin{array}{l}\text { Capacitar os } \\
\text { processos }\end{array} & \text { gestores } & \text { de } \\
\end{array}$ & Preparar equipes de gestão de processos \\
\hline & \multirow{5}{*}{\multicolumn{2}{|c|}{ Promover a gestão no dia-a-dia }} & Acompanhar a execução dos processos \\
\hline & & & Controlar a execução dos processos \\
\hline & & & Registrar o desempenho dos processos \\
\hline & & & Controlar desvios de impacto \\
\hline & & & Avaliar o desempenho dos processos \\
\hline & \multicolumn{2}{|c|}{ Oferecer suporte ao escritório } & Manter sistemas do escritório de processos \\
\hline
\end{tabular}




\begin{tabular}{|l|l|}
\hline \multirow{2}{*}{$\begin{array}{l}\text { Preparar e manter equipe do escritório de } \\
\text { processos } \\
\text { Registrar o aprendizado sobre processos } \\
\text { Manter o plano de comunicação do escritório } \\
\text { de processos }\end{array}$} \\
\hline
\end{tabular}

Fonte: Elaborado por Paim et al. (2009, p.248).

O escritório de processos pode ser inserido nas mais diversas formas de estruturas organizacionais e sua atuação dependerá da forma com que a organização visualiza seus processos. A Figura3, elaborada por Paim et al. (2009, p.253), apresenta uma proposta de alocação desse escritório em uma estrutura organizacional orientada por processos. Nessa estrutura, os processos são priorizados, cabendo ao escritório acumular as funções normativa e coordenadora, responsabilizando-se pela gestão dos processos no dia-a-dia. Aos departamentos ou unidades cabe apenas a divisão dessa responsabilidade.

Figura 3: Proposta de alocação do escritório de processos em uma gestão por processos

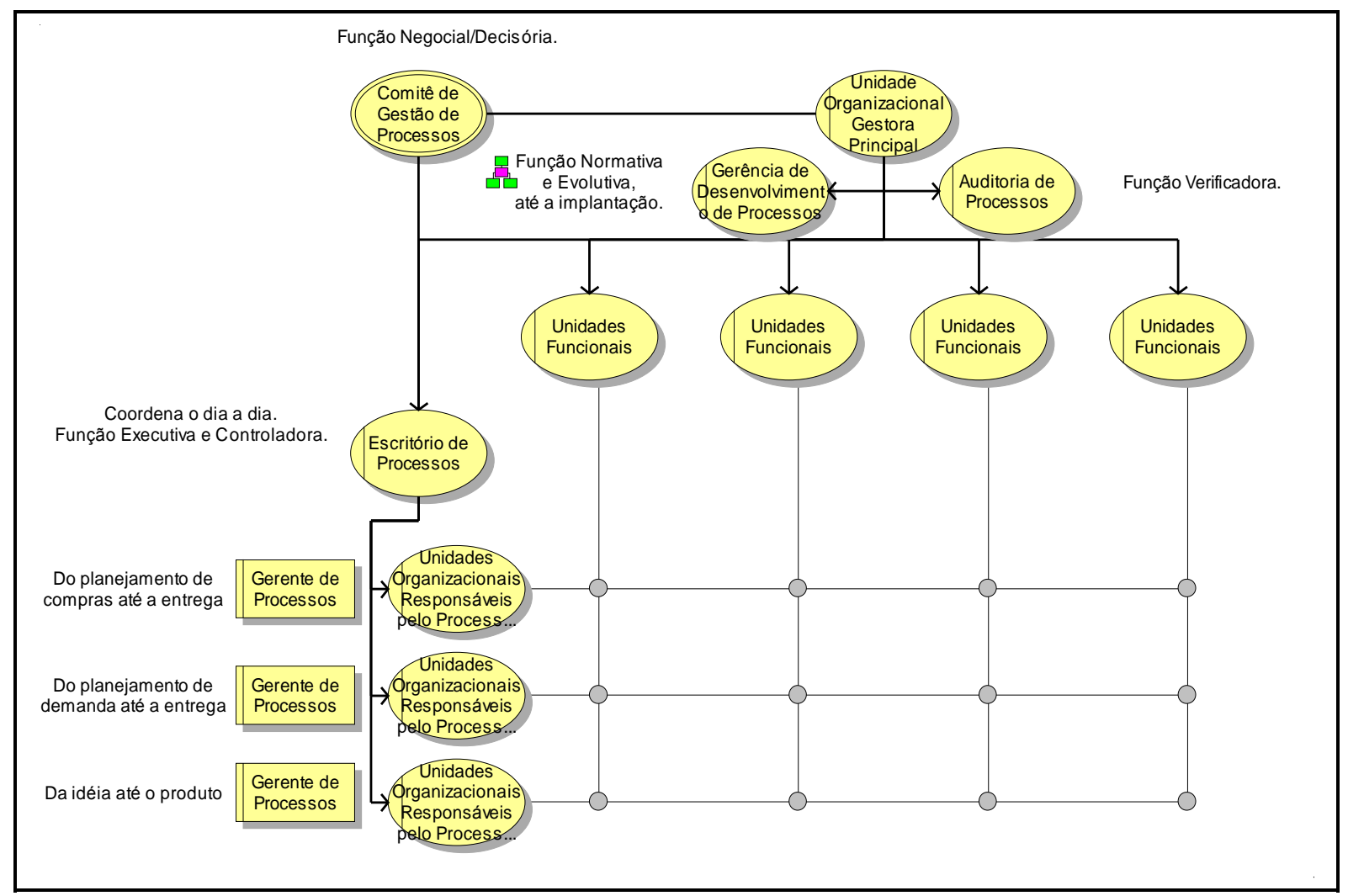

Fonte: Elaborado por Paim et al. (2009, p.253).

Para Tregear, Jesus e Macieira (2010, p.44), “um escritório de processos trabalhará melhor se for uma unidade centralizada fisicamente, ao invés de ser dividida por toda a organização". Já para Paim et al. (2009, p.245), “o escritório deve estar apto a priorizar 
processos, não necessariamente trabalhando com todos da organização. Ele pode focar nos seus processos-chave ou definir, através de um método, sobre quais processos deve atuar”.

Tregear, Jesus e Macieira (2010) apresentam três modelos de operação de um escritório de processos. Ao operar no modo direcionador, o escritório possui autoridade suficiente para interferir nas atividades dos outros departamentos, garantindo as práticas de gerenciamento dos processos. Quando se limita apenas a responder às demandas das demais unidades e disseminar a cultura de processos, diz-se que está operando como servidor. E o escritório que possui algum poder de coerção, mas deixa a critério de cada unidade se quer ou não participar do gerenciamento de processos, opera como facilitador.Tanto o Guia BPM CBOK (2013) como também Tregear, Jesus e Macieira (2010) estabelecem uma relação entre a maturidade da gestão por processos na organização e o escritório de processos. Quando a análise, melhoria e gerenciamento de processos é recente, diz-se que a maturidade é baixa e as organizações tendem a ser dependentes da equipe do escritório para conduzir projetos de qualquer natureza. Conforme a maturidade da organização em relação à gestão por processos vai aumentando, os demais departamentos ficam responsáveis pela gestão do dia-a-dia de seus processos, podendo o escritório focar na manutenção de padrões e disseminação de conhecimentos.

Segundo Baldam, Valle e Rozenfeld (2014, p.210),

São atribuições típicas de um escritório de processos: gerenciar as metodologias de
gestão de processos; gerenciamento do ciclo de vida de processos; treinamento e
desenvolvimento de pessoal nas melhores práticas e difusão de aprendizagem; apoio
aos gestores dos processos no acompanhamento e avaliação do processo; e realizar
interlocução entre gestores de processos e a alta administração.

A adoção do escritório de processos pelas organizações apresenta vantagens, como: alinhamento entre os processos de negócios e o planejamento estratégico da organização; disseminação dos produtos dos processos; atribuição das responsabilidades e autoridades pelos processos essenciais e críticos; otimização de recursos para o estudo de melhoria de processos; evitar retrabalho em relação às iniciativas de processo etc. (BALDAM; VALLE; ROZENFELD, 2014).

Segundo Tregear, Jesus e Macieira (2010) e Baldam, Valle e Rozenfeld (2014), os recursos, a equipe e a infraestrutura necessárias ao escritório de processos dependerão do tamanho da organização e da quantidade de processos a ser gerenciada. O quadro de servidores do escritório de processos geralmente é permanente, devendo esses membros ser especializados em abordagens, conceitos, métodos, técnicas e ferramentas de gerenciamento de processos para atuarem como consultores internos em iniciativas de transformação. Devem 
ter familiaridade e prover consistência na disponibilização de normas, regras e políticas que regem o gerenciamento de processos e os processos de mudança na organização (GUIA BPM CBOK, 2013).

Conforme o Guia BPM CBOK (2013), a equipe de escritório de processos será composta por servidores que serão responsáveis por desempenhar mais de um papel. Os mais comuns são: dono de processos; gerente de processos; analista de processos; designer de processos; e arquiteto de processos.

Baldam, Valle e Rozenfeld (2014) descrevem alguns itens desejáveis que devem fazer parte da estrutura física do escritório para seu bom funcionamento, como: quadros largos com pinceis; mesa de reunião grande; local adequado para projeção; computadores com monitores de tamanho grande e boa resolução; sala com paredes amplas etc. E compondo a estrutura de software, os itens são: ferramenta de modelagem; editor de textos; planilha eletrônica; software para apresentações; e ambiente de publicação. Tanto a parte de estrutura física, como de software, irá influenciar diretamente no desempenho dos serviços de melhoria de processo e gestão do dia-a-dia, desenvolvidos pela equipe do escritório.

A governança de processos de uma organização é responsabilidade do escritório de processos. Santos (2014) define governança de processos como:

\footnotetext{
o conjunto de melhores práticas que garante: a tomada de decisões certas pelos gestores responsáveis; e direcionamento da gestão de processos nas organizações de forma a viabilizá-la como um elemento organizacional capaz de contribuir para um efetivo aumento da performance dos processos e, consequentemente, da performance da organização.
}

Segundo Santos (2014), não há um modelo de escritório de processos pronto a ser implementado nas organizações. Essas devem, a partir do entendimento das necessidades, desenvolver o modelo que atenda aos requisitos de negócio e as expectativas das partes interessadas. Tendo em vista a importância da implantação do escritório de processos para a estruturação das organizações baseada no modelo da gestão por processos, torna-se essencial a descrição de como está sendo conduzida pelas instituições públicas a adoção desse modelo.

\subsection{GESTÃO POR PROCESSOS NAS INSTITUIÇÕES PÚBLICAS}

As instituições públicas brasileiras têm procurado "adotar os novos modelos de gestão aplicados em empresas privadas no intuito de melhorar a qualidade de seus serviços" (CUNHA, 2012, p. 7). Por trabalharem com uma atividade não-fabril, torna-se ainda mais relevante o trabalho por processos, segundo Gonçalves (2000, p. 14), "uma vez que a 
sequência de atividades nem sempre é visível, nem pelo cliente, nem por quem realiza essas atividades". Além disso, segundo Fiel Filho (2010), por se tratarem de organizações que trabalham com poucos recursos e muitas demandas sociais, exige-se maior capacidade de gestão. Assim, faz-se necessária uma administração de processos, para que estes possam gerar produtos/serviços que atendam às expectativas e necessidades dos cidadãos.

As instituições públicas apresentam atributos diferentes das privadas e que devem ser considerados na implantação da gestão por processos, segundo Baldam, Valle e Rozenfeld (2014). Tendo em vista seu caráter público, as ações devem ser transparentes e os procedimentos de execução dos processos de livre acesso aos clientes. Possuem como objetivo principal a prestação se serviços que atendam às necessidades da população e que não visam lucro, tendo características peculiares de continuidade, regularidade, uniformidade, generalidade, obrigatoriedade e regulação. Ou seja, os serviços prestados devem ter caráter ininterrupto, igualitário e obedecer regras pré-estabelecidas.

Porém, conforme Fiel Filho (2010), quando se pretende uma mudança para uma gestão por processos nas instituições públicas, além das dificuldades igualmente encontradas nas empresas privadas, outros fatores devem ser levados em consideração, dentre os quais a burocratização e o distanciamento do cidadão.

De acordo com Vaz (2008), a adoção da gestão por processos pelas instituições públicas é mais propicia aos insucessos, tendo em vista as dificuldades legais, escassez de recursos, incertezas políticas e descontinuidade administrativa. Entre os fatores mais relevantes para essa adoção, estão: apoio e participação dos gestores e da alta administração; disponibilidade de tempo pelas equipes internas; transparência de dados e informações relacionados ao desempenho dos processos atuais; priorização do redesenho de processos considerados críticos pela organização; comunicação entre as areas ao longo de todo o processo; e condução clara da metodologia pela equipe responsável.

Para Biazzi e Muscat (2007), esse cenário de lentidão administrativa e serviços que não satisfazem à população decorre de uma gestão fundamentada em estruturas excessivamente rígidas e hierarquizadas. De forma geral, os processos de trabalho nas instituições públicas brasileiras caracterizam-se pelo apego exagerado às normas, sem que haja um questionamento das rotinas de trabalho. Além disso, conforme Junquilho (2004), verifica-se no setor público brasileiro uma forte resistência a controles formalizados e avaliações formais de desempenhos. Por isso, Biazzi, Muscat e Biazzi (2011) afirmam que os projetos de melhoria devem levar em conta as características específicas do setor público - 
dentre as quais se destacam hierarquias rígidas, ênfase em mudanças de curto prazo e constantes mudanças de direção política.

Segundo Cruz (2012, p.121),

o tipo de administração que a maioria das organizações ainda pratica está baseado no imediatismo das situações do dia-a-dia, que são resolvidas de forma ad hoc. Isso ocorre devido a um conjunto de disfunções cujas origens remontam a hábitos antigos que muitos profissionais insistem em manter. Esse tipo de administração só pode dar certo se a estrutura hierárquica for mantida, uma vez que prevalece a lei do mais forte, o que manda fazer, sobre o mais fraco, o que obedece e faz.

Para Biazzi (2007), a estrutura organizacional apresentada pelas instituições públicas brasileiras contribui efetivamente para a visão funcional, burocracia, aversão a controles formalizados e comportamento centralizador. Usualmente, o modelo utilizado é funcional, que, segundo Paim et al. (2009, p.125), apresenta "características de silos, com baixa capacidade de coordenação e, principalmente, com processos desconhecidos".

A alteração na estrutura da instituição, de uma visão funcional para uma visão orientada por processos, conforme Gonçalves (2000, p.15), “implica definir a responsabilidade pelo andamento do processo, minimizar as transferências, maximizar o agrupamento de atividades e diminuir o gasto de energia”. Para Baldam, Valle e Rozenfeld (2014, p.15),

a visão por processos relaciona e expõe as atividades que fazem a organização funcionar, não se limitando à estrutura fixa e departamental dos organogramas, valorizando também a cooperação, o trabalho em equipe e a responsabilidade de cada colaborador que participa e é responsável pelo processo.

Paim et al. (2009, p.296) afirmam que implantar o modelo de gestão por processos nas instituições públicas não é apenas "enfatizar os processos em oposição à hierarquia e colocar ênfase sobre os resultados e clientes", implicando em alterar a estrutura organizacional e os elementos integrantes. Nesse modelo, os servidores não trabalham mais nas areas funcionais, e sim, no processo, enxergando o negócio como processos interdependentes, com a finalidade de promover melhorias e ter o reconhecimento de todos que fazem parte da organização. Há integração externa e interna entre as atividades que compõem os processos e a informação não tem o filtro da hierarquia, seguindo diretamente para o interessado.

Para Vaz (2008, p. 3), a gestão por processos é um "excelente instrumento para reverter a tendência à constituição de burocracias autocentradas no setor público", na medida em que os processos precisam estar direcionados para atender às demandas dos clientes, internos ou externos. Entretanto, o próprio Vaz (2008) ressalva que, no setor público, há 
grande risco de insucesso das iniciativas de redesenho de processo devido às características do setor - empecilhos legais, falta de recursos, incertezas políticas e descontinuidade administrativa.

Biazzi, Muscat e Biazzi (2011) afirmam que para o alcance do êxito na gestão por processos, em especial nas instituições públicas brasileiras, é importante preparar a organização para a intervenção, com uma compreensão correta dos objetivos a serem alcançados e o comprometimento de todos.

Santos, Santana e Alves (2012) realizaram uma pesquisa que objetivou analisar a relação existente entre fatores críticos de sucesso encontrados na literatura e fatores enfrentados nas iniciativas de implantação da gestão por processos pelas instituições públicas. Esse estudo foi realizado em quatro organizações que estão passando pelo processo de implantação e identificou que alguns desses fatores podem ser facilitadores ou barreiras nessa implantação. Como barreiras foram apontados: burocracia e cultura do setor público; histórico de falhas em projetos realizados por consultorias e que não foram concluídos, ocasionando sentimento de frustração e desconfiança nas pessoas; legislação obrigatória obsoleta que impede as melhorias; falta de integração entre as unidades organizacionais; obrigatoriedade em seguir as legislações; rotatividade de pessoal, pois o gasto despendido em treinamento e o conhecimento adquiridos são perdidos; e a descontinuidade dos projetos por causa da troca de governo.

Os fatores críticos identificados por Santos, Santana e Alves (2012) nas organizações públicas pesquisadas foram: apoio da alta administração; competência das equipes de processos; composição da equipe por servidores do quadro; comunicação da equipe com os demais membros da organização; conscientização dos benefícios proporcionados pela gestão por processos aos clientes internos; e capacitação dos envolvidos diretamente com os processos.

Paim et al. (2009, p. 296) afirmam que algumas instituições não adotam uma estrutura organizacional por processos, mas uma orientação por processos que é "um modelo que prioriza a gestão organizacional a partir dos processos ou que é centrado na ideia de que os processos devem apoiar a coordenação do trabalho. Isso não demanda, necessariamente, uma mudança na estrutura organizacional". Ou seja, possuem uma estrutura funcional, mas gerenciam seus processos transversalmente.

Para melhor visualização, a Figura 4, elaborada por Paim et al. (2009, p. 134), apresenta uma trajetória de mudança da estrutura funcional tradicional até uma estrutura orientada por processos. Na primeira, os processos não estão representados formalmente, 
havendo apenas integração de departamentos ou unidades organizacionais. A segunda imagem apresenta uma estrutura matricial fraca, onde os processos transversais são gerenciados, mas a organização continua funcional. A terceira caracteriza-se por uma estrutura matricial forte, porém com priorização dos processos. A quarta representa uma estrutura por processos pura, tendo apenas uma linha de autoridade centrada na coordenação ao longo do fluxo de trabalho e os processos transversais são o principal eixo em torno do qual a organização constrói seu projeto. Para Paim et al. (2009), as duas últimas formas são utilizadas particularmente na Gestão por Processos.

Figura 4: Alternativas de estruturas organizacionais

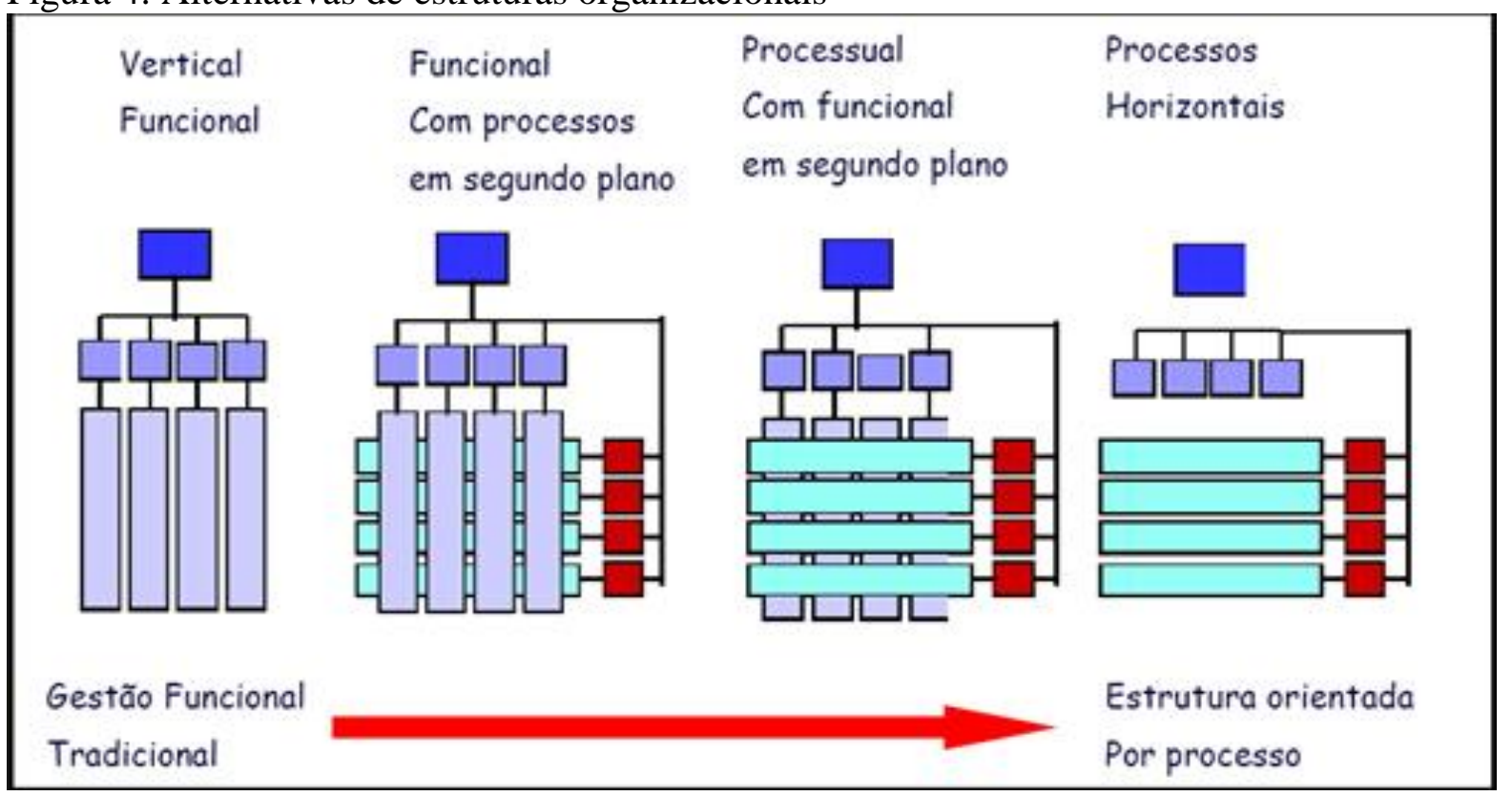

Fonte: Elaborado por Paim et al. (2009).

Para Jesus e Macieira (2014, p.58),

a gestão por meio de processos pressupõe nos capacitarmos para evoluir gradativamente em busca de um sistema de gestão mais colaborativo, com ênfase na responsabilidade transversal, organização do trabalho para atendimento das necessidades dos clientes e partes interessadas. (...) Enquanto uma (gestão de processos) foca em gerenciar o ciclo de vida de um determinado processo, buscando sua evolução constante, a outra (gestão por processos) pressupõe alterações corporativas maiores em toda a forma de pensar e gerir um negócio.

Baldam, Valle e Rozenfeld (2014) afirmam que o gerenciamento por processos é um habilitador de melhorias de processos na gestão pública e apontam algumas oportunidades de atuação desse modelo nas instituições públicas, como: implantação do e-GOV - programas de Governo Eletrônico que tem como princípio a utilização das modernas tecnologias de informação e comunicação; necessidade de simplificar o atendimento ao cidadão; 
obrigatoriedade de garantir ao cidadão o acesso à informação; e aumento de produtividade imposta pela sociedade. Destaca-se o apoio do Governo Federal na utilização de gerenciamento por processos, como uma das formas de apoiar o e-GOV.

Baldam, Valle e Rozenfeld (2014, p.14) citam como exemplo o "Guia de Gestão de Processos no Governo, que na primeira parte consiste em um documento de orientação metodológica de suporte à gestão de processos e, na segunda parte, converge para a contratação de serviços de modelagem de processos".

\subsection{GESTÃO POR PROCESSOS NAS INSTITUIÇÕES PÚBLICAS DE ENSINO SUPERIOR (IPES)}

Atualmente, a sociedade brasileira vem buscando serviços melhores e que atendam aos interesses da população de forma transparente. Inseridas nesse contexto encontram-se as Instituições Públicas de Ensino Superior (IPES) que têm por objetivo desenvolver e disseminar o conhecimento. Essas Instituições são mantidas pelo Governo e são classificadas pelo Ministério da Educação (MEC) como: universidades, centros universitários e faculdades. Existem ainda outras denominações, como institutos superiores, escolas superiores e faculdades integradas. As instituições públicas são criadas e mantidas pelo poder público nas três esferas - federal, estadual e municipal (BRASIL, 2006).

Para a sobrevivência da educação e prestação de um serviço de qualidade é necessário um relacionamento adequado entre sociedade e instituições de ensino superior. Esse relacionamento permitirá que a organização se adapte às mudanças e se ajuste às necessidades sociais. Marcovith (1998, p.22) afirma que "são as transformações mundiais em todas as áreas de atividade humana, que devem mover as estratégias acadêmicas”.

Conforme Pessoa (2000), as IPES possuem um enfoque sistêmico, pois se constituem em um conjunto de processos que são alimentados por entradas (informações, conhecimento, recursos) que resultam em saídas (produção científica, formação profissional) em um constante ciclo de realimentação, sofrendo influências do ambiente externo.

De acordo com Vieira e Vieira (2004), as universidades federais brasileiras primam por estruturas organizacionais extremamente burocráticas tanto no campo administrativo como no campo acadêmico, tornando as três dimensões da atividade acadêmica universitária ensino, pesquisa e extensão - reféns da burocracia, submetida a normas e dependências muitas vezes desnecessárias produzidas pelas estruturas piramidais de apoio. 
Para Silva Jr. (2000), tudo parece indicar que, ao longo dos séculos, as universidades foram estruturadas para mudar lentamente, como forma de perenizar suas atividades. Diferente do cenário mundial, a universidade mostra-se estática e se acomoda, limitando- se à repetição. Corroborando com esse pensamento, Vieira e Vieira (2004) afirmam que o grande impasse no processo de mudança nas universidades públicas está na resistência explícita e velada à qualquer cogitação de transformar as realidades arcaicas que dominam as instituições públicas de ensino superior. Apontando três razões para esse comportamento: o medo à mudança, os interesses pessoais e a proteção corporativa.

Sendo assim, as IPES passam por um período que exige mudanças capazes de tornálas mais ágeis e flexíveis para cumprir sua função social com eficiência. Para tanto, conforme Pessoa (2000), é necessário que estejam ajustadas às novas formas de gestão e práticas administrativas, que atendam à necessidade de informações e conhecimento que é criada pelas transformações políticas, econômicas, sociais e tecnológicas.

Para que haja esse ajuste às novas formas de gestão e práticas administrativas é importante o comprometimento de todos os envolvidos na organização das IPES. Assim, as pessoas do nível estratégico, tático e operacional participam do planejamento, das propostas e da execução de mudanças para atendimento das demandas atuais.

Para Vieira e Vieira (2004), a mobilização das comunidades universitárias às mudanças estruturais, organizacionais, acadêmicas e, principalmente, de comportamento passando de uma cultura burocrática à outra pós-burocrática - é o grande passo no caminho da reestruturação. Universidades estruturadas em faculdades, centros, institutos, decanatos, departamentos, escolas, colégios, comissões, coordenações, núcleos e outras formas funcionais tendem naturalmente a se constituir em organismos burocráticos de grande densidade e dispersão de poder.

O alinhamento das organizações, tanto privadas como públicas, com a metodologia da gestão por processos é vagaroso e complicado. Segundo Müller (2003), a quebra de paradigmas há muito tempo enraizados na cultura executiva necessária para o enfoque na gestão por processos pode ser encarada como um dos principais desafios das organizações modernas.

Para Meyer Jr, Pascucci e Mangolin (2012), como geradora de conhecimentos e saberes, as instituições de educação superior brasileiras, em particular as universidades, têm enfrentado constantes desafios de gestão e de busca de formas mais eficientes e eficazes de atuação provocados por mudanças no ambiente. Entre os motivadores da mudança estão aspectos relacionados à política educacional, as demandas do setor produtivo, as flutuações na 
demanda por cursos e as renovadas necessidades e expectativas dos discentes. Segundo Bolzan (2006), no ambiente interno das universidades, a busca pela qualidade é um dos caminhos trilhados pela gestão para melhorar os processos acadêmicos e administrativos como contribuição à solução dos graves problemas que envolvem a gestão universitária.

Dessa forma, afirmam Biazzi, Muscat e Biazzi (2011), a implementação da gestão por processos nas IPES deve ser utilizada com o objetivo de planejar e executar melhor as atividades pela definição adequada de responsabilidades, uso dos recursos de modo mais eficiente, realização de prevenção e solução de problemas, eliminação de atividades redundantes, aumentando a produtividade, com agregação de valor à prestação de serviços ao cidadão.

\subsubsection{Casos de sucesso}

Algumas instituições públicas têm utilizado a metodologia da gestão por processos para uma maior eficiência e eficácia dos seus serviços prestados. Como é o caso da Secretaria de Estado de Planejamento e Gestão de Minas Gerais que utilizou o Guia para Melhoria de Processos do Governo de Minas Gerais (BRASIL, 2011) na aplicação de um estudo a respeito dos processos de emissão de carteira de identidade e de emissão de atestado de antecedentes criminais. Esse estudo chegou à conclusão que

\footnotetext{
as iniciativas no sentido de reestruturar os processos de trabalho viabilizaram a melhoria do clima organizacional e, em certa medida, o maior envolvimento dos funcionários na execução das ações de melhoria. Portanto, foi possível perceber a importância de repensar a forma como a administração pública funciona e buscar aprimorar-se (FERREIRA et al., 2014).
}

Outro estudo interessante que objetivou a melhoria dos processos críticos teve aplicação na Coordenação do Curso de Graduação da Universidade Federal da Paraíba. Os processos críticos priorizados foram matrícula e montagem de blocagem. Após o mapeamento dos processos e as propostas apresentadas do estudo para agilizar o andamento dos processos críticos, Salgado et al. (2013, p. 166) chegaram à conclusão de que "a gestão por processos pode ser aplicada em instituições públicas, trazendo benefícios para a organização”.

Atualmente, a iniciativa que mais se destaca, e que está sendo utilizada como modelo de redesenho e gerenciamento de processos nas Instituições Federais de Ensino Superior, é a implantação do Escritório de Processos (EP) da Universidade Federal do Rio Grande do Sul (UFRGS). Segundo Brodbeck et al. (2013), trata-se de uma unidade relacional, normativa e 
coordenadora, que prescreve métodos e ferramentas que orientam a gestão por processos na organização, atuando nos níveis estratégico, tático e operacional.

Dentre os propósitos alcançados do EP, conforme afirmam Brodbeck et al. (2013), está a criação de uma metodologia de implementação da visão por processos na Instituição, a qual contempla o Gerenciamento de Processos de Negócios (BPM), e envolve o relacionamento dos processos com estratégias, mapas de contexto, macrofluxos dos processos finalísticos e de apoio.

A capacitação dos servidores foi um passo importante para implementação da metodologia do EP e disseminação da cultura de processos na Instituição. Segundo Brodbeck et al. (2013, p.5), “como resultado dos cursos, o EP recebe os diagramas as is específicos de cada unidade, mapeados no padrão estabelecido pelo EP, os quais são publicados na área de Processos do Portal do Servidor, validados pelos usuários e com a lista de oportunidades de melhorias".

O primeiro processo crítico diagramado foi o de Compras, tendo em vista que apresentou problemas em vários relatórios da auditoria em relação ao tempo de execução, à eficácia e à utilização dos recursos e, principalmente, pela falta de padronização. De modo correlacionado, padrões, métodos e ferramentas foram sendo desenvolvidos para orientar a gestão dos processos da Instituição.

A apresentação do EP da UFRGS é essencial para demonstrar a importância de sua implementação como impulsionador na proposição de melhorias na gestão e disseminador da visão e cultura de processos, além de proporcionar capacitação contínua dos servidores. A metodologia e os resultados positivos apresentados pela Instituição têm demonstrado melhorias na eficiência e eficácia dos processos que fizeram com que a Universidade de Brasília (UnB) se interessasse pelo tema, buscando estabelecer parceria com a UFRGS com o intuito de implantar e disseminar a gestão por processos. 


\section{METODOLOGIA}

Derivado do grego méthodos - caminho para chegar a um objetivo - e logos conhecimento, metodologia, segundo Demo (1989), é entendida como o conhecimento crítico dos caminhos de processos científicos, indagando e questionando acerca dos limites e possibilidades. Nesta pesquisa, a metodologia é importante para que se possa apontar aspectos que contribuam com a implantação da gestão por processos adotada pela Diretoria de Processos Organizacionais (DPR), atribuindo-lhe caráter científico. Sendo assim, torna-se necessário descrever o tipo de pesquisa utilizada, sua abordagem, as características da organização na qual foi aplicada, os instrumentos e procedimentos de coleta de dados, e de que modo se procedeu a análise dos dados obtidos.

\subsection{TIPO DE PESQUISA}

A abordagem utilizada foi a pesquisa qualitativa por se preocupar com aspectos da realidade que não podem ser quantificados, centrando-se na compreensão e explicação da dinâmica das relações sociais. De acordo com Sampieri, Collado e Lucio (2006, p. 15), essa pesquisa "dá profundidade aos dados, a dispersão, a riqueza interpretativa, a contextualização do ambiente, os detalhes e a experiência única. Também oferece um ponto de vista recente, natural e holístico dos fenômenos, assim como flexibilidade".

Segundo Creswell (2007), a pesquisa qualitativa possui características próprias, tais como: ocorre em um cenário natural; utiliza métodos múltiplos para coleta de dados; participação ativa dos participantes; dados coletados envolvem dados em texto; as questões de pesquisa e métodos de coleta podem mudar durante a pesquisa, caso seja necessário; e é fundamentalmente interpretativa. Dessa forma, trata-se de um estudo exploratório que, segundo Gil (2008, p.27), "é desenvolvido para proporcionar uma visão geral, acerca de determinado fato. Realizado especialmente quando o tema escolhido é pouco explorado e torna-se difícil sobre ele formular hipóteses precisas e operacionalizáveis".

Por ser uma pesquisa exploratória, foi utilizado o estudo de caso seguindo os princípios de Yin (2005), que o descreve como uma investigação empírica que examina um fenômeno contemporâneo dentro do contexto da vida real, especialmente quando os limites entre esse e o contexto não estão claramente definidos.

Desta forma, o estudo de caso, segundo Fonseca (2012, p.33), 
Pode ser caracterizado como um estudo de uma entidade bem definida como um programa, uma instituição, um sistema educativo, ou uma unidade social. Visa conhecer em profundidade o como e o porquê de uma determinada situação que se supõe ser única em muitos aspectos, procurando o que há nela de mais essencial e característico. O pesquisador não pretende intervir sobre o objeto a ser estudado, mas revelá-lo tal como ele o percebe.

Esta pesquisa foi desenvolvida junto à Universidade de Brasília, utilizando-se como instrumentos de coleta de dados: pesquisa bibliográfica; pesquisa documental; e entrevistas semi-estruturadas. Para análise dos dados, foi empregada a técnica de análise de conteúdo.

Este estudo teve como limitação o fato de que, na realização do contexto temporal, as pessoas responsáveis pela Diretoria de Processos Organizacionais, desde sua criação até outubro de 2013, não foram localizadas, de modo que os resultados apresentados ficaram restritos à análise documental e opinião de apenas um participante que estagiava na Diretoria nessa época, o que poderia agregar novas informações.

Outra limitação, refere-se ao fato de que durante a realização da pesquisa houve transição da Direção da DPR, tendo em vista a aposentadoria da diretora. Desse modo, a continuação desse estudo pode contribuir no sentido de identificar quais são as mudanças na metodologia e o impacto dessas na gestão por processos da Universidade, vislumbrando se houve ou não melhoria dos processos.

\subsection{CARACTERÍSTICAS DA ORGANIZAÇÃO}

Para a realização da pesquisa empírica, a Instituição Pública de Ensino Superior selecionada foi a Universidade de Brasília, tendo em vista que vem promovendo ações para a implantação do modelo de gestão por processos e criação do escritório de processos.

Conforme o Relatório de Gestão 2014/UnB, a Universidade foi criada e é mantida pela Fundação Universidade de Brasília (Lei n. 3.998, de 15 de dezembro de 1961), sendo regida por Estatuto (1994) e, subsidiariamente, pelo Regimento Geral e por normas complementares.

Segundo o Estatuto da UnB (1994), a instituição tem por finalidade prestar serviço de qualidade nas áreas de ensino, pesquisa e extensão, integrados na formação de cidadãos qualificados para o exercício profissional e empenhados na busca de soluções democráticas para os problemas nacionais. Possui autonomia didático-científica, administrativa e de gestão financeira e patrimonial, em conformidade com a Constituição Federal. Sua forma de gestão segue princípios da gestão democrática, descentralização e racionalidade organizacional. 
Em relação à estrutura e a suas competências institucionais, cabe sintetizar que a UnB está estruturada por: Conselhos Superiores, que são os órgãos normativos, deliberativos e consultivos; Reitoria, que é o órgão executivo superior; Unidades Acadêmicas, que são os institutos e as faculdades; Órgãos Complementares e Centros. Ligados à Reitoria estão o Gabinete do Reitor, os Decanatos, a Procuradoria Jurídica, a Auditoria, as assessorias, o serviço de apoio aos colegiados superiores e a Prefeitura do Campus. O Gabinete do Reitor e a Prefeitura do Campus são considerados órgãos auxiliares. A Procuradoria Jurídica e a Auditoria são consideradas órgãos de apoio e auxílio na tomada de decisões.

A figura 5, Relatório de Gestão - Exercício 2014 (2015, p.24), apresenta o organograma funcional da Instituição com a representação das áreas/subunidades consideradas estratégicas para o desenvolvimento de Ensino, Pesquisa e Extensão. 
Figura 5: Organograma Funcional da UnB

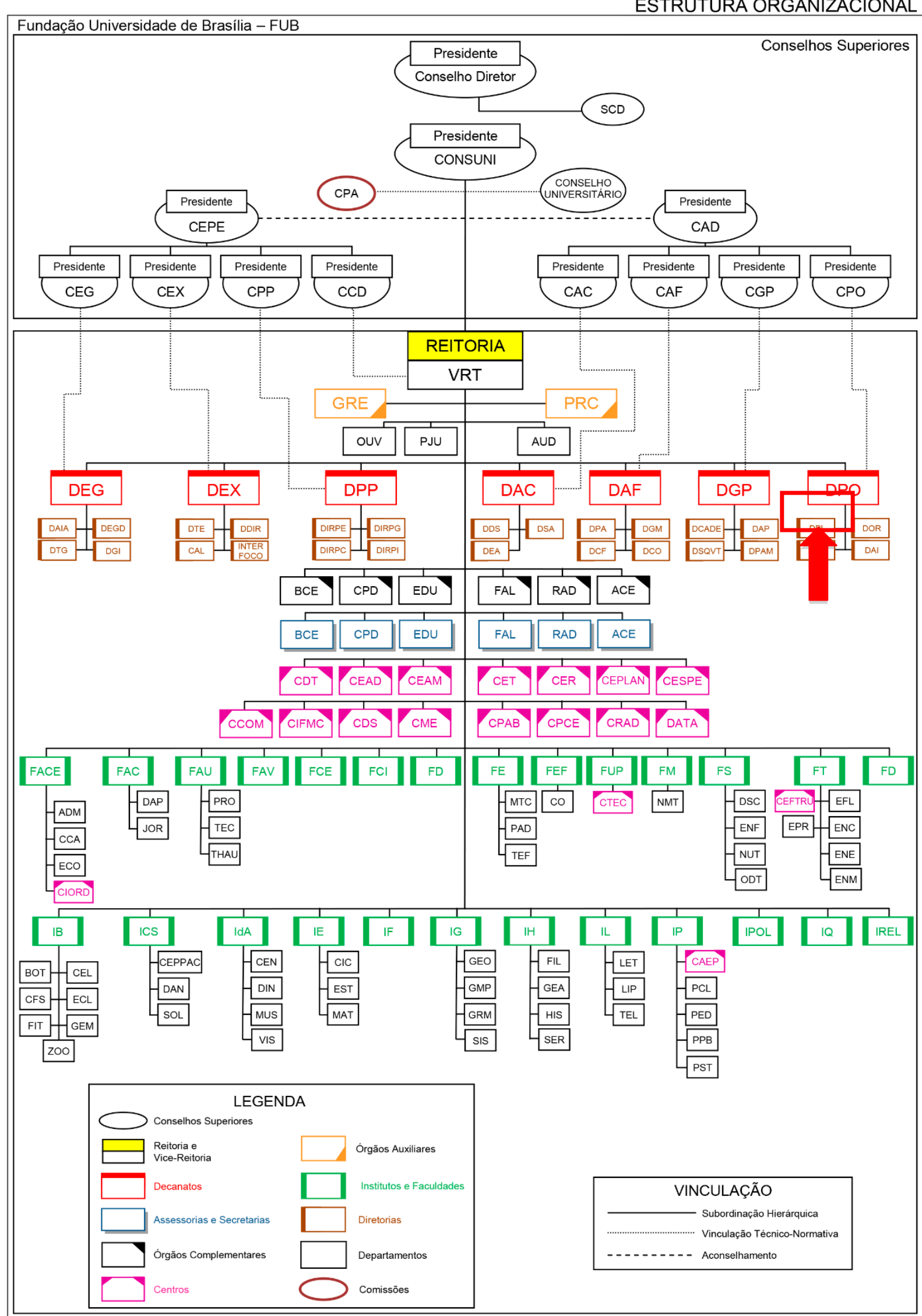

Decanato de Planejamento e Orçamento - DPO

Fonte: Relatório de Gestão - Exercício 2014 (2015, p.24). 
Após selecionar a organização de pesquisa, os trabalhos passaram a ser desenvolvidos juntamente à Diretoria de Processos Organizacionais (DPR), uma das quatro diretorias que fazem parte da estrutura organizacional do Decanato de Planejamento e Orçamento (DPO), aprovada pelo Ato da Reitoria $\mathrm{n}^{\mathrm{o}}$ 385/2011, de 18 de março de 2011. A Figura 6 apresenta o organograma do DPO, tendo em destaque a DPR. Sendo composta por duas coordenadorias: Coordenadoria de Apoio ao Gerenciamento de Processos e Coordenadoria de Apoio à Estruturação Organizacional.

Figura 6: Organograma do DPO

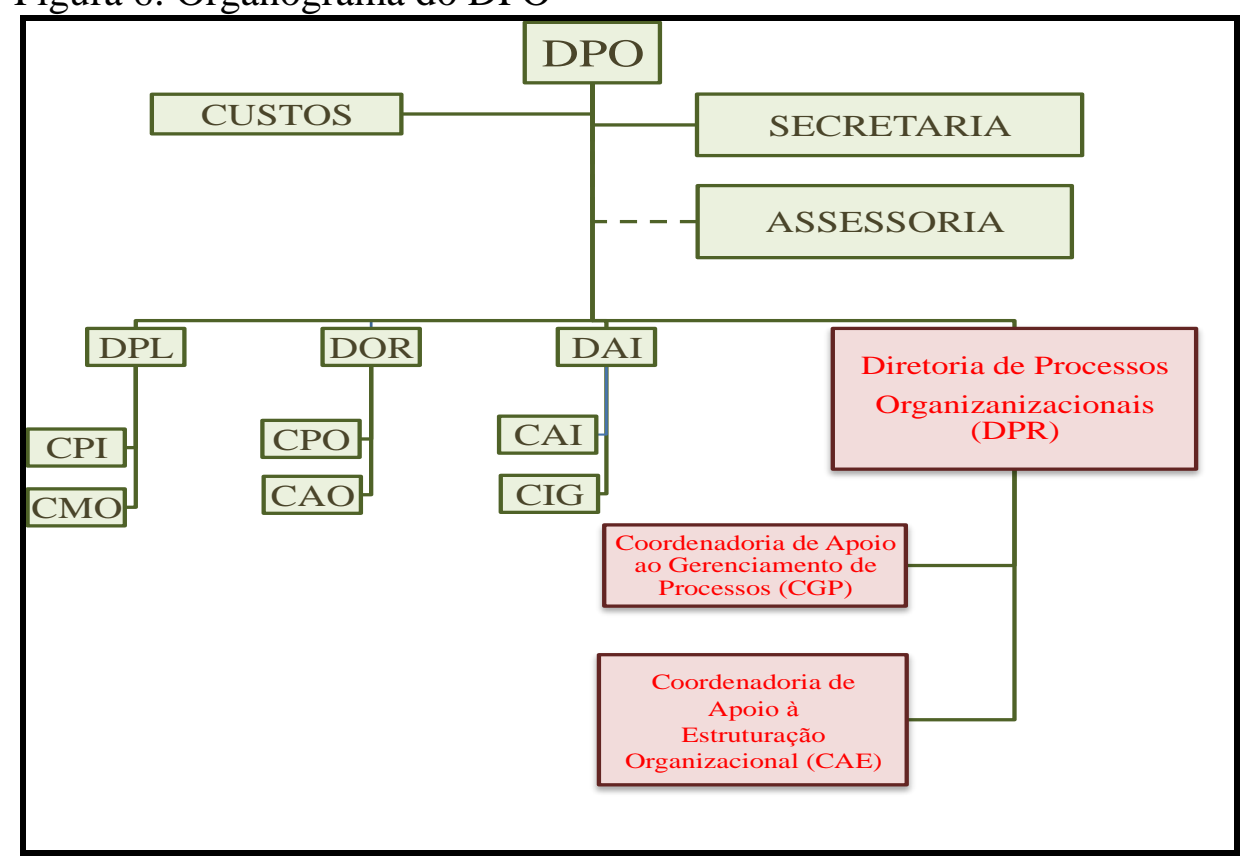

Dentre as competências da DPR, as que se enquadram ao objeto da pesquisa são: realizar estudos e análises para o desenvolvimento e aperfeiçoamento da gestão por processos e racionalização organizacional; definir e manter padrões, metodologias e ferramentas para o gerenciamento de processos e promover sua adoção na organização; guardar o conhecimento sobre os processos da organização e disseminar e capacitar nas práticas recomendadas para gerenciamento de processos.

\subsection{PARTICIPANTES DA PESQUISA}

Conforme Duarte (2012), o processo de seleção dos participantes em estudos qualitativos pode ser de dois tipos: por conveniência, ocorre quando as fontes são escolhidas por proximidade ou disponibilidade; e intencional, quando o pesquisador utiliza o juízo 
particular, como o entendimento relacionado ao tema ou representatividade subjetiva. Nesta pesquisa o processo de seleção foi intencional, ou seja, os atores são profissionais envolvidos diretamente no processo de implantação da gestão por processos na Universidade e contribuíram para o entendimento do problema e da questão de pesquisa.

Foram conduzidas 10 entrevistas individuais, sendo quatro com servidores técnicoadministrativos da equipe da DPR responsável pelo apoio e gerenciamento de processos na Instituição; quatro com servidores técnico-administrativos da DAIA que estão trabalhando com mapeamento de processos; uma com docente ocupante de cargo da alta administração; e uma com docente que presta consultaria sobre o tema para a Universidade. A Tabela 1 apresenta os dados biográficos dos participantes com relação a cargo e função; tempo na função e cargo; escolaridade; e faixa etária.

Tabela 1: Dados biográficos dos participantes

\begin{tabular}{|c|c|c|c|c|c|}
\hline $\begin{array}{l}\text { Nível do } \\
\text { Cargo }\end{array}$ & Função & $\begin{array}{l}\text { Tempo na } \\
\text { Função }\end{array}$ & Escolaridade & $\begin{array}{c}\text { Tempo no } \\
\text { Cargo }\end{array}$ & $\begin{array}{l}\text { Faixa } \\
\text { Etária }\end{array}$ \\
\hline Médio & $\begin{array}{c}\text { Secretário } \\
\text { de Comissão }\end{array}$ & Entre 5 e 10 & Superior Incompleto & Entre 20 e 30 & 51 a 60 \\
\hline Médio & Coordenador & Até 1 & Especialização & Entre 1 e 3 & 20 a 30 \\
\hline Médio & Coordenador & Entre 1 e 3 & Superior Completo & Entre 20 e 30 & 41 a 50 \\
\hline Superior & Diretor & Entre 1 e 3 & Especialização & Mais de 30 & 51 a 60 \\
\hline Superior & - & - & Especialização & Até 1 & 20 a 30 \\
\hline Superior & - & - & Mestrado & Entre 1 e 3 & 20 a 30 \\
\hline Superior & Coordenador & Até 1 & Especialização & Entre 3 e 5 & 20 a 30 \\
\hline Superior & Coordenador & Entre 1 e 3 & Especialização & Entre 5 e 10 & 20 a 30 \\
\hline Superior & Decano & Entre 1 e 3 & Doutorado & Entre 20 e 30 & 51 a 60 \\
\hline Superior & Consultor & Entre 5 e 10 & Doutorado & Mais de 30 & 51 a 60 \\
\hline
\end{tabular}

Cabe ressaltar que, dentre os 10 participantes, $70 \%$ ocupam cargo de nível superior; $80 \%$ possuem função de chefia, sendo que, dentre esses, $75 \%$ estão na função há menos de três anos. Em relação à escolaridade, $80 \%$ possuem formação acadêmica acima de 
especialização. De acordo com o tempo no cargo, 50\% está há menos de 10 anos no cargo e $50 \%$ há mais de 20 anos. Assim como em relação à faixa etária, 50\% está entre 20 a 30 anos e $50 \%$ entre 41 a 60 anos.

Dessa forma, em relação aos dados demográficos, infere-se que a equipe de participantes é composta por profissionais com formação acadêmica especializada, ocupantes de função gerencial na UnB, sendo metade com experiência de mais de 20 anos de Instituição. Essa divisão, de tempo no cargo e faixa etária, apresentou-se como favorável para a pesquisa, pois assim o pesquisador obteve visões diferenciadas, dos mais aos menos experientes, em relação à um mesmo propósito: adoção de um novo modelo de gestão organizacional.

\subsection{INSTRUMENTO DE COLETA DE DADOS}

Para a coleta de dados foram utilizadas as seguintes técnicas: pesquisa bibliográfica (MARCONI; LAKATOS, 2003); pesquisa documental (FRANCO, 2013); e entrevistas semiestruturadas (YIN, 2015).

Para Stumpf (2012, p.54), a pesquisa bibliográfica é:

um conjunto de procedimentos para identificar, selecionar, localizar e obter documentos de interesse para a realização de trabalhos acadêmicos e de pesquisa, bem como técnicas de leitura e transcrição de dados que permitem recuperá-los quando necessário.

A pesquisa bibliográfica iniciou-se pela escolha do objeto de estudo: implantação da gestão por processos na UnB; elaboração de um esquema provisório, no qual o tema central foi dividido em subtemas; e definição das palavras-chave: processos; gestão por processos; e instituições públicas. A seguir, iniciou-se pesquisas em livros, artigos científicos, periódicos, estudos de caso, dissertações e teses. Nos últimos 10 meses, foram consultadas as seguintes bases de dados: Capes, Scielo, ProQuest e BDTD.

A pesquisa documental envolveu a investigação em documentos internos da organização estudada que são: Estatuto; Regimento; Atos; Regulamentos etc.; e documentos externos, que são aqueles de outras entidades governamentais e oficiais que auxiliaram no desenvolvimento da pesquisa. Segundo Gil (2008), sua utilização possibilita: o conhecimento do passado; a investigação dos processos de mudança social e cultural; e a obtenção de dados com menor custo e sem constrangimento dos sujeitos envolvidos. Por essa pesquisa se tratar de estudo de caso, ressalta Yin $(2015$, p.111) que "o uso mais importante dos documentos é para corroborar a informação de outras fontes". 
Para Yin (2015, p.114) "uma das fontes mais importantes de informação para o estudo de caso é a entrevista". O tipo de entrevista utilizado na pesquisa foi a semi-estruturada que, conforme Sampieri, Collado e Lucio (2006, p. 381), "baseia-se em um guia de assuntos ou questões e o pesquisador tem a liberdade de introduzir mais questões para a precisão de conceitos ou obter maior informação sobre os temas desejados”.

\subsection{PROCEDIMENTOS DE COLETA DE DADOS}

A coleta de dados é fundamental para uma pesquisa qualitativa pois permite uma análise profunda e completa de eventos, situações, experiências, crenças e comportamentos. Segundo Yin (2015), para a realização da coleta de dados em um estudo de caso, deve-se observar quatro princípios: utilizar duas ou mais fontes de evidência; criação de um banco de dados; manter o encadeamento de evidências; e ter cuidado no uso de dados de fontes eletrônicas.

O procedimento de coleta de dados iniciou-se pela separação e triagem dos documentos oficiais da Universidade de Brasília pertinentes ao tema da pesquisa. Foram utilizados: Plano de Desenvolvimento Institucional 2014-2017 (PDI); Ato da Reitoria; Memorando da DPR; os Relatórios de Gestão de 2011 a 2014; e Boletins Informativos da DPR. Após a triagem, elaborou-se uma planilha no Excel, separada por documento, contendo as principais informações de cada um, com data de publicação, finalidade, origem e abrangência.

Sampieri, Collado e Lucio (2006, p. 382) afirmam que:

a entrevista deve ser um diálogo e deixar que flua o ponto de vista, único e profundo, do entrevistado. $\mathrm{O}$ tom deve ser espontâneo, indutivo, cuidadoso e com certo ar de 'curiosidade' por parte do entrevistador. Não devemos incomodar o entrevistado. Também é recomendado descartar questões muito diretas, e não questionar de maneira tendenciosa ou induzindo respostas.

Para Yin (2015), existem três tipos possíveis de entrevista de estudo de caso: prolongadas; curtas; e de levantamento. No caso da prolongada, a duração é de duas ou mais horas, em um único ou vários encontros, passando o entrevistado de participante para 'informante'. As curtas têm duração de até uma hora e são focadas no tema em questão. $\mathrm{O}$ outro tipo é a de levantamento que utiliza um questionário estruturado, podendo produzir dados quantitativos.

Nesta pesquisa, seguindo a tipologia estabelecida por Yin (2015), utilizou-se a entrevista curta de estudo de caso, tendo em vista os procedimentos adotados, como: 
utilização de um protocolo, neste caso, o roteiro; tempo de duração das entrevistas foi inferior a uma hora; e as questões foram cuidadosamente elaboradas para que os entrevistados corroborassem com as informações necessárias para o estudo, evitando-se perguntas condutoras.

Além de utilizar a tipologia de Yin (2015), a entrevista utilizada nesta pesquisa foi a semi-estruturada, pois as questões foram formuladas de forma que os entrevistados discorressem e verbalizassem sobre suas reflexões em relação ao tema apresentado. Segundo Manzini (1990, p.154), nessa entrevista “a resposta não está condicionada a uma padronização de alternativas formuladas pelo pesquisador como ocorre na entrevista com dinâmica rígida”.

Em seguida, elaborou-se o roteiro da entrevista (Apêndice A), com questões-guia baseadas no problema de pesquisa, o qual, segundo Manzini (2004), serviu para a coleta de informações básicas e como meio para o pesquisador se organizar para o processo de interação com o participante da pesquisa. Foram levados em consideração, na formulação das perguntas do roteiro, alguns cuidados quanto à linguagem e à forma e sequência das perguntas.

Dessa forma, o roteiro utilizado apresentou questões com vocabulário de fácil entendimento, sem utilização de jargões técnicos, possibilitando que sua leitura pelo entrevistador e entendimento pelo entrevistado ocorressem sem dificuldades. As perguntas foram curtas e ordenadas, de modo que favoreceu o rápido engajamento do respondente na entrevista, bem como a manutenção do seu interesse. A seguir, são descritas as perguntas direcionadas aos participantes e seus objetivos, que fizeram parte do roteiro prévio.

1. Fale sobre a origem da gestão por processos na UnB.

Objetivo: identificar o início da gestão por processos na UnB.

2. Qual é o propósito estratégico para a UnB na adoção da gestão por processos?

Objetivo: identificar a razão de ser (objetivo estratégico) das estratégias adotadas pela $\mathrm{DPR} / \mathrm{UnB}$.

3. Fale sobre a metodologia adotada para implementação da gestão por processos na UnB.

Objetivo: qual a metodologia aplicada para GP na UnB.

4. Quais são ou foram os processos críticos identificados pela DPR?

Objetivo: identificar a ocorrência de processo crítico, qual setor e procedimentos adotados pela DPR.

5. Quais são as vantagens na implantação da gestão por processos na UnB? 
Objetivo: identificar os fatores que facilitaram a implantação da gestão por processos.

6. Quais são as dificuldades identificadas na implantação da gestão por processos?

Objetivo: identificar fatores dificultadores na implantação da gestão por processos.

A partir da primeira entrevista, os demais participantes foram selecionados e, após um contato prévio, foi possível o devido agendamento, respeitando os dias e horários determinados pelos entrevistados. Para cada entrevista realizada, o pesquisador, ao se identificar, solicitou permissão para gravação e posterior transcrição das informações obtidas, e apresentou que a implantação por gestão por processos na UnB é o foco da investigação. Não houve objeção por nenhum dos entrevistados, de modo que as entrevistas transcorreram normalmente. Durante esse processo, foram anotados os dados importantes identificados.

\subsection{ANÁLISE DOS DADOS}

Após a coleta dos dados, foi necessária a análise e a interpretação dos dados obtidos, e optou-se pelo emprego da técnica de análise de conteúdo. De acordo com Franco (2003), o uso dessa técnica "passou a ser utilizada para produzir inferências acerca de dados verbais e/ou simbólicos, mas, obtidos a partir de perguntas e observações de interesse de um determinado pesquisador".

Os dados extraídos de documento e entrevistas realizadas constituem o corpus que foi submetido à análise de conteúdo. Essa análise, segundo Bardin (2006), compreendeu três etapas básicas: pré-análise; exploração do material; e tratamento dos dados e interpretação. $\mathrm{Na}$ primeira etapa, o material analisado foi organizado de maneira operacional, sistematizando-se as ideias iniciais. A princípio, foi feita a leitura 'flutuante' dos documentos selecionados e transcrição das entrevistas.

Ainda na pré-análise, as principais regras, para a determinação do corpus, estabelecidas por Franco (2003), foram utilizadas: exaustividade, na qual esse foi representado por todos os documentos referentes à implantação da gestão por processos; representatividade, que permitiu que a análise fosse efetuada em profundidade, mesmo sem amostragem, pois o conteúdo se mostrou relevante, significativo e consistente para o estudo da gestão por processos; homogeneidade, na qual a escolha do corpus obedeceu a critérios pertinentes aos objetivos da pesquisa, sendo que, no caso das entrevistas realizadas, as 
questões se referiram ao tema escolhido, utilizando-se de técnicas e situações semelhantes para os entrevistados e respeitando a similaridade entre os participantes.

Após a organização e leitura meticulosa do corpus, passou-se para a etapa de exploração do material que, segundo Bardin (2006), corresponde a descrição analítica, em que esse foi submetido a um estudo aprofundado, possibilitando interpretações e inferências. Dessa forma, foi possível a identificação dos termos frequentemente encontrados e relacionados à implantação da gestão por processos e seus desdobramentos.

A partir disso, passou-se para a categorização que, na definição de Franco (2003, p.51), "é uma operação de classificação de elementos constitutivos de um conjunto, por diferenciação seguida de um reagrupamento baseado em analogias, a partir de critérios definidos".

Para Franco (2003, p.51) “a criação das categorias é o ponto crucial da análise de conteúdo". Neste caso, as categorias foram criadas a posteriori, ou seja, definidas e interpretadas cruzando as informações emitidas nas verbalizações dos entrevistados, os documentos selecionados e o arcabouço teórico desta pesquisa.

Respeitadas as características, determinadas por Franco (2003), de exclusão mútua; homogeneidade; objetividade; fidelidade; e produtividade, as categorias criadas nesta pesquisa não possuem o mesmo elemento em duas categorias, obedecendo a homogeneidade. Refletem as intenções do pesquisador, sendo que os procedimentos classificatórios foram objetivos, garantindo a fidelidade de resultados férteis em índice de inferências, dados e novas hipóteses.

Na terceira etapa de tratamento dos dados e interpretação, segundo Bardin (2006), ocorreu a condensação dos resultados obtidos, culminando nas interpretações inferências do pesquisador. Esse momento de intuição, análise reflexiva e crítica é apresentado no próximo capítulo. 


\section{ANÁLISE E DISCUSSÃO}

Como resultado desta pesquisa,foi possível a criação de quatro categorias: origem da gestão por processos; propósitos estratégicos para adoção da gestão por processos; vantagens na adoção da gestão por processos; e dificultadores para a implantação da gestão por processos. Ademais, foi possível a identificação da metodologia de implementação da gestão por processos e dos processos críticos. Esses resultados são apresentados separadamente após um contexto temporal sobre a gestão por processos na UnB.

\subsection{CONTEXTO HISTÓRICO}

A estrutura organizacional do Decanato de Planejamento e Orçamento (DPO) foi constituída pelo Ato da Reitoria n³58/2011, em 18/03/2011. Dentre as quatro diretorias que compõe essa estrutura, encontra-se a Diretoria de Processos Organizacionais (DPR), conforme Figura 6, apresentada no capítulo correspondente à metodologia. Em 10/09/2015, foi publicado o Ato da Reitoria $\mathrm{n}^{\mathrm{o}} 1014 / 2015$, revogando o ato anterior, e aprovando a atualização da estrutura organizacional do DPO. Em relação à DPR, não houve alteração, mas apenas a oficialização da subdivisão em duas coordenadorias: Apoio ao Gerenciamento de Processos (CGP); e Apoio à Estruturação Organizacional (CAE).

Desde a criação da DPR, com a constante preocupação na prestação de serviços de qualidade, a UnB passou a buscar um modelo de gestão por processos para a Instituição. A metodologia utilizada teve como referência o Programa Nacional de Gestão Pública e Desburocratização (GesPública), criado pelo Decreto 5.383, de 3 de março de 2005, juntamente com o Guia de Simplificação e o Guia de Gestão por Processos, reconhecendo nesse material aderência às melhores práticas previstas no BPM CBOK (Business Process Management CommomBodyofKnowledge)

O Guia "d" Simplificação Administrativa foi elaborado para auxiliar qualquer organização pública interessada em simplificar seus processos e normas, eliminando exigências de rotinas que geram fluxos desconexos na tramitação de documentos que não agregam valor ao serviço prestado pela organização e, por consequência, pelo Estado. O Guia de Gestão de Processos de Governo é composto de duas partes. A primeira consiste em um documento de orientação metodológica de suporte à Gestão por Processos; e a segunda foca na contratação de serviços de modelagem de processos. 
O Guia para o Gerenciamento de Processos de Negócio - Corpo Comum de Conhecimento (BPM CBOK)é um documento de propriedade da ABPMP - Associationof Business Process Management Professionals -e serve como referência básica para profissionais de BPM - Business Process Management -, identificando e fornecendo uma visão geral das áreas de conhecimento necessárias para essa prática, bem como todas as fases para a realização de um projeto de BPM ideal. Inclui papéis e estruturas organizacionais, bem como provisões para conduzir uma organização orientada por processos (ABPMP CBOK, 2013).

Desde a criação da DPR em 2011 até 2012, a técnica utilizada para o gerenciamento dos processos da Universidade era o Business Process Management (BPM), por ser de padrão aberto e de mercado independente do fornecedor, permitindo um envolvimento das pessoas e ser economicamente viável. Para o mapeamento dos processos, seguindo a técnica de BPM, utilizava-se o software BizAgiModeler. Essa ferramenta possibilita a criação de fluxogramas, mapas mentais e diagramas em geral. Permitindo aos usuários organizarem graficamente vários processos e as relações existentes em cada etapa. O software possui separadamente o módulo de modelagem, que é utilizado pela equipe da DPR, e o módulo servidor, que executa o processo.

Algumas iniciativas de mapeamento de processos foram iniciadas no Centro de Manutenção de Equipamentos (CME), no Decanato de Extensão e o processo de compras da Universidade. Não há informação divulgada se esses mapeamentos foram concluídos e validados. Como não havia acompanhamento, eram procedidos de maneira isolada, sem o devido conhecimento dos envolvidos do que vinham a ser processos, o porquê desse mapeamento e qual sua importância. Não havia uma perspectiva para que os trabalhos fossem efetivados, fazendo com que os servidores começassem esse trabalho de mapeamento e logo em seguida o abandonassem, o que ocorria porque não havia uma padronização em termos de artefatos, metodologia e padrões. Ademais, o número de colaboradores era insuficiente para construir indicadores dentro dos processos. A DPR não tinha preocupação em disseminar para a comunidade a visão por processos, promover eventos, palestras, ficando a gestão por processos apenas no âmbito da Diretoria.

A DPR estava, de maneira geral, buscando o conhecimento e a padronização das rotinas organizacionais, com foco voltado para os processos de apoio, tendo em vista que os processos finalísticos que envolvem o ensino, pesquisa e extensão dependiam da contratação de pessoas, contratação de serviços, e compra de bens, dificultando assim para que a Universidade conseguisse implantar um modelo de gestão por processos. Dessa forma, 
observa-se que não houve uma metodologia para a implementação da gestão por processos e nem padronização de procedimentos para o mapeamento dos processos, de modo que esses eram feitos de maneira isolada e sem o devido alinhamento com o planejamento estratégico. Não foram estabelecidas políticas de atuação e nem de integração dessa Diretoria com as demais unidades da UnB.

Em 2013, com o início do mandato da nova Reitoria e do novo gestor do Decanato de Planejamento e Orçamento (DPO), a gestão por processos na Universidade ganhou apoio e voltou ao foco. Uma nova diretora de processos organizacionais, que no ano de 2012 trabalhou na DPR como analista de processos, foi nomeada em outubro de 2013, iniciando-se, assim, estudos e pesquisas com o objetivo de propor um modelo de gestão por processos, com enfoque administrativo, que atendesse às necessidades da UnB. Inicialmente, utilizou-se uma metodologia simples para que, caso houvesse alguma demanda dos demais setores, a Diretoria pudesse dar um apoio inicial em relação aos processos.

Em abril de 2014, a Diretora de Processos Organizacionais encaminhou ao Reitor da UnB, um documento explicando a importância da gestão por processos e solicitando a institucionalização do seu enfoque administrativo. O documento também informava que os processos do Decanato de Planejamento e Orçamento (DPO) foram mapeados, que os processos do Arquivo Central (ACE) e que alguns processos executados pelo Decanato de Administração (DAF) estavam no início do mapeamento e a Diretoria havia recebido uma solicitação para mapeamento dos processos da Diretoria de Manutenção de Equipamentos (DIMEQ). Diante desse mapeamento e da Diretora ter trabalhado por muitos anos no Centro de Processamento de Dados, a Diretoria pôde visualizar a importância de uma gestão integrada entre processos e tecnologia da informação, no sentido de adequar os processos da Universidade às funcionalidades de um sistema integrado e, dessa forma, customizar o sistema por processos mais aderentes e não pelos que apresentam problemas.

Sendo assim, o memorando apontou a relevância da implantação da governança de Tecnologia da Informação (TI) e, reafirmou que, para tanto, a adoção da gestão por processos se fazia necessária, dando ênfase à importância da TI no conhecimento das necessidades da Instituição e do seu planejamento estratégico. Diante disso, o Reitor submeteu à sua ciência e à concordância com a institucionalização da gestão por processos na UnB.

Ainda em 2014, na busca pela metodologia de implementação da gestão por processos na Instituição e criação do escritório de processos, a DPR convidou a consultora Ângela Freitag Brodbeck, professora da Universidade Federal do Rio Grande do Sul (UFRGS), responsável pela implantação do Escritório de Processos dessa Universidade, para 
ministrar palestras com o objetivo de disseminar a gestão por processos. Em suas apresentações para a alta administração da Universidade, ressaltou a importância do alinhamento estratégico entre as áreas de tecnologia de informação e negócio, o apoio da alta administração e, principalmente, a institucionalização da gestão por processos como parte integrante do planejamento estratégico com seus indicadores de desempenho de processos alinhados.

Além disso, a consultora identificou quatro questões importantes para a criação do EP na UnB como: passos metodológicos de construção de padrões e modelos de negócios;passos metodológicos de construção de padrões para processos;disseminação da visão por processos - oficinas; e disseminação da metodologia de gestão por processos programas de capacitação dos envolvidos.

Os passos metodológicos de construção de padrões e modelos de negócios compreendem: diagramas de contexto do modelo de negócio e dos macroprocessos finalísticos e de apoio; a matriz de processos; e a determinação dos processos críticos a serem mapeados imediatamente. A realização dos dois primeiros passos pela DPR resultou no Contexto dos Macroprocessos Finalísticos, apresentado no Relatório de Gestão 2014 (Doc7/2015). Em relação aos processos críticos, foram identificados pela alta administração da UnB os processos organizacionais do Arquivo Central (ACE) e o processo de elaboração e execução do orçamento do Decanato de Administração e Finanças (DAF).

Nos passos metodológicos de construção de padrões para processos estavam: criação de instrumentos para levantamento de processos atuais (as is); dinâmica dos processos; homologação do processo atual (as is), criação de instrumentos para identificação de rupturas e melhorias, plano de implantação do novo processo, testes e ajuste da nova forma de trabalho ao novo processo. Desta questão, resultou-se a metodologia para mapeamento e modelagem de processos utilizada pela DPR e no mapeamento dos processos críticos acima descritos.

Para disseminação na UnB da gestão por processos, foram promovidos alguns eventos, como: Planejamento Estratégico da UnB, em 2014; e o BPM Day, em 2015. Ademais, os processos mapeados e modelados podem ser visualizados no site da Universidade. A DPR elaborou um plano de capacitação para os servidores com o intuito de disseminar a metodologia dessa gestão por meio de cursos mensais de 40 horas e anual de 150 horas, porém, tendo em vista a escassez de recursos, esse planejamento ainda não foi colocado em prática.

Com o início da presente pesquisa, foi evidenciado nas entrevistas realizadas em maio de 2015 que a contratação da consultoria se encontrava na PJU desde julho de 2014, e 
que por várias vezes retornou à DPR com pareceres diversos. Em um desses, questiona-se a implantação da gestão por processos, utilizando o BPM (Business Process Management), tendo em vista que o termo 'business' está relacionado a lucro e a UnB, por ser uma Instituição Federal, não se enquadra nesse padrão. A Diretoria, em resposta a esse parecer, relatou que BPM não é uma metodologia, mas uma área de conhecimento que diz respeito a qualquer organização que queira alcançar e se orientar para um modelo de gestão de excelência, e que o termo business não está relacionado à custos ou lucros financeiros, e sim ao negócio da Instituição, que visa fornecer valor ao cliente por meio da interação entre as pessoas. A cada trâmite desse processo, passa-se em torno de um a dois meses, atrasando substancialmente a contratação da consultoria. A última informação fornecida pela Diretoria foi a de que, em uma reunião do Decano de Planejamento e Orçamento com o procurador da PJU, esse processo fosse considerado como prioridade, tendo em vista que se trata de uma iniciativa com a ciência do Reitor e pertence ao planejamento estratégico da Instituição. Caso o posicionamento seja favorável, o próximo passo será a contratação da consultoria.

Desses três marcos temporais, esta pesquisa analisa a situação atual de como a DPR está implementando a gestão por processos na Instituição de maneira gradual, por meio de uma metodologia própria, aplicada nas unidades organizacionais demandantes ou identificadas pela alta administração. Essa metodologia inicia-se pela ambientação, passando pela análise e desenho do processo e finalizando com o acompanhamento e revisão.

\subsection{ORIGEM DA GESTÃO POR PROCESSOS}

Os resultados nesta categoria de análise dizem respeito às informações que constam no Apêndice B. Diante dos dados dispostos nesse quadro, observa-se que a origem da gestão por processos na UnB ocorreu da necessidade de se adotar um novo modelo de gestão que proporcione à Instituição ter uma gestão mais flexível e eficiente, gerando um serviço de melhor qualidade no atendimento às necessidades do cidadão. Para isso, várias medidas foram proporcionadas como:sensibilização da alta administração e demais areas; disseminação da cultura de gestão por processos; institucionalização do modelo; criação do escritório de processos; utilização de uma metodologia para mapeamento de processos; e formação e capacitação de equipe.

A adoção da visão centrada em processos pela organização é importante pois, segundo Gonçalves (2000), a ênfase anteriormente dada aos departamentos da estrutura e às 
tarefas isoladas migrou para um modelo mais simples e dinâmico que permite enxergar o fluxo contínuo de atividades encadeadas que começam e terminam no cliente.

Traçando um paralelo cronológico sobre a origem da gestão por processos na UnB, o Relatório de Gestão da UnB de 2011 (Doc4, 2012, p.24;116), descreve a gestão de processos como um dos objetivos estratégicos: “(...) ter excelência e transparência (...) na gestão de processos”, tendo como meta “(...) documentar os processos organizacionais críticos até 2015” e para o seu alcance está a ação de “(...) envolver as Unidades nas ações de identificação, mapeamento, desenho e documentação dos processos organizacionais". Porém, analisando esse relatório não foi possível identificar se houve alguma tentativa de implantação da gestão por processos na Universidade no ano de 2011. A inconsistência encontrada está relacionada ao fato de que, apesar da DPR ter sido criada em 18/03/2011, conforme Ato da Reitoria $n^{0}$ 385/2011 (Doc2), não consta nesse relatório qualquer referência à Diretoria e suas responsabilidades pelos processos organizacionais.

No Relatório de Gestão da UnB de 2012 (Doc5, 2013, p.25), cita-se que "foram identificados os macroprocessos das Unidades por meio dos documentos identificados pelas unidades organizacionais, quando da formalização do pedido, encaminhado ao Decanato de Gestão de Pessoas (DGP), para análise e concessão da flexibilização da jornada de trabalho. (...) constava a matriz de gerenciamento de processos, na qual as Unidades identificavam seus processos e os resultados desses processos...”. Nesse Relatório, a DPR é inserida no DPO, como unidade responsável pelos processos organizacionais, bem como o resultado dos seus mapeamentos. Porém, nada consta nesse relatório em relação às ações desenvolvidas para o alcance do objetivo e meta traçados no relatório de 2011, dessa forma, infere-se que não há o devido acompanhamento e avaliação dos resultados, dificultando a identificação do que foi e do que precisa ser melhorado.

O Relatório de Gestão da UnB de 2013 (Doc6, 2014, p.36), consta que "a UnB não se encontra orientada pela visão por processos e, sendo assim, não dispõe de um modelo de governança desses processos, definindo papéis e responsabilidades, padrões e mecanismos de controle e avaliação, o que propiciaria o acompanhamento e melhoria dos mesmos". Corroborando com essa descrição do relatório, encontra-se a verbalização do $\mathrm{E}_{1}$ : "Quando foi criado o DPO (...), por algum tempo, nós ainda trabalhamos mapeando processos de forma isolada, quer dizer, sem o necessário alinhamento com planejamento estratégico, com indicadores de desempenho de processos vinculados aos indicadores de planejamento e outros pontos de integração que seriam necessários como o modelo de governança com constituição de papéis, responsabilidade com os envolvidos, TI, gestores de processos nas unidades, 
políticas, definição de uma instância de discussão em torno do tema 'processos' para dar sustentabilidade à unidade criada".

No Relatório de Gestão da UnB de 2014 (Doc7, 2015, p.26) tem-se a informação de que "a gestão por processos não é o enfoque direcionador da Instituição, porém foram levadas a efeito algumas iniciativas nesse sentido como: modelagem de alguns processos de apoio e disseminação da visão por processos na Instituição”. O PDI 2014-2017 (Doc1, 2014, p.27), ratificado pelo Relatório de Gestão de 2014 (Doc7, 2015, p55), relatam que ao discriminar os objetivos e estratégias da Universidade, encontra-se a

\begin{abstract}
implantação da gestão por processos e, para isso, algumas estratégias foram traçadas como: definir o modelo de governança de processos; elaborar programa de capacitação em gestão por processos para gestores e executores; estabelecimento de metodologia e padrões para mapeamento e modelagem de processos; disseminar a cultura da visão por processos; estabelecer mecanismos de publicação de processos (portal dos processos); estabelecer alinhamento entre T.I e negócios; e políticas e metodologias e padrões para desenvolvimento de soluções de TI (; Doc1, 2014, p.27).
\end{abstract}

Analisando os Relatórios de Gestão (Doc4; Doc5; Doc6; Doc7) e a verbalização do Entrevistado $1\left(\mathrm{E}_{1}\right)$ : "Em outubro de 2013, quando eu assumi a Direção, eu pensei bom quem sabe agora é a oportunidade da gente considerar realmente o papel da Diretoria como escritório de processos. Então, começamos com várias iniciativas nesse sentido", infere-se que a preocupação em se adotar o modelo de gestão por processos ficou mais evidente a partir do ano de 2013. A falta de conhecimento em relação à gestão por processos é constatada no relatório de 2012, em que foi produzida uma matriz de gerenciamento de processos sem padrões e metodologia definidas, por uma área que não era responsável por processos, no caso, o DGP, sendo que a DPR, responsável pelos processos organizacionais, fazia parte da estrutura organizacional desde 18/03/2011, conforme informação do próprio relatório. Outra questão, é a falta de continuidade nas informações contidas nos Relatórios em relação aos processos, pois o que foi programado em um ano, não consta se foi ou não alcançado no ano seguinte.

A sensibilização e o apoio da Alta Administração, exaltados por Laurindo e Rotandaro (2015), em relação à importância da adoção do modelo de gestão por processos na Universidade, ocorreu em um evento, conforme a verbalização do E1: "Houve um evento para concepção do planejamento estratégico da UnB. Nesse evento a diretoria teve oportunidade de expor a gestão por processos e nessa oportunidade que o Reitor institucionalizou esse modelo de gestão", por meio da sua institucionalização pelo Reitor, segundo consta no PDI 20142017 (Doc1, 2014) e no Memorando n ${ }^{0}$ 77/2014/DPO (Doc3, 2014). A confirmação pelo 
Reitor, desse modelo, foi extremamente importante para o surgimento oficial e disseminação do novo modelo adotado no âmbito da Instituição.

Para uma maior disseminação da cultura da gestão por processos, houve a tentativa de contratação da consultoria da profa. Angela Brodbeck, responsável pela implantação desse modelo na UFRGS, por meio do escritório de processos, conforme as verbalizações dos entrevistados $\mathrm{E}_{1}$ : “(...) contratação da consultoria dessa professora para nos ajudar a implantar a gestão por processos na UnB...” e $E_{10}$ : “(...) Nesta palestra foi evidenciada a necessidade de ter processos, metodologia para implementar processo e ferramentas para quebrar a cultura de resistência na adoção de uma nova tecnologia de gestão. (...) foi mostrada toda a metodologia de como deveria implementar a gestão por processos". Porém, o processo encontra-se parado na PJU da UnB desde julho de 2014. Seguindo esse pensamento, de disseminar a visão de processos, a DPR tomou algumas iniciativas, conforme descrito em seus Boletins Informativos de 2013 e 2014, como: projeto de reestruturação da Diretoria; apresentação de proposta de metodologia para mapeamento de processos; realização de workshop; proposta de capacitação para servidores; elaboração da proposta para implantação da gestão por processos etc.

Dentre todos os fatores que deram origem a gestão por processos nas Instituições Públicas, há a exigência legal de maior transparência, conhecimento e publicidade dos processos, conforme Dixon (2012), Baldam, Valle e Rozenfeld (2014) e as verbalizações dos entrevistados $E_{2}$ : “(...) basicamente exigência legal mesmo...”e $E_{4}$ : “(...) exigência, por parte do Governo Federal, de maior transparência nos processos, de maior conhecimento e publicidade desses processos”, é amparada pelo Decreto 6.932, de 11/08/2009, que dispõe sobre a simplificação no atendimento público prestado ao cidadão, e pela Lei 12.527 , de 18/11/2011, que obriga órgão e instituições públicas a fornecerem informações sobre seus processos de modo a fortalecer a participação do cidadão, permitindo o acesso e conhecimento dos seus direitos essenciais. Por ser uma instituição pública de ensino superior, a adequação da UnB às normas legais, contribuiu para o surgimento dessa gestão. Dessa forma, o fluxo dos seus processos será conhecido tanto internamente, como externamente.

Fatores abordados e apontados como causas por Laurindo e Rotandaro (2006). Smith e Fingar (2007), Pradella, Furtado e Kipper (2012), e de acordo com as verbalizações dos entrevistados $\mathrm{E}_{5}$ : "A origem começou com o processo de horizontalização da DAIA, com o intuito de melhorar o fluxo dos processos e agilizar o atendimento para o cidadão.”; $\mathrm{E}_{7}$ : “(...) direção e o Decanato querem mudar o atendimento (...) e a forma que eles viram pra ver a possibilidade de implementar essa mudança seria pelo mapeamento...”; e $\mathrm{E}_{8}$ : “(...) fazer um 
mapeamento inicial de processos. (...) Esse mapeamento seria, em um primeiro momento, para identificar quais são as atividades que estão sendo desenvolvidas na Diretoria com fins de promover um melhor atendimento ao cidadão lá na ponta e, também contemplar, digamos assim, insatisfações da força de trabalho.”, contribuíram efetivamente e foram responsáveis para a origem da gestão por processos: interesse da chefia; necessidade de melhoria no atendimento ao cidadão; necessidade de melhoria dos fluxos dos processos; mudança para uma visão horizontalizada; interesse em conhecer e identificar as atividades desenvolvidas nos departamentos; e mapeamento inicial de processos.

Segundo Paim (2009), Tregear, Jesus e Macieira (2010), Albuquerque e Rocha (2006), a criação do escritório de processos é considerada como uma ação colaborativa para a origem da gestão por processos e o instrumento para sua institucionalização. A UnB não possui em sua estrutura organizacional um setor ou departamento com a nomenclatura 'Escritório de Processos', o que se tem é a Diretoria responsável pelos processos organizacionais, que coordena e orienta esses processos, utilizando-se de metodologia própria, exercendo todas as atividades cabíveis ao modelo de escritório adotado nas organizações.

Apesar da sua criação ter sido em 2011, os trabalhos da Diretoria só começaram efetivamente a partir de 2013 e, esse modelo de gestão, só foi institucionalizado oficialmente na Universidade em 2014. Sendo assim, pode-se afirmar que antes da institucionalização, a DPR contribuía apenas para promover o modelo e, a partir de 2014, passou a ser a garantia de que as práticas do gerenciamento de processos da Universidade serão mantidas na busca de soluções para os problemas organizacionais relacionados aos processos. Essa afirmação pode ser constatada pelo PDI 2014-2017 (Doc1, 2014) que trata do propósito da DPR: “disseminar e realizar práticas que promovam a melhoria contínua dos processos estratégicos da Instituição, fazendo uso de metodologias e ferramentas que permitam o conhecimento e a transparência dos processos executados, de modo a atender a atual necessidade do serviço público de implementação de modernas abordagens administrativas".

O PDI 2014-2017 (Doc1, 2014) consiste num documento em que se definem a missão e visão de futuro da instituição de ensino superior e as estratégias para atingir suas metas e objetivos, abrangendo um período de quatro anos. Trouxe informações importantes a respeito da UnB, como: definição da missão e visão de futuro; foco de atuação; identificação dos elementos relacionados ao ambiente interno e externo; pontos fortes e fracos; e oportunidades e ameaças. Dentre os pontos fracos encontrou-se a ineficiência dos processos administrativos e organizacionais, surgindo, assim, a necessidade de implantação da gestão por processos que, segundo Pradella, Furtado e Kipper (2012, p.6), é responsável por 
"melhorar de forma contínua os processos organizacionais" e pela busca da satisfação do cliente, conforme Hammer (2004).

$\mathrm{Na}$ busca de um modelo de gestão capaz de se adequar às mudanças sociais, políticas e tecnológicas, ou seja, que possua: estrutura flexível; qualidade nos serviços prestados; melhoria contínua dos processos organizacionais; integração entre sistemas de informação; e interdependência entre departamentos - originou-se a gestão por processos. Diante disso, as ações e estratégias apresentadas por Cunha (2012) e De Sordi (2012) corroboram com as motivações apresentadas para o surgimento da gestão por processos na UnB.

\subsection{PROPÓSITOS ESTRATÉGICOS PARA ADOÇÃO DA GESTÃO POR PROCESSOS}

Os resultados nesta categoria remetem às informações que constam no Apêndice C. De maneira geral, a adoção da gestão por processos pelas organizações tem por objetivo mapear os processos organizacionais, estipular melhorias e monitorá-los com foco no alcance dos resultados e cumprimento dos seus desafios institucionais. As organizações, respeitadas as suas especificidades, possuem propósitos para implantar esse modelo que vão desde o conhecimento dos próprios processos até o alcance da excelência em gestão.

O PDI 2014-2017 (Doc1, 2014) e o Relatório de Gestão 2014 (Doc7, 2015) apresentam uma redefinição da missão e visão de futuro da UnB. Em ambas fica evidente a busca pela excelência, tanto acadêmica, científica e tecnológica como em gestão por processos. O propósito estratégico de alcançar o modelo de excelência em gestão, é constatada na verbalização do entrevistado $\mathrm{E}_{1}$ : "Eu acho que a coisa principal é realmente o alcance dessa visão de futuro da UnB que é colocar a UnB, a Universidade de Brasília, como universidade da capital do país, uma universidade reconhecida nacionalmente, que ela seja reconhecida também internacionalmente, (...) A UnB mereceria estar num patamar mais elevado de excelência. (...) a visão de futuro é colocá-la entre as melhores universidades do país atendendo à critérios de excelência. Para que a UnB alcance isso é necessário que a missão da UnB seja cumprida no dia a dia, (...) a missão da UnB só é cumprida por meio dos seus processos, caso eles sejam acompanhados e estejam alinhados ao planejamento estratégico. Esse é um instrumento que a UnB tem para se direcionar, para se guiar, até mesmo mudar os seus rumos, se ela verificar que a sua missão não está indo ao encontro do atingimento da sua visão...".

No Brasil, a busca pela excelência em gestão pública ganhou notoriedade com o Programa Nacional de Gestão Pública e Desburocratização - GESPÚBLICA (BRASIL, 2005) 
e a publicação do Modelo de Referência em Gestão Pública (BRASIL, 2014), criado pelo Decreto $n^{0} 5378$, de 23 de fevereiro de 2005, que foi considerado um novo modelo de gestão e tem por propósito contribuir para a qualidade dos serviços e para a geração de ganhos sociais. O Manual de Gestão por Processos do Ministério Público Federal (BRASIL, 2013), constata que a adoção da gestão por processos potencializa diretamente o desempenho da Instituição, primando pela excelência organizacional e agilidade nos negócios. Dessa forma, infere-se que o propósito em alcançar excelência em gestão significa que, por meio da adoção da gestão por processos, a UnB estará preparada para a prestação de serviços de qualidade que atendam às expectativas dos clientes (internos e externos) de modo satisfatório, utilizando-se de estrutura leve, flexível, ágil, descentralizada e integrada horizontalmente, com objetivos e metas definidos, responsáveis pelos processos identificados e capacitados, utilizando-se de uma política de avaliação dos resultados

No PDI 2014-2017 (Doc1, 2014), juntamente com o Relatório de Gestão 2014 (Doc7, 2015), constam as estratégias traçadas para o cumprimento da implantação da gestão por processos. Definir o modelo de governança dos processos é umas das estratégias que também foi corroborada como propósito estratégico para a adoção da gestão por processos pelos entrevistados: $\mathrm{E}_{2}$ : “(...) tem a questão de como as coisas são feitas mesmo, das necessidades de sistemas, de automação ou de estrutura física...”; $\mathrm{E}_{3}$ : “(...) A parte da governança, a questão de tentar melhorar os processos. Eu vejo que isso é algo extremamente estratégico para a instituição..."; reafirmando a necessidade de estabelecer essa governança, o Relatório de Gestão 2013 (Doc6, 2014) relata que "a UnB não se encontra orientada pela visão de processos e, sendo assim, não dispõe de um modelo de governança desses processos $(\ldots)$ ".

Por governança de processos, entende-se, segundo Santos (2014), “o conjunto de melhores práticas que garante: a tomada de decisões certas pelos gestores responsáveis; e direcionamento da gestão de processos nas organizações de forma a viabilizá-la como um elemento organizacional capaz de contribuir para um efetivo aumento da performance dos processos e, consequentemente, da performance da organização". Sendo assim, infere-se que o estabelecimento do modelo de governança dos processos na UnB é crucial, pois não basta existir a visão por processos na Instituição, é necessário que exista a gestão desses processos, o que significa estabelecimento de papéis e responsabilidades de todos os envolvidos no gerenciamento desses processos. Para tanto, Jesus e Macieira (2014), Baldam, Valle e Rozenfeld (2014), Paim et al. (2009) e Santos (2014), afirmam que se deve estabelecer uma unidade organizacional, responsável por essa governança, que será denominada de 'escritório 
de processos'. No caso da Universidade de Brasília, a Diretoria de Processos Organizacionais é responsável pelos métodos, técnicas e ferramentas de gerenciamento de processos na instituição.

A proposição de implementação de melhorias é evidenciada no PDI 2014-2017 (Doc1, 2014), que especifica como política da UnB voltada para a melhoria dos processos institucionais a criação da DPR, e no Memorando $n^{0}$ 77/2014/DPO (Doc3, 2014), no qual consta o conhecimento dos processos organizacionais pelas unidades da UnB e consequente implementação de melhorias. Reafirmada, também, nas verbalizações dos entrevistados $E_{2}$ : “(...) Com relação à questão estratégica, eu acho que é a questão das melhorias (...) Entender o que se faz para se saber propor melhorias. Não melhorias óbvias. (...) Melhorias inteligentes, pensadas (...)"; $\mathrm{E}_{3}$ : "Primeiro, a gestão por processos é extremamente estratégica para a instituição (...) A universidade precisa conhecer seus processos, isso é algo muito visível, e precisa melhorar esses processos...”; $E_{5}$ : "É melhorar o atendimento...”; $\mathrm{E}_{6}$ : “(...) comprovar (...) que o atendimento, o tempo todo, ininterrupto, que seria vantagem"; E9:"Melhorar a qualidade da gestão administrativa, a gente percebe que tem muito problema de retrabalho, muita situação em que decisões levam muito tempo para serem executadas ou tomadas, porque tem todo um mandamento dentro da Universidade que não está claro, as vezes, não está adequado a essas necessidades, então, é questão de melhoria e eu acho que até uma coisa mais ampla, (...) melhoria da qualidade dos gastos públicos, no fundo é isso. Quer dizer, você melhora os processos e, com isso, você melhora a quantidade, a saída dos produtos que você tem com aqueles mesmos recursos, é basicamente isso."

Paim et al. (2009) e Baldam, Valle e Rozenfeld (2014) são unânimes em afirmar que o gerenciamento por processos é um habilitador de melhorias. Para Laurindo e Rotandaro (2006), a gestão por processos pode ser entendida como um enfoque de desenvolvimento organizacional que tipicamente objetiva alcançar melhorias qualitativas de desempenho na gestão, tomando uma visão objetiva e sistêmica das atividades, estruturas e recursos necessários para cumprir os objetivos críticos do negócio.

Segundo o Manual de BPM CBOK (2013), as organizações gerenciadas por processos estão preparadas para as transformações e desafios e, por meio de uma medição efetiva de processos, encontram-se capacitadas para controlar os gastos e a qualidade dos serviços prestados. Fazem parte das vantagens da criação do escritório de processos em uma Instituição: otimização de recursos para o estudo de melhoria de processos e evitar o retrabalho no fluxo dos processos. Portanto, com a adoção da gestão por processos pela UnB se busca alcançar a melhoria contínua de processos, serviços, atendimento, gastos etc.; 
eliminando redundâncias e atividades em duplicidade, que não agregam valor ao serviço, reduzindo os custos e prevenindo os erros. Assim como na governança de processos, os procedimentos relacionados às melhorias dos processos encontram-se sob a responsabilidade do escritório de processos.

Segundo Jesus e Macieira (2014), conhecer o fluxo dos processos e seus responsáveis na organização é um dos propósitos estratégicos para se adotar a gestão por processos. Essa afirmação foi mencionada nas verbalizações dos entrevistados: $\mathrm{E}_{3}$ : “(...) A universidade é uma instituição extremamente carente de até conhecer os seus próprios processos, ela nem sabe muitas vezes como eles são realizados (...) Quem é responsável pelo o que (...)"; E 4 : "O primeiro propósito é trazer uma maior organização dos processos e um maior conhecimento dos processos de um modo geral. Então, a primeira grande conquista da gestão por processos será essa maior integração entre as areas, conhecimento dos processos ponta a ponta.”; $E_{8}:$ “(...) identificar essas necessidades e esses problemas, porque, a partir do momento que se identificou essas atividades (...) tem como caracterizar o cenário atual da gente, a situação atual e, depois, a situação futura. Então, já na situação atual a gente já identificou algumas necessidades (...); $\mathrm{E}_{10}$ : “(...) apenas sei que o TCU está exigindo a criação de escritório de processos para que mantenham os processos organizacionais em uma base de conhecimento...”; e, de acordo com o PDI 2014-2017 (Doc1, 2014), é um dos propósitos da DPR utilizar metodologias e ferramentas que permitam o conhecimento e a transparência dos processos executados pela Universidade de Brasília.

Para o Manual de BPM CBOK (2013), Gonçalves (2000) e Albuquerque e Rocha (2006), o fluxo dos processos podem ser gerenciados e conhecidos por todos quando o foco da organização está voltado para os processos, sendo seus responsáveis (donos de processos, gerente de processos etc.) identificados.Segundo Paim et al. (2009), tanto o fluxo dos processos, como a definição de seus responsáveis, são atividades pertinentes ao escritório de processos, ratificando a importância de sua criação para o desempenho dos processos e desenvolvimento da Instituição. Portanto, ter essa visão de como os processos fluem e funcionam, permite transparência das informações e garantia de que os serviços terão continuidade, independentemente, se os funcionários responsáveis permaneceram ou não na organização, tendo em vista a rotatividade de pessoal e os casos de aposentadoria.

A verbalização do entrevistado E1: “(...) a gestão por processos (...) não somente ajuda a instituição a se ver (...), como ela propicia que as próprias pessoas se vejam de formas diferentes. BPM permite que as pessoas pensem na qualidade do que ela própria executa. $\mathrm{Na}$ medida em que você consegue enxergar de que forma ajudar melhor a outra unidade, a 
responsabilidade aumenta, tanto para os gestores como para aquelas pessoas que executam o processo (...) faz as pessoas meditarem e reflexionarem sobre a qualidade do seu próprio trabalho. Isso quer dizer o que? Crescimento individual, não só profissional, crescimento como pessoa".

É importante para enfatizar a importância das pessoas na gestão por processos, pois, segundo Davenport (1994), a adoção da gestão por processos é um alinhamento entre pessoas, estratégia e tecnologia. Portanto, ter o crescimento individual e profissional é um propósito a ser alcançado para a organização que almeja a adoção desse novo modelo de gestão. Tanto que, o PDI 2014-2017 (Doc1, 2014) e o Relatório de Gestão 2014 (Doc7, 2015), apontam como uma das estratégias para essa implantação, a elaboração de programa de capacitação em gestão por processos para gestores e executores. Reforçados por De Sordi (2012), o Manual de BPM CBOK (2013), Baldam, Valle e Rozenfeld (2014) e Albuquerque e Rocha (2006) que salientam a importância dessa capacitação. Dessa forma, não há como adotar esse novo modelo se a organização não capacitar seus servidores para utilizar a metodologia e padrões para mapeamento e modelagem dos processos, fazendo com que se sintam responsáveis pelos processos e sua gestão.

$\mathrm{Na} U \mathrm{UnB}$, algumas ações de capacitação propostas pela equipe da DPR, foram relatadas nos Boletins Informativos da DPR (Doc8, 2014; Doc9, 2015), como: workshop "Encontro com a UnB - Planejamento Estratégico: Alinhamento entre Ações estratégicas, Processos e Iniciativas de Tecnologia da Informação"; Curso de Análise e Melhoria de Processos BPM Day Três Poderes; Curso de Formação de Analista de Processos (Gart Capote) - módulo 01; Curso de Formação de Gestores de Processo; Curso de Formação de Analistas de Processos (Gart Capote) - módulo 01; Seminário Internacional de BPM; Participação no Workshop sobre o SIG/UFRN; Evento BPM Day Educação 2014;e III Workshop sobre Gestão de Documentos da UnB.

O propósito de integração entre as unidades organizacionais pode ser sintetizado à horizontalização dos processos, pois a adoção da gestão por processos implica em analisar os processos de forma transversal, evitando que as áreas trabalhem de forma isolada. Esses propósitos foram constatados nas verbalizações dos entrevistados $\mathrm{E}_{4}$ : “(...) A gente tem hoje (...) uma falta de comunicação entre as unidades executoras dos processos, tudo muito departamentalizado e focado naquilo que é exercido naquela caixinha. Então, a primeira grande conquista da gestão por processos será essa maior integração entre as áreas...”; E5: "É melhorar o atendimento e passar pelo processo de horizontalização (...) que hoje é departamentalizado e a direção quer que seja horizontalizado”; E7: “(...) Esse mapeamento, eu 
acredito, que é até para ver a possibilidade de ele (setor) entrar nessa horizontalidade (...) de atendimento...”; $\mathrm{E}_{8}$ : “(...) A gente consegue desenvolver muito bem o serviço que a gente tem (...) porém, a gente não consegue ainda se comunicar com as unidades acadêmicas, quiçá com outros campi...".

No Relatório de Gestão 2013 (Doc6, 2014) consta, deforma clara, que ao identificar os responsáveis pelos macroprocessos e seus processos procura-se incorporar a característica de interfuncionalidade oferecida pela visão por processos.Esse relato corrobora com a perspectiva da gestão por processos, apresentada por Gonçalves (2000), de tornar a integração intra e interorganizacionais fatores importantes para o alcance de diferenciais frente às outras organizações. Segundo Laurindo e Rotandaro (2006), a organização horizontal aumenta a eficiência e eficácia dos processos, além da velocidade de resposta ao mercado pelas organizações. Infere-se que com a adoção dessa gestão, a comunicação e a falta de integração entre as unidades organizacionais da UnB não sejam mais barreiras na execução do fluxo de atividades. A gestão, que antes era departamentalizada, passa a ser horizontal, o que não significa mudar a estrutura funcional, pois as áreas funcionais continuam existindo, porém com uma visão voltada aos processos da organização.

Apesar do entrevistado $\mathrm{E}_{10}$ afirmar que o Tribunal de Contas da União está exigindo a criação pelas instituições públicas do escritório de processos, $\mathrm{E}_{10}$ : “(...) apenas sei que o TCU está exigindo a criação de escritório de processos para que mantenham os processos organizacionais em uma base de conhecimento...", não foi possível encontrar nenhuma legislação específica em relação a esse assunto. As normatizações encontradas do TCU definem as normas de organização das informações que devem ser prestadas anualmente por meio de Relatório e a exigência de identificação dos macroprocessos (finalísticos, de apoio e críticos)pelas instituições públicas.

Diante dessa categorização - propósitos estratégicos para adoção da gestão por processos -, é evidente que todos esses propósitos apontados corroboram para a adoção da gestão por processos pela UnB. Mais do que adotar esse modelo, a criação do escritório de processos é fundamental para o desenvolvimento e institucionalização dessa gestão. O ideal, para mudança de uma estrutura departamentalizada para uma por processos, é a instituição se organizar, de forma a elaborar um projeto voltado somente para a implantação dessa gestão, com apoio da alta direção, total transparência de informações e políticas de capacitação. A UnB começou a se organizar para adoção desse modelo ao criar a DPR que, apesar de não ter a nomenclatura de 'escritório de processos', exerce todas funções cabíveis a esse. Inclusive, o processo de institucionalização da gestão por processos na Universidade, foi desencadeado 
pelo trabalho da DPR junto à alta administração. Mapeamento de diretorias e promoção da importância da visão por processos estão entre as atividades que atualmente estão sendo desenvolvidas pela DPR.

\title{
4.4 METODOLOGIA PARA IMPLANTAÇÃO DA GESTÃO POR PROCESSOS
}

Por meio da gestão por processos, as instituições funcionam e criam valor a partir do gerenciamento dos próprios processos. Para tanto, é necessário que esses sejam transparentes para todos os envolvidos e que os participantes entendam a importância de integração entre as unidades, tendo em vista que o conhecimento do processo como um todo e a compreensão de como as atividades são executadas contribuem para o alcance dos objetivos organizacionais. Para a implementação dessa gestão, não há uma metodologia padrão, cada organização cria ou utiliza a que mais se adequa aos propósitos estratégicos, baseando-se em modelos como o de Albuquerque e Rocha (2006). O PDI 2014-2017 (Doc1, 2014), relata que:

\begin{abstract}
a DPR tem como propósito disseminar e realizar práticas que promovam a melhoria contínua dos processos estratégicos da instituição, fazendo uso de metodologias e ferramentas que permitam o conhecimento e a transparência dos processos executados, de modo a atender a atual necessidade do serviço público de implementação de modernas abordagens de gestão.
\end{abstract}

Desde 2014, a DPR desenvolveu uma metodologia própria para a implementação da gestão por processos na Instituição, baseada na utilizada pela Universidade Federal do Rio Grande do Sul (UFRGS), de autoria da professora Ângela Freitag Brodbeck, a qual a DPR iniciou o processo de contratação para prestação de serviços de consultoria nessa área. As verbalizações dos entrevistados listadas no Quadro 4confirmam que a Universidade é detentora de uma metodologia.

Quadro 4: Verbalizações sobre metodologia de implantação da gestão por processos

\begin{tabular}{|c|l|}
\hline ENTREVISTADO & \multicolumn{1}{c|}{ VERBALIZAÇÃO } \\
\hline $\mathrm{E}_{1}$ & $\begin{array}{l}\text { "Essa que a gente tá usando, eu posso até passar o documento onde tem todas as fases e } \\
\text { as etapas das fases (...) no nosso site tem um documento chamado PDF escritório de } \\
\text { processos }(\ldots) \text { esse documento fala sobre a proposta que essa professora vai } \\
\text { implantar junto conosco }(. . .) \text { e oportunamente a gente vai colocar no site todos os } \\
\text { processos mapeados..." }\end{array}$ \\
\hline $\mathrm{E}_{2}$ & $\begin{array}{l}\text { "Quem desenvolveu a metodologia que a gente usa atualmente foi (...), nossa Diretora e é } \\
\text { uma metodologia bastante completa...”; }\end{array}$ \\
\hline $\mathrm{E}_{3}$ & $\begin{array}{l}\text { "(...) a metodologia (...) foi elaborada pela nossa diretora atual (...) e ela se baseou em } \\
\text { vários materiais, várias leituras que ela fez, livros...”; }\end{array}$ \\
\hline $\mathrm{E}_{4}$ & $\begin{array}{l}\text { "Na verdade, a gente tinha uma metodologia anterior que era baseada na GESPÚBLICA } \\
\text { do Ministério do Planejamento. Hoje a gente já está com outra metodologia. Todas } \\
\text { guardam características semelhantes principalmente as que são fundamentadas no que se } \\
\text { tem de teoria sobre conhecimento CBOK (ABPM CBOK) e outras fontes..." }\end{array}$ \\
\hline
\end{tabular}




\begin{tabular}{|c|l|}
\hline $\mathrm{E}_{9}$ & $\begin{array}{l}\text { "A gente vem adotando (...) eu não sei te dizer em tempos de história, mas a antiga } \\
\text { diretora (...) ela montou uma metodologia...". }\end{array}$ \\
\hline
\end{tabular}
Fonte: Elaborado pelo autor.

4.4.1 Fases da metodologia atual de transformação por processos

A metodologia atual utilizada na UnB para implementação da gestão por processos foi baseada no modelo de Albuquerque e Rocha (2006), detalhado no arcabouço teórico desta pesquisa, compreendendo cinco fases, apresentadas na Figura 7.

Figura 7: Metodologia de transformação por processos

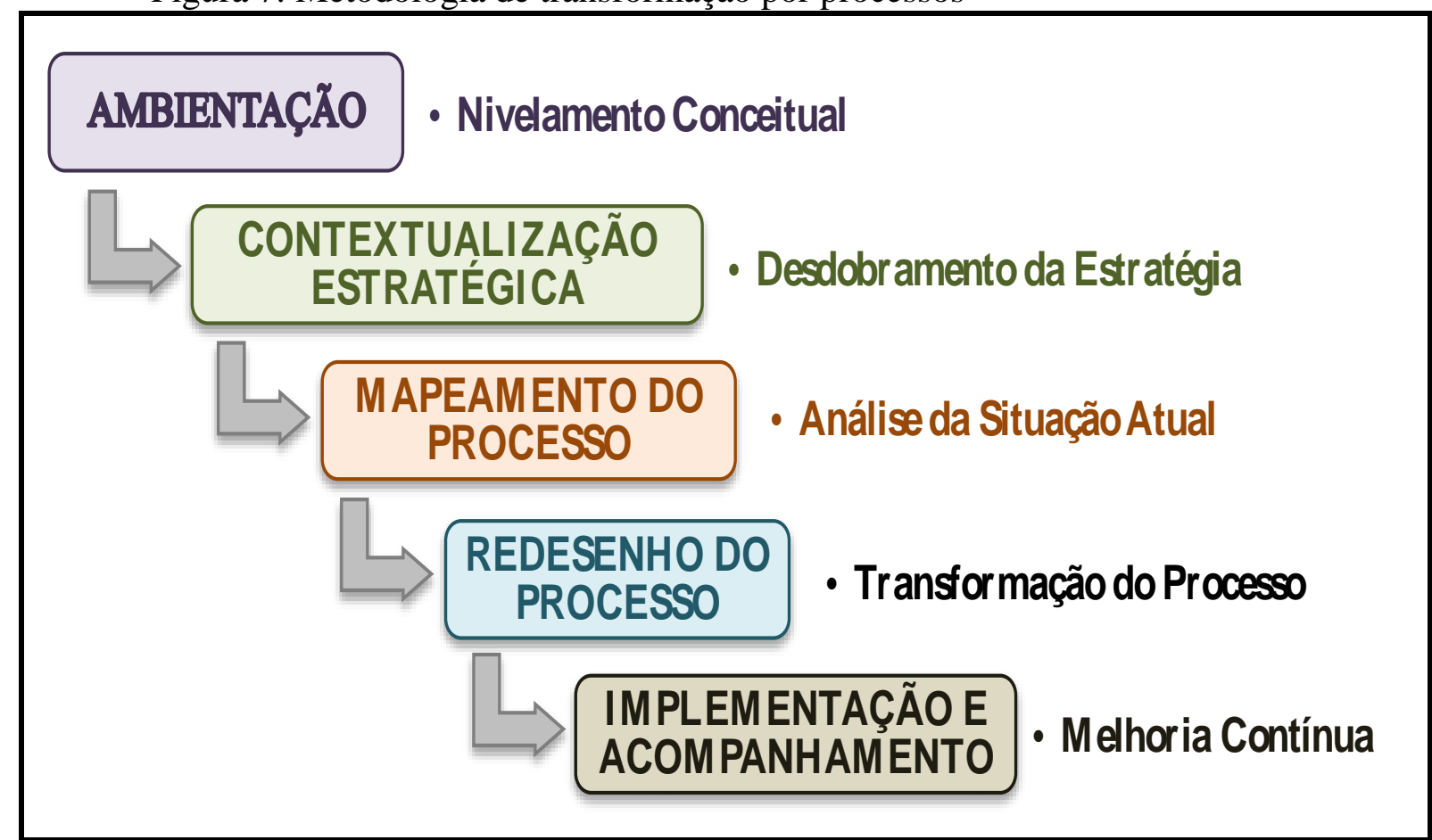

Fonte: Documento "Apresentando a Diretoria de Processos Organizacionais" elaborado pela DPR/DPO

A Fase 1 - Ambientação - é composta por três etapas, conforme a Figura 8. Cada etapa corresponde a uma providência que deve ser realizada para que se possa passar para a fase seguinte. 
Figura 8: Fase 1 - Ambientação

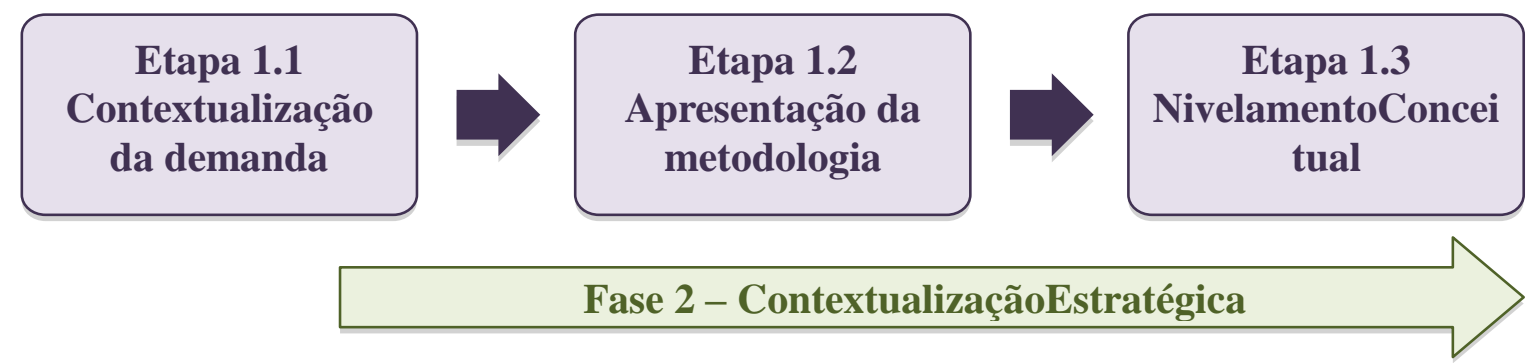

Fonte: Documento “Apresentando a Diretoria de Processos Organizacionais" elaborado pela DPR/DPO.

Nesta Fase de Ambientação, a DPR realizou uma reunião com a alta administração da UnB para contextualização da demanda, ou seja, nesta etapa a DPR apresentou a importância para a Instituição em se adotar a gestão por processos para o alcance da excelência na prestação de serviços e satisfação dos clientes.

Na etapa de apresentação e aplicação da metodologia a ser utilizada, apresentou-se esta metodologia de transformação por processos, dando ênfase às fases indicadas a seguir: mapeamento, redesenho, implementação e acompanhamento do processo. Para o nivelamento conceitual, apresentou-se o plano de capacitação das equipes com noções preliminares sobre gestão por processos, governança de processos, alinhamento estratégico e ferramenta BizAgiModeler ${ }^{1}$, por meio de cursos mensais de 40 horas e anual de 150 horas.

Finalizada a Fase 1, inicia-se a Fase 2 - Contextualização Estratégica -, conforme a Figura 9, composta pelas etapas de alinhamento estratégico, detalhamento dos macroprocessos, identificação dos processos críticos e priorização dos processos.

Figura 9: Fase 2 - Contextualização Estratégica

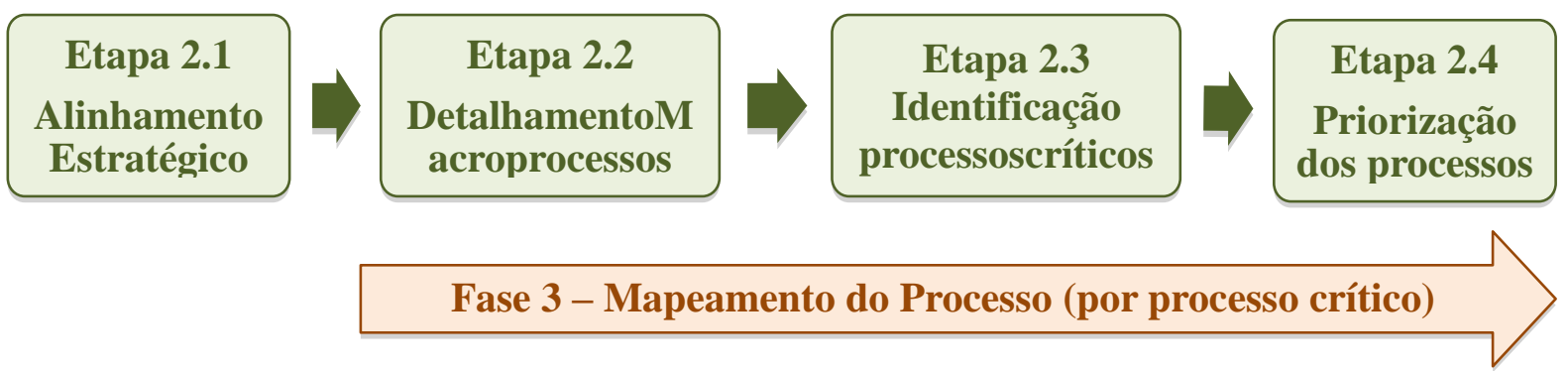

Fonte: Documento “Apresentando a Diretoria de Processos Organizacionais” elaborado pela DPR/DPO.

\footnotetext{
${ }^{1}$ Ferramenta utilizada para criação de fluxogramas, mapas mentais e diagramas em geral, permitindo aos usuários organizarem graficamente vários processos e as relações existentes em cada etapa. O software possui separadamente o módulo de modelagem, que é utilizado pela equipe da DPR, e o módulo servidor, que executa o processo.
} 
Na Etapa 2.1 - alinhamento estratégico - foi elaborado o mapa de contexto organizacional, no qual foi possível identificar as rupturas internas, ou seja, os problemas que comprometiam o desempenho da Instituição, interrompendo a interfuncionalidade entre as unidades organizacionais ou acarretando em retrabalho.

Dessa forma, foi possível separar quais processos eram passíveis de uma tomada rápida de decisão daqueles que eram críticos e necessitavam ser mapeados e redesenhados. $\mathrm{Na}$ Etapa 2.2, os macroprocessos finalísticos e de apoio da Instituição foram identificados. Essas duas etapas resultaram na Figura 10.

Figura 10: Contexto dos Macroprocessos Finalísticos e de Apoio

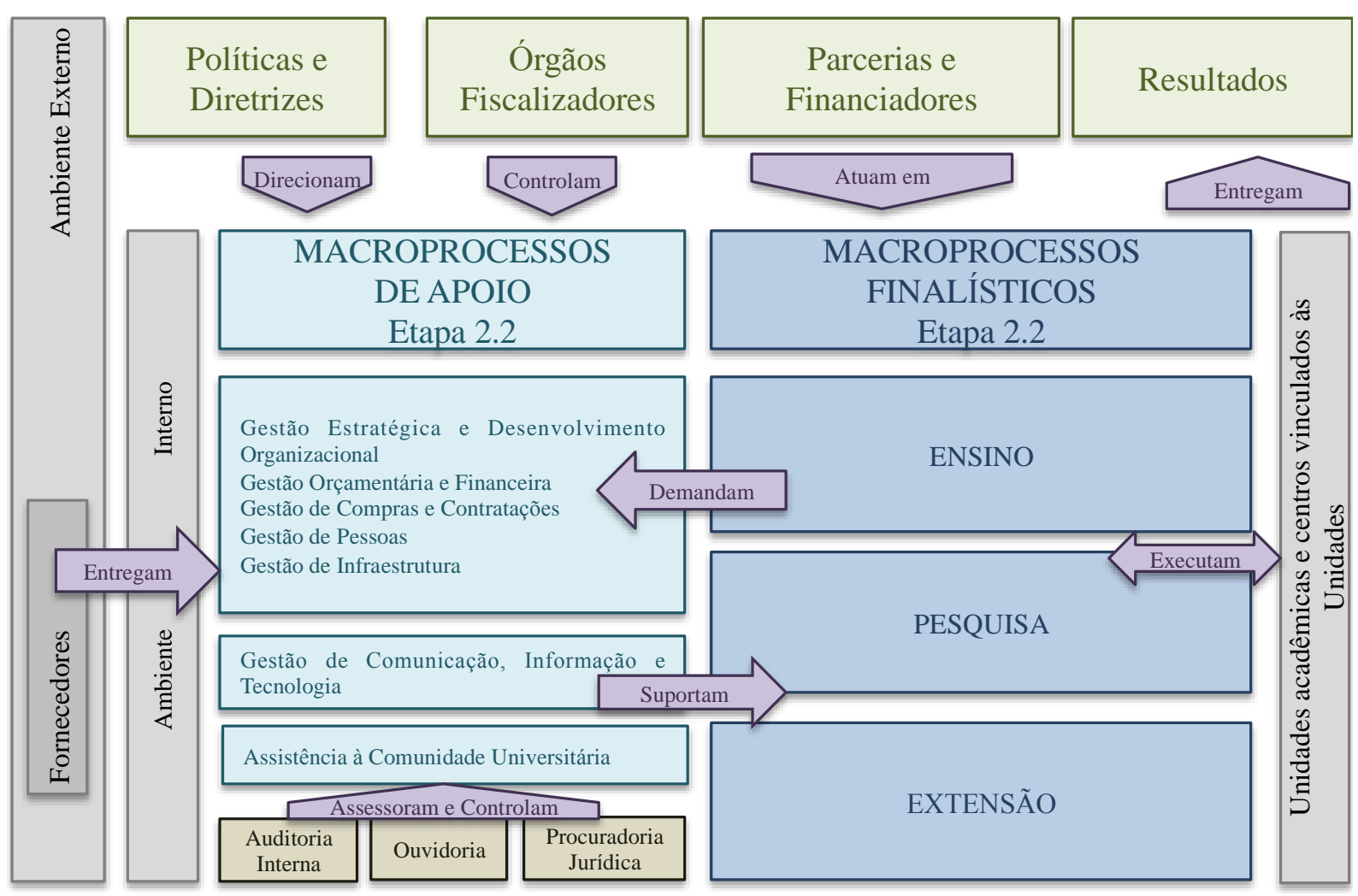

Fonte: Relatório de Gestão 2014 (Doc7, 2015), adaptado pelo autor.

Nesse contexto, conforme o Relatório de Gestão 2014 (Doc7, 2015), é possível ter uma visão sistêmica do funcionamento da $\mathrm{UnB}$, contendo as entidades que impactam na gestão. Identifica-se no ambiente externo: entidades controladoras da execução dos macroprocessos finalísticos e de apoio; entidades parceiras/financiadoras, que possibilitam a captação de recursos; entidades fornecedoras, que entregam produtos e serviços; e entidades que recebem resultados - sociedade em geral. No ambiente interno encontra-se: os macroprocessos de apoio, os quais visam dar suporte às entidades finalísticas; macroprocessos 
finalísticos, que determinam as necessidades de suporte das entidades de apoio; e as Unidades Acadêmicas e Centros vinculados, que são responsáveis pela execução dos macroprocessos finalísticos. São identificados, igualmente, os órgãos de controle interno e assessoria aos macroprocessos.

Os macroprocessos de apoio da UnB identificados pela DPR são compostos pelas Gestões: Estratégica e Desenvolvimento Organizacional; Orçamentária e Financeira; Compras e Contratações; Pessoas; Infraestrutura; Comunicação, Informação e Tecnologia; e Assistência à Comunidade Universitária.Sendo que os finalísticos correspondem às suas grandes funções, para as quais estão voltadas as unidades internas e descentralizadas, que são: ensino, pesquisa e extensão.

Ainda na Fase de contextualização estratégica, a Etapa 2.3 corresponde à identificação dos processos críticos de cada área estratégica que compõem os macroprocessos de apoio e finalísticos pela alta administração da UnB. Com essa identificação, passa-se para a matriz de priorização e macro fluxos dos processos (Etapa 2.4). Cada um dos processos resultará em um portfólio de projetos, ou seja, cada processo crítico passará pelo mapeamento, redesenho, implementação e acompanhamento, conforme descrição das fases a seguir.

Identificados os macroprocessos finalísticos e de apoio e os processos críticos correspondentes a cada área estratégica de atuação, inicia-se a Fase 3, de mapeamento desses processos, composta de quatro etapas, identificadas na Figura 11.

Figura11: Fase 3 - Mapeamento do Processo

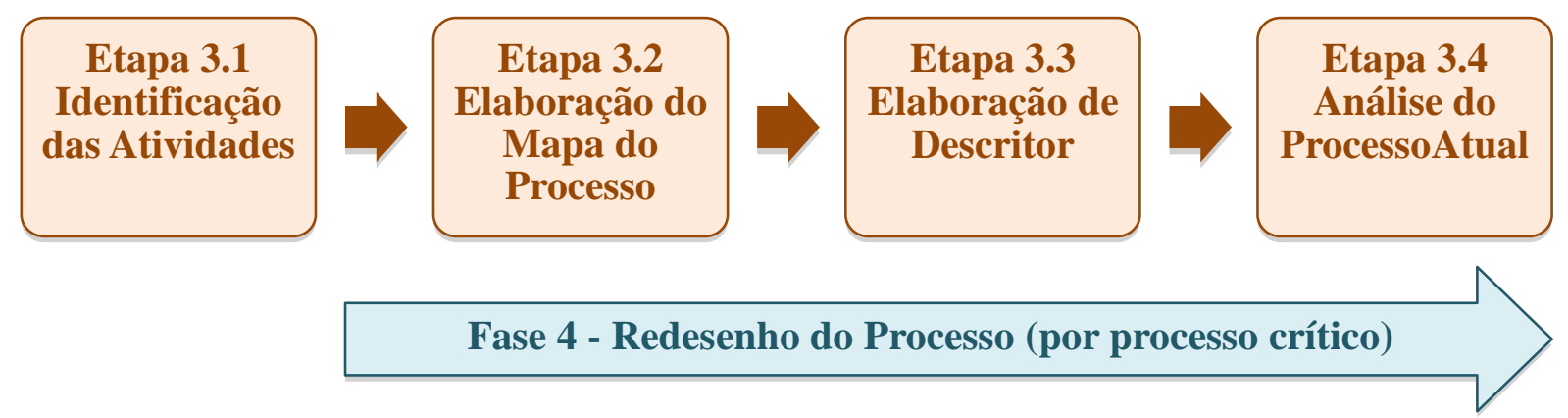

Fonte: Documento “Apresentando a Diretoria de Processos Organizacionais" elaborado pela DPR/DPO

A Etapa 3.1 corresponde a identificação de tarefas e subprocessos do processo crítico identificado pela alta administração, conforme verbalizações dos entrevistados: $\mathrm{E}_{2}$ “(...) é uma metodologia bastante completa (...) envolve diversos formulários, que a gente faz as reuniões 
e vai preenchendo os formulários junto com eles (setor). Então o primeiro é de identificação dos produtos e serviços daquele que a gente está mapeando. A partir dos produtos e serviços a gente preenche um de identificação de processos...”; $E_{3}$ “(..) a metodologia (...) já tem formulários desenvolvidos, principalmente para essa parte inicial, quando a gente começa a trabalhar com alguma unidade (...) A gente faz um levantamento dos processos primeiro...”; $\mathrm{E}_{5}$ "Bom, a gestão por processos nas coordenações começou com a descrição dos processos, passando por um fluxo no sistema Bizagi...";

$\mathrm{Na}$ Etapa 3.2, é elaborado o mapa de contexto atual do processo (As Is) utilizando o BizAgiModeler, possibilitando a visão macro desse processo por todos da Universidade, conforme identificado na verbalização do entrevistado $\mathrm{E}_{8}$ “(...) a que elas fizeram aqui (...) tem dado a situação atual do que é feito aqui ...”.

Após, elabora-se o descritor do processo (As Is), Etapa 3.3, que consiste na descrição de cada atividade do processo, com insumos e produtos, utilizando os artefatos do BizAgiModeler, essa etapa foi relatada nas verbalizações dos entrevistados: $\mathrm{E}_{2}$ “(...) da identificação dos processos (...) parte para identificação das atividades de cada um. Cada um dos processos tem um formulário (...). Depois que a gente faz a reunião, os formulários já estão preenchidos, de atividades, a gente faz o fluxo, faz o diagrama”; $\mathrm{E}_{3}$ “(...) tem um formulário posterior quando a gente já tem os processos definidos, a gente utiliza formulário de levantamento de atividades e a gente descreve as entradas, as saídas de cada atividade daquele processo (...) com base nesse formulário, já consegue trabalhar os fluxos utilizando a ferramenta Bizagi, que é o software que a gente usa...”; $E_{5}$ “(...) basicamente ela trabalha com o levantamento de informações dos processos a respeito das atividades, as entradas e saídas, como essas atividades são executadas e tudo isso a gente reúne no final em diagramas Bizagi e, através disso, a gente consegue propor melhorias...”; $\mathrm{E}_{7}$ “(...) Então, a gente tem reunião toda segunda e quinta, a manhã toda (...) inicialmente, para a gente fazer um levantamento das atividades que o meu setor faz. Aí a gente trouxe, teve uma orientação delas como fazer (...) as primeiras atividades, aquele primeiro formulário, e depois ela está fazendo com a gente o fluxo...";

$\mathrm{Na}$ etapa 3.4, elabora-se o mapa interfuncional do processo atual, em que será possível a visualização das unidades envolvidas nesse processo, o levantamento do desempenho, identificando as rupturas e estabelecendo melhorias. Antes de passar para a próxima fase, a análise do processo atual deve ser apresentada às areas envolvidas para que essas possam ratificar ou retificar as rupturas identificadas e sugerir melhorias, conforme 
descrito pelo entrevistado $\mathrm{E}_{2}$ “(...) volta com o pessoal, valida, faz as alterações que eles acharem necessárias e fazemos o descritor que é cada uma das caixinhas do Bizagi...”.

A Fase 4 consiste no redesenho do processo e tem por finalidade corrigir as rupturas identificadas no processo atual. Para tanto, são estabelecidas seis fases, conforme Figura 12.

Figura 12: Fase 4 - Redesenho do Processo

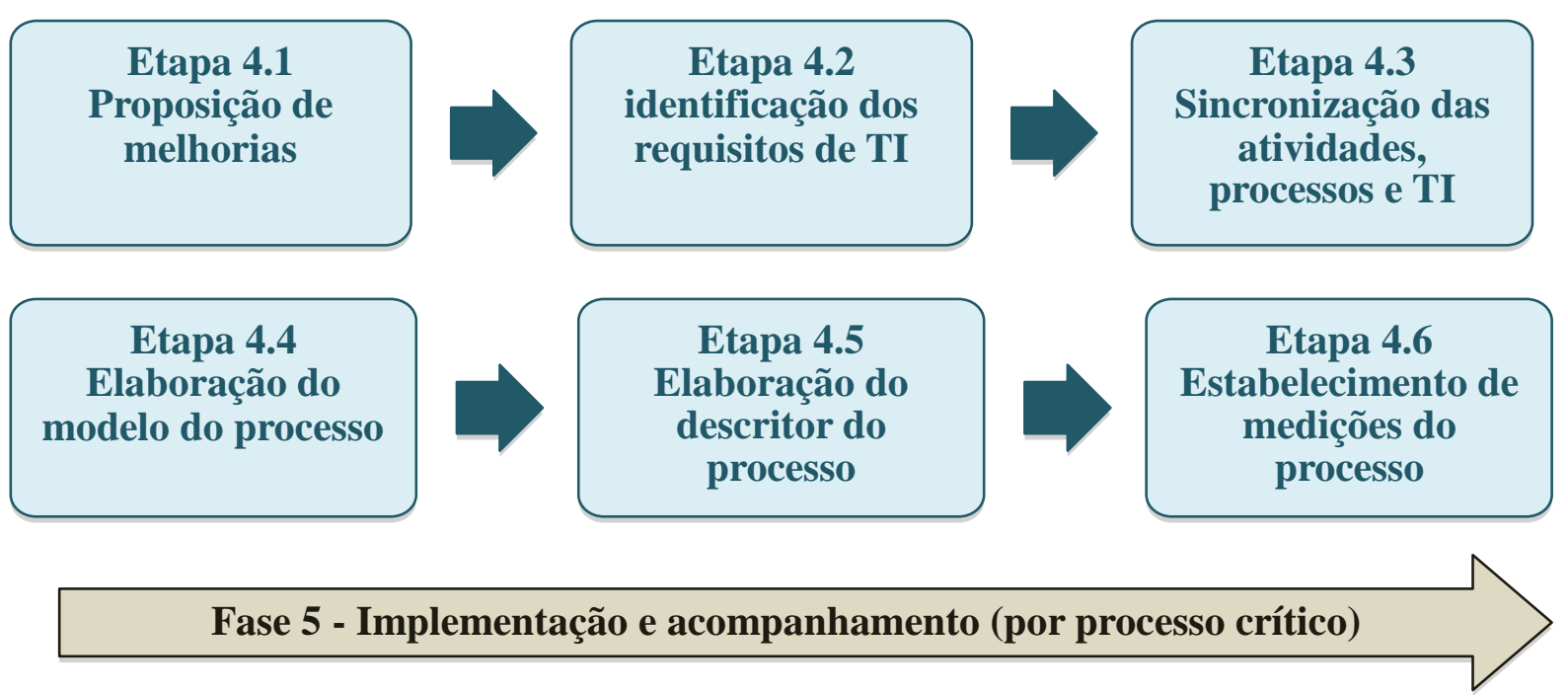

Fonte: Documento “Apresentando a Diretoria de Processos Organizacionais” elaborado pela DPR/DPO

A Etapa 4.1 corresponde à proposição de melhorias (novos sistemas, adequação dos sistemas atuais a automação de atividades, mudanças na estrutura organizacional, mudanças relacionadas aos postos de trabalho) para a correção das rupturas do processo atual. Nessa etapa, são estabelecidas metas a serem alcançadas e os responsáveis pelo processo. Na Etapa 4.2, são definidos os requisitos de tecnologia de informaçãonecessários para a modelagem dos dados.

Na Etapa 4.3, são estabelecidas estratégias para que haja integração entre atividades, processos e tecnologia de informação. A elaboração do modelo do processo (Etapa 4.4) e do descritor (Etapa 4.5) possuem o mesmo formato e padrões utilizados no mapeamento do processo atual, porém as rupturas identificadas anteriormente devem estar corrigidas; caso contrário, o fluxo deverá ser revisto. Na Etapa 4.6, encontra-se o estabelecimento do sistema de medições do novo processo, com indicadores de desempenho pré-estabelecidos, garantindo a continuidade na integração entre pessoas, processos e estratégias, conforme constatado no relato do entrevistado $\mathrm{E}_{4}$ “(...) Pelo conhecimento do fluxo atual, determinar indicadores e acompanhar os melhoramentos de processos...”. 
O resultado dessas etapas pôde ser constatado nas verbalizações dos entrevistados: $E_{2}$ “(...) depois que a gente faz o descritor a gente preenche um formulário de melhorias, oportunidades de melhorias, e são eles (unidade organizacional) que propõe. (...) a partir desse formulário a gente faz o fluxo tobe, já com tudo o que eles disseram (...) a gente vai e valida com ele esses fluxos. E, a partir disso, a gente faz um documento único, dependendo das coordenações que estão sendo mapeadas ou estudadas..."; $\mathrm{E}_{3}(. .$.$) e a gente tem também já$ formulários que são relacionados ao levantamento de melhorias e para o redesenho do fluxo já com melhoria...”; $E_{5}$ “(...) terminando com ações de melhoria, proposições e ações de melhoria"; $E_{7}$ "E agora eu já estou na parte de melhoria (...) ela já tendo essa primeira relação de todas as atividades e produtos que a coordenação tem...”.

Na quinta e última fase, as mudanças projetadas são implementadas e acompanhadas, conforme descrição das etapas na Figura 13.

Figura 13: Implementação e Acompanhamento

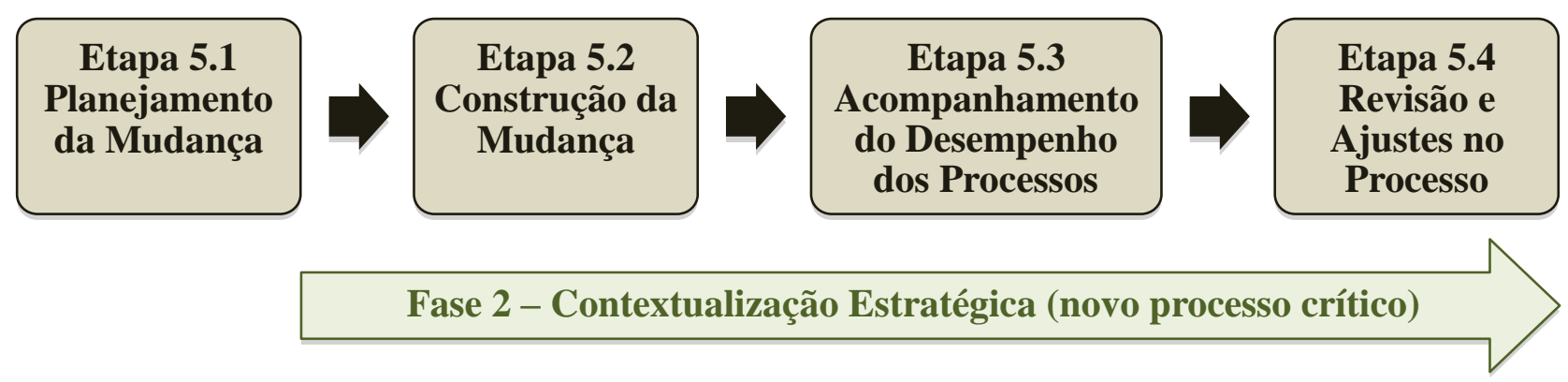

Fonte: Documento “Apresentando a Diretoria de Processos Organizacionais" elaborado pela DPR/DPO

No planejamento da mudança são definidas: estratégia; cronograma de implantação e designação de responsáveis pelo novo processo. Para a construção dessa mudança, são previstas oficinas com as equipes (DPR e unidades), em que serão definidos atitudes e papéis de cada envolvido na mudança. O acompanhamento e medição das atividades do processo serão realizados pela DPR somente quando solicitados pela unidade responsável pelo processo, caso contrário a própria unidade fará esse acompanhamento e medição, o que também ocorre na etapa de revisão e ajuste no processo, conforme relato do entrevistado $\mathrm{E}_{2}$ “(...) a partir daí é com eles (...) e se precisarem do nosso apoio (...) a gente vai estar presente...”. Terminada a Fase 5, inicia-se a contextualização estratégica de um novo processo crítico identificado pela alta administração da $\mathrm{UnB}$, seguida de todas as fases e etapas descritas anteriormente.

Em julho de 2015, com a aposentadoria da servidora que ocupava o cargo de diretora da DPR, um novo servidor assumiu a responsabilidade pela implementação da gestão por 
processos da Universidade. Por meio das últimas entrevistas realizadas em agosto de 2015, constatou-se que as fases de mapeamento, redesenho, implementação e acompanhamento dos processos identificados como críticos, estão sendo revistas e readaptadas para melhor atender às demandas das unidades da Instituição, segundo as verbalizações dos entrevistados: $E_{3}$ “(...) É uma metodologia que já está assim, acredito que só precisa se refinar o que já tem, melhorar o que já tem. Mas a gente já está trabalhando com essa metodologia...”;E9: “a gente entrou em uma segunda etapa, agora, que é uma etapa de melhoria na própria metodologia (...) a gente percebeu nessa primeira fase, que eu julgo como primeira fase, muitas vezes o cliente não queria toda aquela metodologia completa. Então, a gente fez uma alteração em que, de certa forma, oferece um menu de serviços (...) a gente procura saber o que o cliente está querendo e, a partir daí, oferece de acordo com as necessidades, pode ser a metodologia completa...”; $\mathrm{E}_{10}$ :"A metodologia é bastante densa e foi sugerida uma simplificação em um primeiro momento para que fosse permitida uma melhor absorção do conhecimento pelos usuários e redução da resistência...".

Sendo assim, infere-se que a DPR está empenhada na disseminação da visão por processos e implementação, porém é possível verificar que a etapa de acompanhamento do desempenho do processo, inserida na Fase 5, não está sendo executada pela Diretoria, ficando a cargo da area mapeada, o que pode ocasionar no abandono ou mau funcionamento do fluxo do processo.

A metodologia de implementação da gestão por processos da UnB, apesar de estar passando por ajustes, é bem estruturada e completa, auxiliando os gestores da Universidade e todos os demais envolvidos a entender seus processos, documentá-los, identificar os problemas e sugerir melhorias para sua otimização. Ademais, segundo Albuquerque e Rocha (2006), permite o sincronismo e análise da estrutura da Instituição. Observa-se que, apesar da DPR atuar como um escritório de processos, não possui autonomia para identificar quais os processos críticos que devem ser mapeados e modelados. Sua atuação depende das demandas das unidades e da identificação dos processos considerados críticos pela alta administração da Universidade. Por estar diretamente relacionado à metodologia, o detalhamento desses processos é relevante para esta pesquisa, sendo considerado a seguir.

\subsection{PROCESSOS CRÍTICOS}

Por processos críticos entende-se que são aqueles que impactam diretamente na prestação dos serviços e satisfação dos clientes (internos e externos) da UnB, impedindo ou 
dificultando o alcance dos objetivos estratégicos da Instituição. Os Relatórios de Gestão do período de 2011 a 2014 (Doc4, 2012; Doc5, 2013; Doc6, 2014; Doc7, 2015) não fazem referência à identificação dos processos críticos nos anos correspondentes. Os Relatórios de Gestão 2011 e 2012 (Doc4, 2012; Doc5, 2013), estipulam que, para o alcance do objetivo estratégico da Universidade em ter excelência e transparência na comunicação institucional em ações de gestão por processos, dentre as metas traçadas encontra-se a documentação dos processos organizacionais críticos até 2015.

No Relatório de Gestão 2013 (Doc6, 2014) encontra-se a informação de que, nesse ano, foram iniciados o mapeamento (As Is) dos processos organizacionais do Centro de Documentação da UnB (CEDOC), do Decanato de Extensão (DEX) e do Decanato de Planejamento e Orçamento (DPO). Segundo Albuquerque e Rocha (2006), o mapeamento (As Is) corresponde a análise do processo atual (As Is) que é o diagnóstico e levantamento da situação atual do processo. Dessa forma, infere-se que foram elaborados os mapas e descritores da situação atual dos processos críticos dessas unidades, porém o Relatório não descreve quais são, se foram redesenhados, implementados e acompanhados. Complementando as informações do Relatório, tem-se o Boletim Informativo DPR/2013 (Doc8, 2014), retratando o mapeamento dos processos do Decanato de Planejamento e Orçamento (DPO), mais especificamente da Diretoria de Avaliação e Informações Gerenciais (DAI), da Diretoria de Planejamento (DPL) e dos processos de apoio da Secretaria.

O Relatório de Gestão 2014 (Doc7, 2015, p.41) afirma que "apesar de conhecer os processos críticos, os gestores encontram dificuldades para solucioná-los". Além disso, relata que, apesar da gestão por processos não ser o enfoque direcionador da Instituição, algumas iniciativas de modelagem de alguns macroprocessos de apoio foram levadas a efeito. Porém, não há identificação de quais são esses processos críticos e em qual unidade foram localizados, fazendo com que o propósito estratégico de transparência nas informações para adoção da gestão por processos pela Instituição seja prejudicado.

Analisando os demais documentos, foi possível a identificação desses processos críticos no Boletim Informativo DPR/2014 (Doc9, 2015), por se tratar de um documento específico da DPR. Portanto, os processos mapeados e modelados foram: os organizacionais do Arquivo Central (ACE) da UnB relacionados aos documentos de arquivo; e o processo de elaboração e execução do orçamento do Decanato de Administração e Finanças (DAF). Corroborando com essas informações, encontra-se as seguintes verbalizações dos entrevistados: $\mathrm{E}_{2}$ : “(...) teve a divisão do DAF, do DPO, que era tudo DAF, aí foi para o DPO que tem essas questões estratégicas e financeiras. Eu acho que foi uma coisa bem necessária, 
assim, o trabalho da DPR...”; $E_{3}:$ “(...) o que a gente trabalhou até agora, acho que o mais crítico foi o processo de execução das despesas da Universidade, como os centros de custo devem executar despesas. Esse foi o mais crítico. (...) mapeamento de execução de despesas, acho que foi o mais crítico. Porque tem um impacto nos centros de custo da universidade, então todas as unidades tem interesse em saber como é, como que se realiza esse fluxo...”; E9: "A gente não mapeou toda a Universidade, (...) mas teve a cartilha (DAF/DPO) que mostrou os problemas (...) está sendo feito agora do ACE, Arquivo Central...”.

Essa Cartilha de Execução da Despesa pelos Centros de Custo da FUB, elaborada em parceria pelos Decanatos de Planejamento e Orçamento (DPO) e Administração (DAF), foi formulada após identificar como crítico o processo de elaboração e execução do orçamento do Decanato de Administração e Finanças (DAF). Esse processo foi mapeado, redesenhado e implementado pela DPR. Dessa forma, foi possível a padronização dos procedimentos administrativos, demonstrando aos Centros de Custo como devem proceder na Execução da Despesa na FUB.

Diante dessas informações constatadas em relação aos processos críticos identificados e as disponibilizadas no site da UnB, no link de mapeamento de processos, desde 2013 até outubro de 2015, foram mapeados e modelados 23 processos críticos identificados nas áreas estratégicas que compõem os macroprocessos de apoio, conforme o Quadro 5.

Quadro 5: Processos críticos identificados na UnB

\begin{tabular}{|c|c|c|}
\hline Macroprocessos de Apoio & Área & Processos \\
\hline GestãoAcadêmica & Ensino de Graduação & - Matrícula de graduação \\
\hline \multirow{4}{*}{$\begin{array}{l}\text { GestãoEstratégica e } \\
\text { Orçamentária }\end{array}$} & ApoioAdministrativo & $\begin{array}{l}\text { - Gerenciar concessões de passagens e diárias } \\
\text { - Gerenciarfrequências } \\
\text { - Planejarcompras } \\
\text { - Realizarinventário patrimonial } \\
\text { - Receber e tramitar documentos na Secretaria } \\
\text { do DPO } \\
\text { - Solicitarfornecimento } \\
\text { - Solicitarserviço }\end{array}$ \\
\hline & PlanejamentoEstratégico & $\begin{array}{l}\text { - Elaboração do Relatório de Gestão } \\
\text { - Auditoria Externa CGU }\end{array}$ \\
\hline & PlanejamentoOrçamentário & - Elaboração do Orçamento \\
\hline & $\begin{array}{l}\text { AvaliaçãoInstitucional e } \\
\text { InformaçõesGerenciais }\end{array}$ & $\begin{array}{l}\text { - Elaboração do Relatório de Autoavaliação } \\
\text { Institucional } \\
\text { - Elaboração do Sumário Executivo do } \\
\text { Relatório de Autoavaliação Institucional } \\
\text { - Recebimento de Comissões de Avaliação } \\
\text { Externa } \\
\text { - Elaboração de Artigos para Eventos } \\
\text { Relacionados a Autoavaliação Institucional } \\
\text { - Cálculo de Indicadores do TCU }\end{array}$ \\
\hline
\end{tabular}




\begin{tabular}{|c|c|l|}
\hline & & $\begin{array}{l}\bullet \text { Cálculo da Matriz de Partição Interna } \\
\text { - Disponibilização de InformaçóesEstatísticas } \\
\text { - Criar/Atualizar Site do DPO }\end{array}$ \\
\cline { 2 - 3 } & DesenvolvimentoOrganizacional & $\begin{array}{l}\text { - Modelagem de Processos } \\
\text { Apoio na Elaboração de Regimentos } \\
\text { Internos }\end{array}$ \\
\hline $\begin{array}{c}\text { GestãoFinanceira e } \\
\text { Contábil }\end{array}$ & Apoio a ProjetosAcadêmicos & $\bullet$ Gestão de ProjetosAcadêmicos \\
\hline $\begin{array}{c}\text { Gestão da Informação, } \\
\text { Comunicação e Tecnologia }\end{array}$ & Gestão de Documentos de \\
Arquivo & $\bullet$ Gênese Documental \\
\hline
\end{tabular}

Fonte: Elaborado pelo autor.

Observa-se que não há informação relativa à identificação e mapeamento de processos críticos relacionados aos macroprocessos finalísticos, porém, esses são impactados diretamente pelos processos críticos que compõem os macroprocessos de apoio.

Por exemplo, o mapeamento e redesenho do processo crítico de matrícula de graduação, que está inserido no macroprocesso de apoio de gestão acadêmica, soluciona os problemas ocorridos na tentativa dos alunos ao realizar as matrículas, e impacta no macroprocesso finalístico de ensino, pois sua resolução possibilitou melhoria na prestação de um dos serviços oferecidos pela Instituição aos seus clientes, que, nesse caso, são representados particularmente pelos alunos.

Atualmente, a DPR está realizando o mapeamento dos processos críticos da Diretoria de Acompanhamento e Integração Acadêmica (DAIA), que faz parte da estrutura organizacional do Decanato de Ensino de Graduação (DEG).

Por estar em andamento, esses e outros processos foram relatados apenas nas verbalizações dos entrevistados: $E_{6}$ : “A grande falha, a parte mais crítica é a comunicação externa, tanto com órgãos externos, como internos da UnB. (...) os processos (...), alguns deles, dependem de outras unidades acadêmicas ou de órgãos externos do Governo Federal"; $E_{7}$ : “(...) Teve o PET que é o Programa de Educação Tutorial, ele é mais complexo. (...) porque ele é longo, assim, tem vários detalhes, várias etapas..."; $\mathrm{E}_{8}$ : "Na CDAP a gente identificou algumas coisas (...) algumas questões de trabalho mesmo. Então, um das ideias que a gente propôs lá, uma melhoria, foram os formulários eletrônicos, que tange, especificamente, no termo de compromisso de estágio...”; E9: “(...) está havendo um mapeamento a respeito disso aqui no DEG...".

Dessa forma, o processo de apoio relacionado à comunicação interna e externa, o Programa de Educação Tutorial (PET) e o processo de preenchimento do termo de compromisso de estágio dos alunos, apesar não constarem no Quadro 5 por estarem em processo de mapeamento, foram identificados como processos críticos na UnB, conforme apresentado anteriormente. 
Albuquerque e Rocha (2006, p.71) afirmam que os processos críticos da organização são os "que mais influenciam no conjunto das diretrizes estratégicas, e seu redesenho tem como objetivo torná-los competitivos perante os concorrentes". Diante disso, é possível afirmar que os processos críticos identificados na UnB, entre os anos de 2011 a 2015, possuem relação direta com o desempenho da Instituição na prestação de serviços de qualidade, satisfatórios aos seus clientes (internos e externos) e que atendam às suas expectativas.

\subsection{VANTAGENS NA ADOÇÃO DA GESTÃO POR PROCESSOS}

As informações a seguir dizem respeito ao que consta no Apêndice D, de modo que uma gama de vantagens e benefícios são encontradas quando da adoção da gestão por processos pelas instituições públicas como: integração entre as unidades organizacionais; alinhamento entre tecnologia da informação e processos; prestação de serviço de melhor qualidade, que satisfaça às exigências dos clientes; melhoria contínua dos processos e dos serviços; e transparência das informações. Além da organização, os clientes (interno e externo), a alta administração, os servidores e a comunidade também são beneficiados com esse novo modelo de gestão. Os principais serviços da UnB consistem na oferta de ensino, pesquisa e extensão à sociedade, tendo como clientes internos: alunos; professores; e servidores técnico-administrativos; e externos: sociedade, instituições e órgãos de fomento.

Com base na análise dos documentos, foi possível identificar em apenas um documento - Plano de Desenvolvimento Institucional 2014-2017 (Doc1) - a relação entre a adoção da gestão por processo e suas vantagens. Segundo esse relatório (Doc1, 2014, p,36) “a gestão por processos poderá melhorar substancialmente a eficiência, a eficácia e a efetividade da administração, reduzindo a burocracia e economizando recursos". Pode-se inferir, que as

verbalizações do E2: “(...) É se pensar e tentar fazer as coisas com menos desperdício, com menos burocracia, com mais celeridade. (...) é economia mesmo de tempo, de recursos e melhorias pensadas, melhorias eficientes...”; E6: “(...) Tentar um atendimento mais rápido para o público (...) é tentar atender mais rápido, uma coisa mais eficiente”; E8: (...) vai prestar o melhor serviço para a comunidade universitária, até mesmo para quem é de fora (...)diagnosticar a situação atual e, depois, em uma situação futura a gente vai poder fazer um diagnóstico mais interessante do que a comunidade acadêmica necessita e do que esses futuros profissionais vão precisar no mercado de trabalho”; E9: “(...) buscar uma melhoria na qualidade do gasto público (...) melhoria na qualidade do serviço que é prestado...”, 
corroboram com a previsão do relatório, bem como Laurindo e Rotandaro(2006), Biazzi, Muscat e Biazzi(2011), Baldam, Valle e Rozenfeld (2014), Filho (2011), Cruz(2012), Dixon(2012),Gonçalves(2000),Hammer (2004), Manual BpmCbok (2013),e Jesus e Macieira (2014).

A gestão por processos surgiu da necessidade de se adotar um novo modelo de gestão que proporcione à UnB ter uma gestão mais flexível e eficiente, gerando um serviço de melhor qualidade no atendimento às necessidades do cidadão. Dessa forma, observa-se que o termo 'poderá melhorar substancialmente a eficiência, a eficácia e a efetividade da administração' acarreta em vários outros benefícios para a Instituição e seus envolvidos, pois é necessário analisar os desdobramentos desses termos e o que essa Instituição entende por isso. Diz-se que uma organização é eficiente quando atinge o resultado com o mínimo de perda de recursos durante o processo, fazendo melhor uso de dinheiro, mão-de-obra e material; é eficaz quando é objetiva e alcança seu planejamento inicial, sem se importar com os meios; e efetiva quando é capaz de produzir efeito. Portanto, quando se diz que a UnB possui uma gestão eficiente infere-se que essa tem por vantagem proporcionar serviços de qualidade, que correspondam aos anseios dos clientes.

Há de se lembrar que para o desenvolvimento da UnB, o alinhamento entre tecnologia da informação e processos é extremamente importante e vantajoso, pois sistemas integrados permitem comunicação ágil entre as areas e transparência nas informações. Resolver essa fragilidade em relação ao alinhamento é um dos benefícios da gestão por processos, conforme as verbalizações $\mathrm{E}_{1}$ : “(...) principal vantagem imediatamente seria resolver esse problema de alinhamento de TI e area de negócio em relação à sistemas corporativos...”; $E_{3}$ : “(...) A melhoria contínua é importante e até esse alinhamento entre a gestão por processos e a TI”. Para Davenport (1994), por meio dos processos é possível o alinhamento entre pessoas, estratégia e tecnologia.

Por economia de recursos, conforme consta no PDI 2014-2017 (Doc1, 2014), inferese vantagens como: eliminação de desperdícios; e redução de custos e melhoria nos processos. Para Cruz (2012), a medição de melhorias nos processos é um benefício pois facilita a gestão por processos. Para o Manual BPM CBOK (2013), essa medição possibilita a avaliação e redução dos custos. Para Baldam, Valle e Rozenfeld (2014), com a adoção dessa gestão temse a vantagem da eliminação de redundâncias e atividades duplicadas, permitindo limitar os desperdícios e prevenir a ocorrência de erros, melhorando o uso de recursos disponíveis. Esses benefícios são evidenciados em algumas verbalizações $E_{2}$ : “(...) É se pensar e tentar 
fazer as coisas com menos desperdício...”; $\mathrm{E}_{3}$ :“(...) percebe fragilidades, pontos de melhoria...”; $\mathrm{E}_{9}$ : “(...) buscar uma melhoria na qualidade do gasto público...”.

O entendimento do fluxo dos processos, transparência das informações e a integração entre as unidades são vantagens destacadas em várias verbalizações, como $E_{3}$ : “(...) conhecer o que faz. A universidade não conhece o que faz. (...) Do próprio conhecimento dos fluxos do processo e dessa maior integração entre as áreas e de introdução de pequenas melhorias (...) Possibilita transparência mesmo dos processos, não só para a comunidade interna mas, também, para a externa." $\mathrm{E}_{4}$ : (...) Do próprio conhecimento dos fluxos do processo e dessa maior integração entre as áreas (...) clareza dos processos para maior organicidade e da publicização"; E 5 : “(...) demonstrar para os servidores todo o fluxo de processo, de maneira simples e clara, ajudando na horizontalização...”; $\mathrm{E}_{7}$ : “(...) todo mundo sabendo de como funciona...”; $\mathrm{E}_{10}$ : “(...) conhecimento de como a universidade funciona, independente de quem forem os gestores e, com isto, executar os processos sempre em conformidade com as exigências legais"; e ratificadas na visão de Baldam, Valle e Rozenfeld (2014), Filho(2011), Cruz (2012), Manual BPM CBOK (2013), De Sordi (2012), e Paim et al. (2009).

Para esses autores, esses benefícios permitem uma visão integrada da organização, coordenando e integrando o trabalho entre as areas funcionais, estabelecendo responsabilidades, identificando subsídios necessários aos processos e transparência na prestação de informações. A integração entre as areas é de fundamental importância para que os processos estejam alinhados em prol da efetividade organizacional e na busca da vantagem competitiva para, assim, sobreviver nesse ambiente de mudanças e transformações.

Jesus e Macieira (2014) apresentam os propósitos de uma organização em adotar a gestão por processos que são extremamente semelhantes às vantagens apontadas. Subentendese que a partir do momento em que o propósito é alcançado, passa a ser considerado um benefício obtido. Por exemplo, a partir do momento que a UnB tem como propósito a condução de tecnologia de informação integrada à processos e consegue atingir um resultado positivo, apresentará vários outros benefícios como: alinhamento entre a tecnologia de informação e processos; unidades organizacionais integradas, transparência das informações etc. Um propósito ou uma vantagem podem originar em vários outros.

Todos esses benefícios apontados permitem uma mudança na forma de agir e pensar a gestão por processos e sua adoção, possibilitando uma melhor compreensão da Instituição e das melhorias necessárias para a sobrevivência. É necessário que os envolvidos tenham conhecimento dessas vantagens, de forma que visualizem a importância da gestão por 
processos e as melhorias internas e externas, por essa proporcionadas, que são capazes de mudar positivamente a forma de gestão da Instituição.

A Universidade de Brasília necessita de uma ampla divulgação em relação aos benefícios e vantagens na adoção da gestão por processos, tanto que, em todo material analisado, não foi evidenciado se houve algum benefício com essa adoção ou quais são as possíveis vantagens.

Os documentos da Universidade, bem como as entrevistas, retratam as falhas, oportunidades, objetivos estratégicos, pontos fortes e fracos, porém não há relatos associando o impacto que a gestão por processos poderá causar nessas deficiências. Os envolvidos na Instituição precisam deter esse conhecimento para que essa adoção tenha o apoio de todos e alcance os resultados almejados.

\subsection{DIFICULTADORES PARA IMPLANTAÇÃO DA GESTÃO POR PROCESSOS}

A respeito dessa categoria de análise, as informações a seguir levam em conta o que consta no Apêndice E. Como em todo modelo novo, algumas barreiras são identificadas para a implantação da gestão por processos nas organizações, como: cultura organizacional; falta da disseminação da visão por processos; resistência à mudança; falta de apoio da alta administração; falta de comprometimento dos funcionários; infraestrutura precária; falta de capacitação para os funcionários etc. Esses fatores dificultadores, quando são executados de maneira correta, passam a ser denominados de fatores críticos de sucesso, que são necessários para contribuir de modo decisivo na implantação bem sucedida dessa gestão.

Os pontos fracos da UnB, e que se enquadram como dificultadores para a implantação da gestão por processos, são identificados no PDI 2014-2017 (Doc1, 2014), Relatório de Gestão 2012 (Doc5, 2013), Relatório de Gestão 2013 (Doc6, 2014) e Relatório de Gestão 2014 (Doc7, 2015). Fazendo uma síntese das informações contidas nesses relatórios, infere-se que os fatores dificultadores encontrados na UnB são: falta de plano de comunicação institucional; ausência de padronização na comunicação das unidades com o público; inadequação qualitativa e quantitativa da infraestrutura física e tecnológica para o novo contexto sociocultural; espaço físico e infraestrutura inadequados; ineficiência dos processos administrativos e organizacionais; alta rotatividade de servidores, em função de capacitação insuficiente e precárias condições de trabalho; falta de coesão interna e visão institucional; resistência a mudanças e ao funcionamento impessoal; e fragilidade de governança. 
Corroborando com esses Relatórios, o fator dificultador relacionado à infraestrutura pode ser identificado na verbalização $E_{1}$ : “(...) tem esse problema, também, que eu acho, por exemplo, parte da infraestrutura (...) esse é um fator limitante porque nós vamos precisar aumentar a equipe (...) nossa sala agora é tão limitada que se a gente quiser contratar mais uma pessoa a gente não consegue colocar mesa, esse é um fator limitante porque nós vamos precisar aumentar a equipe...”. Para Jesus e Macieira (2014); Baldam, Valle e Rozenfeld (2014), Tregear, Jesus e Macieira (2010) e Paim et al. (2009), uma maneira de se pensar na organização por meio da gestão por processos está na criação de um Escritório de Processos com recursos, equipe e a infraestrutura necessárias para a promoção da governança dos processos. Sem uma estrutura adequada, não há como garantir as práticas de gerenciamento por processos.

As verbalizações a seguir, demonstram o consenso, entre oito dos 10 entrevistados, em relação aos fatores dificultadores: resistência à mudança e cultura organizacional. Fatores, esses, que também foram identificados nos Relatórios como pontos fracos. $\mathbf{E}_{1}$ : “(...) a outra dificuldade, a gente vencer a cultura muito consolidada. (...) o fato de não existir, até mesmo pela UnB não ter esse modelo, ela tem problemas característicos de toda instituição que não tem esse modelo. (...) a gente encontra dificuldade para as pessoas aceitarem esse modelo. (...) a gente sabe que gestão por processos é um modo de se ver que, de certa forma, faz com que as pessoas se sintam em risco em relação ao poder de informação, ela tem que de repente, abrir o leque das informações, porque tem pessoas que tem resistência a isso, tem pessoas que tem resistência à mudança, qualquer mudança que seja (...). Porque o processo ele põe às claras do que é feito, qualquer organização tem sempre aquele receio. É problema de cultura, tudo está relacionado à cultura...”; $\mathbf{E}_{2}$ : “(...) eu acho que, principalmente, a resistência (...) Outra coisa, que até pelas pessoas não entenderem a cultura por processos e a resistência à mudanças, isso atrapalha muito nosso trabalho. (...) É a resistência mesmo, de não entenderem para que aquilo funciona, e de não entenderem que o trabalho é demorado. (...) Acho que é isso, resistência e dificuldade deles de participarem de tantas reuniões."; $\mathbf{E}_{\mathbf{3}}$ : "São muitas. A questão da sensibilização das pessoas (...). Tem essa dificuldade de você conseguir sensibilizar mesmo as pessoas a participar das reuniões, irem até o fim para a gente ter o fluxo finalizado (...) a dificuldade maior é em conseguir mudar essa cultura da universidade...”; $\mathbf{E}_{\mathbf{4}}$ : "Resistência, de um modo geral, pelo fato da gestão por processos clarear e trazer à tona os problemas que estão envolvidos nos processos, problemas de execução. Resistência por parte dos funcionários, também, que às vezes querem reter conhecimento, questão de poder (...). Também há resistência por ser um trabalho colaborativo...”; $\mathbf{E}_{\mathbf{5}}$ : “(...) adaptar os servidores a 
um novo tipo de serviço e mudança na maneira de trabalhar dos servidores. Que toda mudança gera um desconforto.”; $\mathbf{E}_{7}$ : “(...) a maioria (servidores) tem preguiça, não quer vim para as reuniões, tem gente nossa aqui que acha uma bobagem (...). Resistência por parte dos servidores, uns porque não tem tempo também, trabalham demais e não tem como vim, outros porque não querem, porque vão ter que trabalhar...”; $\mathbf{E}_{\mathbf{9}}$ : “(...) primeiro, uma das coisas que a gente acha que é importante, é evidenciação desses processos mapeados, então, esses processos estão sendo jogados na internet para ficar claro, mas algumas pessoas não gostam que isso se torne claro (...) permite que as pessoas notem as nossas ineficiências que não são corrigidas. O segundo aspecto são dificuldades de pessoas, questão pessoal mesmo..."; $\mathbf{E}_{\mathbf{1 0}}$ : “(...) Resistência à mudança gerada por uma cultura do 'carimbo', como se diz, fazendo com que a otimização seja relegada a um segundo plano...”.

Carbone (2000); Junquilho (2004); Albuquerque e Rocha (2006) reafirmam que a cultura organizacional das instituições públicas brasileiras é responsável por ações que influenciam negativamente o desenvolvimento do novo modelo de gerenciamento por processos em oposição ao tradicional gerenciamento funcional. Assim como Filho (2011, p.18), que especifica como fator impeditivo "a carência de uma cultura automatizada na organização para alterar e simplificar processos". Pode-se afirmar que a resistência à mudança encontrada na UnB está ligada a cultura da organização que, segundo Junquilho (2004), é reflexo das práticas cotidianas construídas a partir de um processo histórico-social.

Vieira e Vieira (2004) apontam três razões para a resistência encontrada nas universidades públicas: o medo à mudança; os interesses pessoais; e a proteção corporativa. $\mathrm{O}$ que geralmente se identifica nessas Universidades, e que também pode ser constatado na UnB,são servidores que possuem muitos anos de carreira, se sentem 'donos' das informações relacionadas aos serviços e não tem interesse em mudar a forma de trabalhar, dificultando, assim, a gestão da mudança para uma organização orientada por processos. Muitos não querem repassar as informações de como as atividades são executadas, por medo de perder o domínio do serviço ou medo de tornar pública suas ineficiências, além de alegarem 'falta de tempo’ para assumir novos compromissos.

A falta de capacitação foi citada por dois entrevistados: $E_{2}$ : “(...) eu acho que, principalmente, a resistência e a falta de conhecimento e capacitação na area...”; $\mathrm{E}_{10}$ : “(...) capacitação nas duas metodologias - uma para implementação da visão e gestão por processos, que está associada à gestão e administração da empresa - e outra técnica para desenho dos processos, a qual utiliza uma ferramenta...”; e apontada, nos Relatórios, como causa pela rotatividade de pessoal na Universidade. Albuquerque e Rocha (2006) ratificam, 
em todos os passos da metodologia apresentada, para a implantação da gestão por processos nas organizações, a importância dos programas de capacitação para os servidores, além disso, essa capacitação é considerada por Baldam, Valle e Rozenfeld (2014); Ramos (2011); Almeida (2002), como um dos fatores críticos de sucesso.

Segundo o Guia BPM CBOK V3.0 (2013), a capacitação dos servidores que trabalham diretamente com o gerenciamento por processos é importante pois esses devem ser especializados em abordagens, conceitos, métodos, técnicas e ferramentas relacionados a esse gerenciamento, de forma que possam atuar como consultores internos em iniciativas de transformação. Sem a devida capacitação dos servidores, não é possível promover a governança dos processos, disseminar culturalmente esse modelo de gestão, promover a modelagem dos processos e sua gestão no dia-a-dia. $\mathrm{Na} U \mathrm{UnB}$, conforme o entrevistado $\mathrm{E}_{1}$ afirmou, a Diretora da DPR, além de incentivar os estudos na area de gestão por processos, organizou uma biblioteca para capacitação dos servidores que estão lotados na diretoria e alguns eventos (workshop, seminários etc.). Porém, não há investimento em uma capacitação formal, um curso intensivo de formação de gestores que possam atuar e disseminar esse modelo de gestão, com certificação da ABPMP Brasil, que é uma associação internacional dedicada às práticas e promoção dos conceitos de gerenciamento por processos e formação de profissionais.

A falta de conhecimento do que significa gestão por processos pelos envolvidos na UnB é uma barreira para implantação, tendo em vista que, para Jesus e Macieira (2014), essa gestão tem como propósito: dar conhecimento à todos os envolvidos sobre quais são os principais processos, suas interações e como esses afetam as relações internas e externas; sendo assim, sem o devido entendimento e reconhecimento da importância de processos por todos, não há como se pensar nessa gestão, muito menos na sua implantação. Esse dificultador foi constatado nas verbalizações - $E_{2}$ : “(...) eu acho que, (...) a falta de conhecimento (...) até pelas pessoas não entenderem a cultura por processos...” $E_{7}$ : Não tem divulgação, ninguém sabe o que é mapeamento, para que serve (...); $E_{9}$ : “(..) há uma incompreensão do que significa gestão por processos, alguns acham que pode resolver, é um milagre, outros acham que não é necessário (...) mas é muito complicado, na Universidade, porque, muitas vezes, a gente tem que lidar com o imediato (...) gestão de processos é uma coisa muito de médio a longo..."; - e nos pontos fracos relacionados à falha na comunicação; e falta de coesão interna e visão institucional.

O apoio da alta administração é um fator importante para a adoção da gestão por processos, porém quando não é possível identificar esse apoio na Instituição, se torna um 
dificultador, o que se pode inferir das verbalizações dos entrevistados: $E_{3}$ : “(...) acho que, talvez, um envolvimento da alta gestão, mais ativo, seja muito importante..."; E8: "Falta um pouco de apoio das pessoas..."; é que na UnB falta um envolvimento e apoio mais ativo da alta administração e dos demais servidores. Laurindo e Rotandaro (2015) e Baldam, Valle e Rozenfeld (2014) evidenciam que esse apoio é um fator crítico de sucesso para a evolução da organização, principalmente para a institucionalização dessa forma de gestão. Se esse modelo de gestão não é reconhecido e sem o apoio necessário daqueles que são responsáveis pela organização, não é possível esperar o comprometimento dos envolvidos na organização.

A falta de metodologia adequada, ficando os processos a cargo de experimentos descontinuados, é considerado empecilho para a implantação da gestão por processos, segundo Baldam, Valle e Rozenfeld (2014), Ramos (2011) e Vaz (2008); corroborando com essa visão, encontra-se a verbalização do $E_{9}$ : “(...) a gente sofre um pouco de algumas nossas limitações. Primeiramente, a metodologia, ela estava muito engessada, a gente conseguiu abrir um pouco (...) naturalmente isso tem problemas, pode gerar problemas, porque a gente não pega a melhor metodologia, mas é um risco meio calculado de relação custo-benefício..."; e a ineficiência dos processos administrativos e organizacionais, ponto fraco apresentado nos Relatórios. A adoção de uma metodologia padrão para modelagem e padronização dos processos da UnB permitem a compreensão, comunicação e gerenciamento dos componentes desses, criando uma representação abstrata da realidade de maneira completa e precisa em relação ao seu funcionamento.

Infere-se que, para se obter êxito na implantação da gestão por processos na UnB, deve-se pensar em medidas eficientes que tenham como foco apresentar soluções para os pontos fracos, recorrentes, identificados nos Relatórios. Diante dos fatores críticos de sucesso apresentados por Baldam, Valle e Rozenfeld (2014), Ramos (2011) e Vaz (2008), pode-se afirmar que a Universidade possui diversos elementos sendo executados de maneira incorreta, coibindo a evolução organizacional. 


\section{CONCLUSÕES}

Este estudo de caso apresentou o processo de evolução da Universidade de Brasília em termos de uma instituição orientada por processos, como consequência da necessidade em se adotar um modelo de gestão eficiente. A importância desta visão por processos proposta pela Universidade demonstra a sua preocupação na busca da efetividade em termos estratégicos, táticos e operacionais.

O modelo de gestão por processos adotado pela UnB contempla o enfoque administrativo, preocupa-se com aspectos importantes para sua implantação e manutenção, com o alinhamento estratégico e com o envolvimento da tecnologia da informação à gestão de mudança e melhoria contínua, sempre com o objetivo de atender ao cliente interno e externo com qualidade. Inserido nesse modelo encontra-se a Diretoria de Processos Organizacionais, desempenhando as funções do escritório de processos, que está como responsável pela promoção da gestão por processos e a evolução do desenho dos processos na Instituição.

Para implementação da gestão por processos, o modelo desenvolvido não foi totalmente definido ou determinado pela literatura por questões da natureza da própria Instituição, possui características próprias, respeitando às especificidades da Instituição e utilizando-se de vários modelos como base e sustentação. Esse modelo está em constante renovação e readequação, tendo em vista as mudanças estruturais e organizacionais que ocorrem na Instituição.

Para a implementação da gestão por processos, a UnB apresentou uma metodologia baseada no modelo de sincronismo organizacional. Essa não está voltada somente para o mapeamento e modelagem dos processos críticos identificados pela alta administração, mas também para o sincronismo entre os processos organizacionais e os ambientes interno e externo da Instituição. Observa-se que a gestão por processos está sendo implantada na Universidade de maneira gradual, tendo em vista que a metodologia está sendo aplicada pontualmente em processos críticos identificados nas áreas estratégicas dos macroprocessos de apoio e finalísticos.

Sendo assim, não se pode afirmar que a gestão por processos está totalmente implantada, pois, para isso, todos os processos identificados como críticos na Universidade deveriam estar mapeados, redesenhados, implementados e acompanhados. Além disso, é necessária a integração entre tecnologia da informação e os processos organizacionais, permitindo uma gestão integrada, com sistemas integrados e direcionados aos processos. 
Somando-se a isso, observa-se que a disseminação da visão por processos encontra-se concentrada na Reitoria e Decanatos, ficando grande parte da Instituição sem o devido conhecimento do que significa gestão por processos e sua aplicabilidade. Para a implantação da gestão por processos na Instituição, é de grande importância a conscientização de todos os envolvidos sobre qual papel irão desempenhar neste novo modelo organizacional, bem como o motivo pelo qual estão desempenhando uma atividade dentro de uma visão maior.

Conforme evidenciado nesta pesquisa, desde o surgimento da ideia em se adotar o modelo de gestão por processos, até a criação e aplicação da metodologia, houve evolução organizacional em termos dessa abordagem. A atenção da alta gerência em identificar os processos críticos tem demonstrado a preocupação com a efetividade na adoção da estrutura por processos na Instituição, ratificando a importância desses para o processo de aprendizagem e evolução em termos de processo.

Com base nesta pesquisa, verificou-se que a adoção da estrutura por processos não está plenamente efetivada; identificou-se a presença de características de uma organizacional funcional com processos em segundo plano, ou seja, os elementos funcionais, como a hierarquia e a departamentalização, predominantemente presentes, todavia identificou-se o reconhecimento da existência dos processos organizacionais transversais, demonstrando que o foco da visão da Instituição está mudando. Para um efetivo gerenciamento por processos na Universidade, não se pode manter uma estrutura em que o comando e controle hierárquico prevaleçam, nem que a avaliação dos processos seja feita pontualmente, pois dessa forma a Universidade não está voltada para a gestão por processos, mas para a gestão de processos.

$\mathrm{Na}$ adoção da gestão por processos pela Universidade, a DPR tem desempenhado um papel estratégico, pois além do desenvolvimento da implementação da metodologia que está sendo aplicada, busca-se um modelo de governança por processos adequado à Instituição, que permita a integração e flexibilização intraorganizacional e proposição de melhorias na gestão. Foi por meio do empenho da Diretoria que ocorreu a institucionalização da gestão por processos na UnB e reconhecimento pela alta administração que esse modelo é o adequado para uma gestão de excelência no ensino, pesquisa e extensão.

Esses resultados demonstram que a Universidade passa por uma fase de transição, caracterizando um aprendizado por todos os envolvidos e, principalmente, que as resistências apresentadas a esse novo modelo de gestão proposto estão sendo reduzidas pela internalização dos conceitos e absorção do conhecimento por parte dos servidores, sobre a metodologia proposta pela DPR. 
É fundamental para a cultura organizacional da Universidade valorizar a comunicação entre as pessoas, constância de propósitos na execução das atividades, visão de longo prazo, critérios mais flexíveis de execução das atividades, abertura a influências externas ao sistema e pontos de vista alternativos para a tomada de decisão. Caso não haja essa valorizção, a continuidade da mudança pode culminar na inviabilização do modelo de gestão por processos, denotando fragilidades no direcionamento estratégico da UnB, expondo deficiências da alta administração.

Diante dos resultados apresentados nesta pesquisa, foi possível a identificação de elementos relacionados à capacidade organizacional da Universidade, como: cultura que está sendo gradualmente modificada de uma visão funcional para a visão orientada por processos; conhecimento, pois a metodologia de implantação permite o conhecimento amplo do modelo de gestão por processos que está sendo adotado; e liderança dos membros das equipes que estão tendo seus processos mapeados e pela alta administração que os apoia integralmente.

Com a adoção da gestão por processos, a Universidade passou a apresentar vantagens na prestação dos seus serviços. A execução do fluxo dos processos se tornou transparente e de conhecimento de todos: docentes, discentes, servidores e sociedade. A cada processo mapeado e redesenhado apresenta-se melhorias que impactam na eficiência, eficácia e efetividade da administração. Ademais, foi possível identificar a integração entre as unidades organizacionais por onde esses tramitam.

Diante dos resultados, fatores dificultadores para implantação da gestão por processos nesta Instituição foram identificados, como: resistência dos servidores às mudanças; existência da cultura organizacional burocrática; infraestrutura precária para mapeamento e modelagem dos processos; falta de comprometimento e alta rotatividade dos servidores; e falta de recursos para colocar em prática o programa de capacitação elaborado pela DPR.

Cabe ressaltar que as vantagens e fatores dificultadores identificados na implantação da gestão por processos, não correspondem, em termos absolutos a todos benefícios e dificuldades na adoção desse modelo por qualquer instituição pública. Essa identificação está vinculada ao contexto particular em que se encontra a Universidade, respeitando suas especificidades e percepção dos envolvidos.

Outro aspecto relevante deste estudo é o de que a adoção da gestão por processos não se concretizará apenas pela institucionalização desse modelo, é necessário que os processos organizacionais sejam priorizados como um eixo gerencial de maior importância que o eixo funcional. Os servidores passem a trabalhar além da unidade organizacional, com foco nos processos, sendo reconhecidos pelas melhorias ofertadas na prestação dos seus serviços. 
Nesta pesquisa, foram consideradas as percepções dos participantes diretamente envolvidos com a implantação da gestão por processos, de modo que outros indivíduos poderiam ter participado da pesquisa e colaborado com suas percepções sobre o que significa processos, gestão por processos, vantagens e dificultadores na implantação.

Recomenda-se em termos de investigações futuras a respeito desse tema: estudos que vislumbrem a continuidade desta pesquisa, que possibilitem investigar as mudanças ocorridas na metodologia de implantação e os resultados dos processos críticos que estão em fase de mapeamento e redesenho; estudos comparativos entre a metodologia utilizada na Instituição para a implantação da gestão por processos com as de outras instituições públicas de ensino superior, objetivando identificar possíveis melhorias e disfunções; e estudos que demostrem se é viável ou não expandir aos demais Campi da Universidade a atuação da DPR e sua possível inserção estrutural nesses Campi, de modo a possibilitar a implantação da gestão por processos no âmbito de toda Universidade. Sugere-se, por fim, a construção de um instrumento de avaliação destinado ao acompanhamento dos processos críticos que foram mapeados e redesenhados, possibilitando, também, a identificação das vantagens para a Instituição na adoção desse modelo de gestão.

Para que a Instituição possa gerar um serviço de melhor qualidade no atendimento às necessidades do cidadão, foi necessária a restruturação da sua gestão organizacional, almejando torná-la flexível e eficiente. Este estudo fornece uma visão de como está sendo a reestruturação por processos na $\mathrm{UnB}$ e fornece subsídios para futuros ajustes e planejamento que viabilizem a participação de todos os envolvidos na Universidade, buscando a otimização de resultados, por meio do gerenciamento por processos. 


\section{REFERÊNCIAS}

AALST W.; HOFSTEDE A.; WESKE M. Business Process Management: A Survey. IN: International Conference on Business Process Management (BPM 2003), In: Business process management. Springer Berlin Heidelberg, 2003.

ALBUQUERQUE, A.; ROCHA, P. Sincronismo organizacional: como alinhar a estratégia, os processos e as pessoas. 1. ed. São Paulo: Saraiva, 2006.

ALMEIDA, L. G. Gestão do processo e a gestão estratégica. Rio de Janeiro: Qualitymar, 2002.

BALDAM, R. L.; VALLE, R. A. B.; PEREIRA, H. R. M.; HILST, S. M.; ABREU, M. P.; SOBRAL, V. S. Gerenciamento de processo de negócios: BPM - Business Process Management. 1. ed. São Paulo: Érica, 2007.

BALDAM, R.; VALLE, R.; ROZENFELD, H. Gerenciamento de processos de negócios: BPM. 4 ed. Rio de Janeiro: Elsevier, 2014.

BARDIN, L. Análise de conteúdo. Lisboa: Edições 70, 1985.

BERTALANFFY, Ludwig Von. Teoria Geral dos Sistemas. Tradução de Francisco M. Guimarães, Fundamentos, desenvolvimento e aplicações. Petrópolis: Vozes, 2008.

BIAZZI, M. R.; MUSCAT, A. R. N. Modelo de Aperfeiçoamento de Processos Administrativos para Instituições Públicas de Ensino Superior Brasileira. In: XXXI Encontro da ANPAD - ENANPAD. Anais Eletrônicos. Rio de Janeiro, RJ, 2007.

BIAZZI, M. R; MUSCAT, A. R. N.; BIAZZI, J. L. Modelo de aperfeiçoamento de processos em instituições públicas de ensino superior. Gestão \& Produção, São Paulo, v. 18, n. 4, p. 869-880, 2011.

BIAZZI, M. R. Instituições públicas de ensino superior: estudo de casos de aperfeiçoamento de processos administrativos. 2007. Dissertação (Mestrado em Engenharia de Produção) Escola Politécnica, Universidade de São Paulo, São Paulo, 2007. Disponível em: <http://www.teses.usp.br/teses/disponiveis/3/3136/tde-09082007-181330/>. Acesso em: 30 maio 2014.

BRASIL. Decreto $n^{0} 5.773$, de 7 de maio de 2006. Dispõe sobre o exercício das funções de regulação, supervisão e avaliação de instituições de educação superior e cursos superiores de graduação e seqüenciais no sistema federal de ensino. Diário Oficial da República Federativa do Brasil, Brasília, 10 maio 2006. Disponível em:

http://www.planalto.gov.br/ccivil_03/_Ato2004-2006/2006/Decreto/D5773.htm. Acesso em: 20 nov 2014.

Decreto $\mathrm{n}^{0} 5.383$, de 3 de março de 2005. Dispõe sobre a criação da câmara de políticas de gestão pública, do conselho de governo, e dá outras providências. Diário Oficial da República Federativa do Brasil, Brasília, 04 de março de 2005. Disponível em: 
http://www.planalto.gov.br/ccivil_03/_Ato2004-2006/2005/Decreto/D5383.htm. Acesso em: 20 nov 2014.

Decreto-Lei $n^{\circ} 200$, de 25 de fevereiro de 1967. Dispõe sobre a organização da Administração Federal, estabelece diretrizes para a Reforma Administrativa e dá outras providências. Diário Oficial da República Federativa do Brasil, Brasília, 27 de fevereiro de 1967. Disponível em: http://www.planalto.gov.br/ccivil_03/decreto-lei/Del0200.htm. Acesso em: 20 nov 2014.

Ministério da Administração Federal e Reforma do Estado. Programa da qualidade e participação na administração pública / Ministério da Administração Federal e Reforma do Estado: Brasília: MARE, 1997.

Ministério do Planejamento, Orçamento e Gestão. Secretaria de Gestão Pública. Programa GESPÚBLICA, Modelo de Excelência em Gestão Pública, Brasília; MP, SEGEP, 2014.

Ministério Público Federal. Secretaria Jurídica e de Documentação. Escritório de Processos Organizacionais do MPF. Manual de gestão por processos. Brasília: MPF/PGR, 73 p. 2013.

Secretaria de Estado de Planejamento e Gestão. Guia para Melhoria de Processos no Governo de Minas Gerais. Minas Gerais, 83p. 2011.

BRODBECK, A. F; MUSSE, J. I; SILVA, M. V; ZIMMERMANN, A. Implementação de escritório de processos em organizações governamentais: o caso de uma instituição de ensino superior. Workshop de Tecnologia da Informação e Comunicação das IFES do Brasil. TI sem fronteiras. João Pessoa: UFPB, 2013.

CAPOTE, G. BPM para todos: uma visão geral abrangente, objetiva e esclarecedora sobre gerenciamento de processos de negócio. 1. ed. Rio de Janeiro: Gart Capote, 2012.

CARBONE, P. P. Cultura organizacional do setor público brasileiro: desenvolvendo uma metodologia de gerenciamento da cultura. Revista de Administração Pública, v. 34, n. 2, p.133-144, 2000.

CRESWELL, J. W. Projeto de pesquisa: métodos qualitativo, quantitativo e misto (2. ed., L. de O. Rocha, Trad.). Porto Alegre: Artmed, 2007.

CRUZ, T. Sistemas, métodos e processos: administrando organizações por meio de processos de negócios. 2. ed. São Paulo: Atlas, 2012.

CUNHA, A. U. N. Mapeamento de processos organizacionais na UnB: Caso Centro de Documentação da UnB - CEDOC. 2012. 66 f. Monografia (Especialização em Gestão Universitária) - Departamento de Administração, Universidade de Brasília, Brasília-DF, 2012.

DAVENPORT, T.H. Reengenharia de Processos: Como inovar na empresa através da tecnologia da informação. Rio de Janeiro: Ed. Campus, 1994, 298p. 
DEMO, P. Metodologia científica em ciências sociais. 2.ed. São Paulo: Atlas, 1989.

DE SORDI, J. O. Gestão por processos: uma abordagem da moderna administração. 3.ed. São Paulo: Saraiva, 2012.

DIXON, J. HypeCycle for Business Process Management, 2012.

FERREIRA, A. S. R. Modelagem organizacional por processos. 1.ed. Rio de Janeiro: Mauad, 2010.

FERREIRA, V. C.; SILVEIRA, M. C.; OLIVEIRA, K. P.; MORAES, C. E. Contribuições do gerenciamento de processos para a administração pública mineira. REUNA, vol.19, n.1, p. 528, 2014.

FRANCO, M. L. P. B. Análise de conteúdo (Vol. 6). Líber Livro, 2008.

FIEL-FILHO, A. Gestão dos processos e a eficiência na Gestão Pública. In: KANAANE, R.; FIEL-FILHO, A.; FERREIRA, M.G. (orgs.). Gestão pública: planejamento, processos, sistemas de informação e pessoas. São Paulo: Atlas, 2010.

FILHO, B. F. A. Processos Organizacionais: simplificação e racionalização. São Paulo: Atlas, 2011.

FONSECA, J.J. S. Metodologia da pesquisa científica. Fortaleza: UEC, 2012.

GIL, A. L. Métodos e técnicas de pesquisa social. São Paulo: Atlas, 2008.

GONÇALVES, J. E. L. G. As empresas são grandes coleções de processos. Revista de Administração de Empresas, v.40, n.1, p.6-19, jan./mar., 2000.

Processo, que processo? Revista de Administração de Empresas, São Paulo, v. 40, n.4, p.8-19, out/dez. 2000b.

GULLEDGE, T. R.; SOMMER, R. A. Business process management: public sector implications. Business Process Management Journal, v.8, n.4, p. 364-376, 2002.

HAMMER, M. A agenda. São Paulo: Almedina, 2004.

JESUS, L.; MACIEIRA, A. Repensando a gestão por meio de processos: como BPM pode transformar negócios e gerar crescimento lucrativo. Rio de Janeiro: Algo Mais Editora, 2014.

JUNQUILHO, G. S. Nem "burocrata" nem "novo gerente": o "caboclo" e os desafios do Plano Diretor de Reforma do Estado no Brasil do real. Revista de Administração Pública, v. 38, n. 1, p. 137-156, 2004.

LAKATOS, E. M.; MARCONI, M. D. A. Fundamentos de pesquisa metodológica científica. São Paulo: Atlas, 2003. 
LAURINDO, F. J. B.; ROTONDARO, R. G. Unindo tecnologia da informação e gestão por processos: introdução e objetivos. In: . (Coord.). Gestão integrada de processos e da tecnologia da informação. São Paulo: Atlas, 2006, p. 1-13.

LIMA, P. D. B. Execelência em gestão pública: a trajetória e a estratégia do gespública. Rio de Janeiro :Qualitymark Editora, 2013. 2a impressão.

MANZINI, E. J. Entrevista semi-estruturada: análise de objetivos e de roteiros. In: Seminário Internacional sobre Pesquisa e Estudos Qualitativos, 2004, Bauru. Bauru: USC, 2004,

MARCOVITH, J. A universidade (im)possível. São Paulo: Futura, 1998.

MAXIMIANO, A.C.A. Teoria geral da administração: da revolução urbana à revolução digital. 7.ed. São Paulo: Atlas, 2012.

MEYER Jr., V.; PASCUCCI, L.; MANGOLIN, L. Gestão estratégica: um exame de práticas em universidades privadas. Revista de Administração Pública, v. 46, n. 1, p. 49-70, 2012.

MÜLLER, C. J. Modelo de gestão integrando planejamento estratégico, sistemas de avaliação de desempenho e gerenciamento de processos (MEIO - Modelo de Estratégia, Indicadores e Operações). 2003. Tese (Doutorado em Engenharia) - Universidade Federal do Rio Grande do Sul.

MORGAN, G. Imagens da organização. São Paulo: Atlas, 1996.

MOTTA, P. R. M.O estado da arte da gestão pública. Revista de Administração de Empresas, v. 53, n. 1, p. 82-90, 2013.

PAIM, R. Engenharia de processos: análise do referencial teórico-conceitual, instrumentos, aplicações e casos. 2002. Tese (Dissertação de Mestrado), Universidade Federal do Rio de Janeiro.

PAIM, R.; CARDOSO, V.; CAULLIRAUX, H.; CLEMENTE, R. Gestão de processos: pensar, agir e aprender. Porto Alegre: Ed. Bookman, 2009, 328p.

PESSOA, M. N. M. Gestão das universidades federais brasileiras: um modelo fundamentado no balance scorecard. 2000. Tese (Doutorado em Engenharia de Produção). UFSC.

Florianópolis.

PRADELLA, S.; FURTADO, J. C.; KIPPER, L. M. Gestão de processos: da teoria à prática. São Paulo: Atlas, 141 p., 2012.

RAMOS, M. Fatores críticos na implantação da gestão estratégica de processos: estudo de caso no Tribunal Regional do Paraná. 2011. 153 f. Dissertação (Mestrado em Administração) - Pontifícia Universidade Católica do Paraná, Curitiba, 2011.

ROCKART, J.F. Chief Executives Define Their Own Data Needs. Harvard Business Review, Março-Abril, p.81-85, 1979. 
ROCKART, F. J.; BULLEN, C. A Primer on Critical Success Factors. Center for Information Systems Research, Sloan School of Management, Massachusetts Institute of Technology, 1981.

SALERNO, M. Projeto de organizações integradas e flexíveis: processos, grupos e gestão democrática via espaços de comunicação-negociação. São Paulo: Atlas, 1999.

SALGADO, C. C. R.; AIRES, R. F. F.; WALTER, F.; ARAÚJO, A. G. Contribuições à melhoria de processos organizacionais: uma avaliação empírica sob a perspectiva de mapeamento de processos em uma unidade da Universidade Federal da Paraíba. HOLOS [online], vol.1, 155-168p, 2013.

SAMPIERI, R. H.; COLLADO, C. F.; LUCIO, P. B. Metodologia de pesquisa. 3.ed. São Paulo: MacGraw-Hill, 2006.

SANTOS, H. M.; SANTANA, A. F.; ALVES, C. F. Análise de fatores críticos de sucesso da gestão de processos de negócio em organizações públicas. Revista Eletrônica de Sistemas de Informação, v. 11, n. 1, p. 1-20, 2012.

SANTOS, N. M.; SILVEIRA, R. I. M.; SANTOS, F. M. T. Evolução da teoria organizacional: as perspectivas da teoria sistêmica e da gestão por processos. Gestão Contemporânea, Porto Alegre, ano 8, n. 10, p. 141-164, jul./dez. 2011.

SANTOS, R. Como implementar escritório de processos. Disponível em: http://pt.slideshare.net/Ridlo/como-implementar-escritrio-de-processos. Acesso em 08/10/2015.

SILVA Jr., O. F. Avaliando os sistemas de informações executivas nos processos decisórios das instituições universitárias brasileiras. Florianópolis, 2000. Dissertação (Mestrado em Engenharia de Produção) - Programa de Pós Graduação em Engenharia de Produção, Universidade Federal de Santa Catarina. Florianópolis, 2000.

SMITH, H.; FINGAR, P. Business Process Management (BPM): The Third Wave. Meghan: Kiffer Press; 1st edition, 2007.

STUMPF, I. R. C. Pesquisa bibliográfica. In: DUARTE, J.; BARROS, Antonio (org.). Métodos e técnicas de pesquisa em Comunicação. São Paulo: Atlas, 2005.

TREGEAR, R.; JESUS, L; MACIEIRA, A. Estabelecendo o escritório de processos. Rio de Janeiro: Elo Group, 2010.

VAZ, J. C. Processos de trabalho no setor público: gestão e redesenho. 2008. Disponível em: http://vaz.blog.br/blog/wp-content/uploads/2011/05/texto-revisaoprocessos-revisado1.pdf. Acesso em: 12 de novembro de 2014.

VIEIRA, E. F.; VIEIRA, M. M. F. Funcionalidade burocrática nas universidades federais: conflito em tempos de mudança. Revista de Administração Contemporânea, v. 8, n. 2, p. 181200, abr/jun. 2004. 
WEBER, Max. Economia e sociedade. Tradução Regis Barbosa e Karen Elsabe Barbosa. Volume 1. Brasília, Editora da Universidade de Brasília, 1994.

YIN, R. K. Estudo de caso: planejamento e métodos. Tradução Daniel Grassi. 3.ed. Porto Alegre: Bookman, 2005.

Estudo de caso: planejamento e métodos. Porto Alegre: Bookman, 2015. 


\section{Universidade de Brasília Faculdade UnB Planaltina Programa de Mestrado em Gestão Pública}

Bom dia, meu nome é Kelli Adriane de Carvalho, sou aluna do mestrado profissional em Gestão Pública do Programa de Pós-Graduação em Gestão Pública (PPGP), da Universidade de Brasília. Estou realizando uma investigação a respeito de como a DPR está implantando a gestão por processos na Universidade de Brasília (UnB) no modelo de Escritório de Processos adotado entre o período de 2010 a 2015.Desta forma, este roteiro de entrevista é composto por duas partes, onde a primeira se caracteriza por perguntas relacionadas ao tema objeto deste estudo e a segunda se refere aos dados demográficos do entrevistado. Para tanto, solicito autorização para gravar a entrevista, no intuito de facilitar a posterior transcrição e análise.

Ademais, informo que será mantido sigilo quanto à identificação dos entrevistados e que os dados demográficos são importantes para a caracterização dos participantes do estudo.

Desde já agradeço sua contribuição.

Kelli Adriane de Carvalho Matrícula FUB 1027239

\section{Primeira Parte: perguntas sobre o tema}

1. Fale sobre a origem da gestão por processos na UnB.

Objetivo: identificar o início da gestão por processos na UnB.

2. Qual é o propósito estratégico para a UnB na adoção da gestão por processos?

Objetivo: identificar a razão de ser (objetivo estratégico) das estratégias adotadas pela DPR/UnB.

3. Fale sobre a metodologia adotada para implementação da gestão por processos na UnB.

Objetivo: qual a metodologia aplicada para GP na UnB.

4. Quais são ou foram os processos críticos identificados pela DPR?

Objetivo: identificar se houve algum processo crítico identificado, qual setor e procedimentos adotados pela DPR.

5. Quais são as vantagens na implantação da gestão por processos na UnB?

Objetivo: identificar os fatores que facilitaram a implantação da gestão por processos.

6. Quais são as dificuldades identificadas na implantação da gestão por processos? Objetivo: identificar fatores dificultadores na implantação da gestão por processos. 
Segunda Parte: dados demográficos

\section{Cargo/Função:}

Tempo de trabalho na função:

( ) Até 1 ano, inclusive ( ) Entre 1 e 3 anos, inclusive ( ) Entre 3 e 5 anos, inclusive ( ) Entre 5 e 10 anos, inclusive ( ) Entre 10 e 20 anos, inclusive ( ) Entre 20 e 30 anos, inclusive ( ) Mais de 30 anos

\section{Escolaridade:}

( ) Ensino Fundamental ( ) Ensino Médio ( ) Superior Incompleto ( ) Superior Completo ( ) Especialização ( ) Mestrado ( ) Doutorado ( ) Outro:

\section{Tempo de trabalho na UnB:}

( ) Até 1 ano, inclusive ( ) Entre 1 e 3 anos, inclusive ( ) Entre 3 e 5 anos, inclusive ( ) Entre 5 e 10 anos, inclusive ( ) Entre 10 e 20 anos, inclusive ( ) Entre 20 e 30 anos, inclusive ( ) Mais de 30 anos

\section{Faixa Etária:}

( ) 20 a 30 anos ( ) 31 a 40 anos ( ) 41 a 50 anos ( ) 51 a 60 anos ( ) acima 61 anos 


\section{APÊNDICE B}

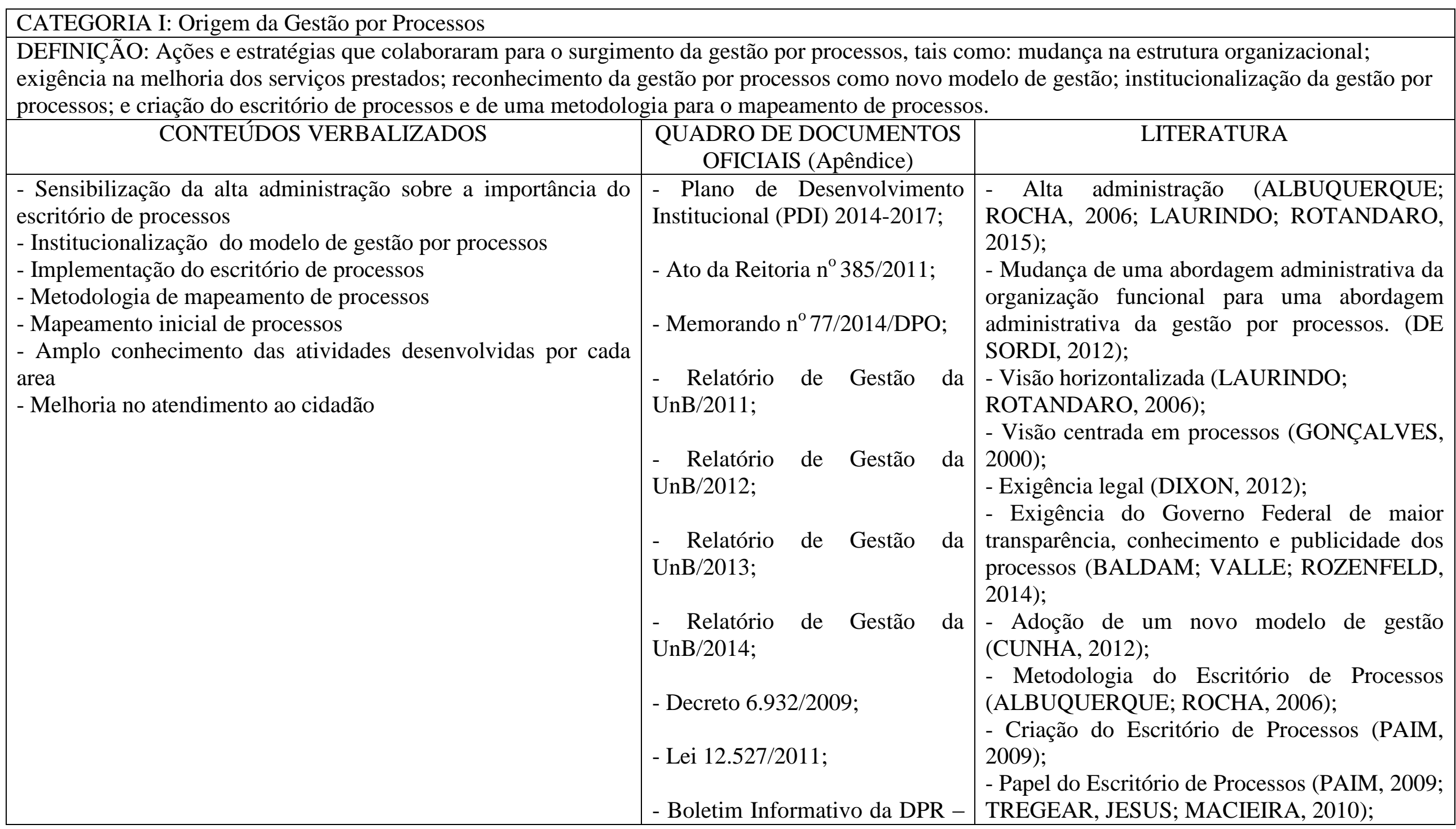




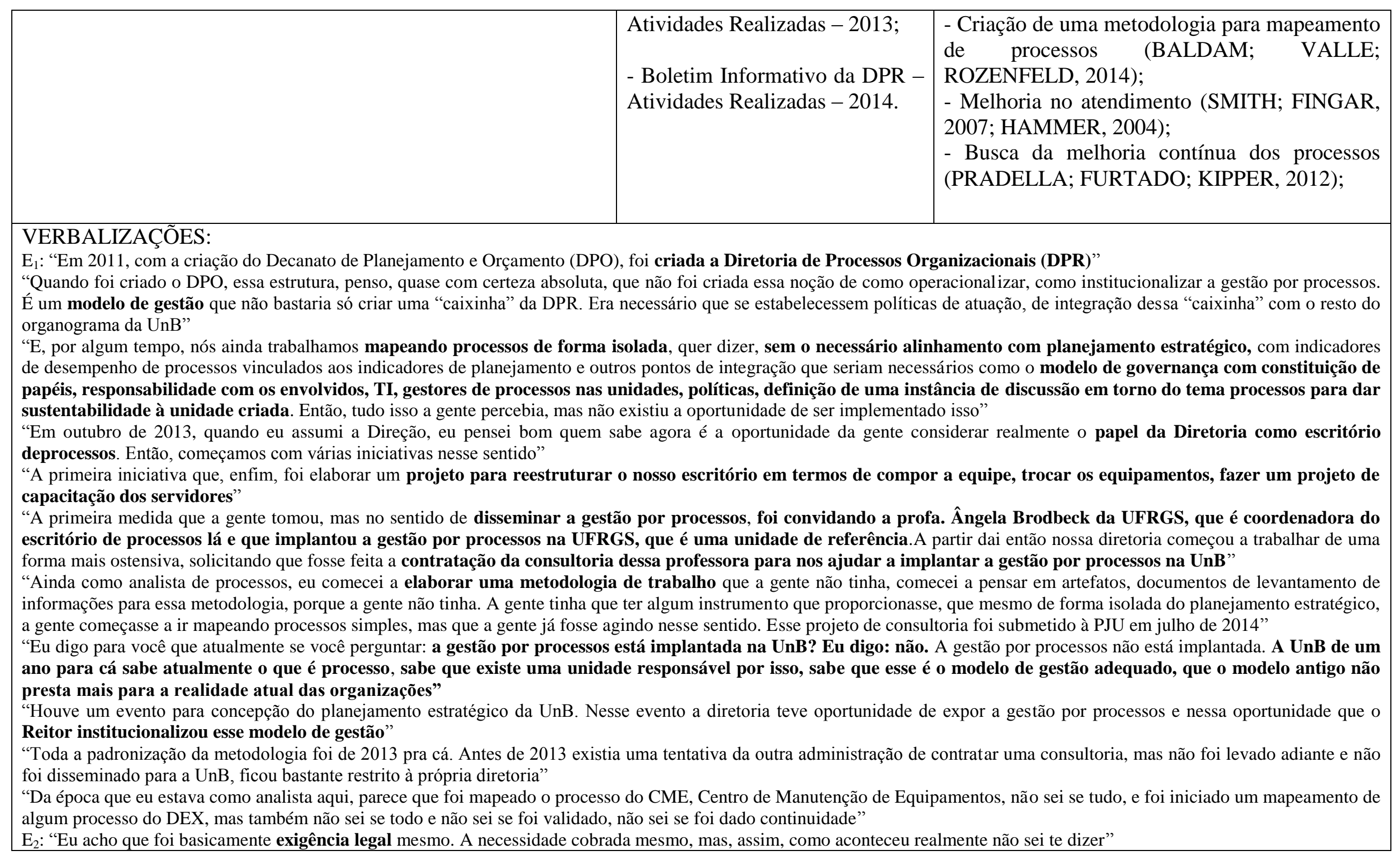


$\mathrm{E}_{3}$ : "Eu estou aqui há apenas um ano, então quando eu cheguei já existia, essa iniciativa já estava bem no seu começo, também não estava nada tão desenvolvido,

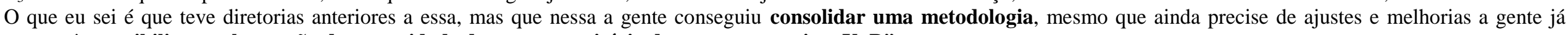
conseguiu sensibilizar a alta gestão da necessidade de ter um escritório de processos aqui na UnB"

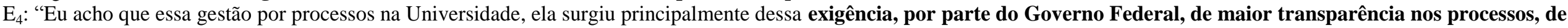
maior conhecimento e publicidade desses processos"

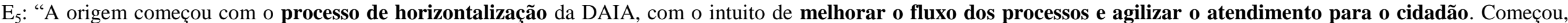
mais ou menos, em abril/maio de 2015"

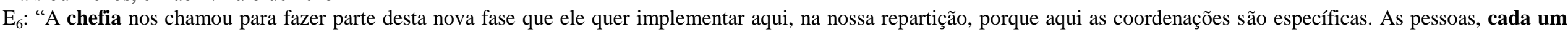

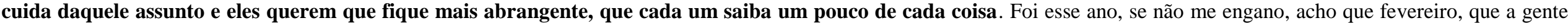
começou com as reuniões para cada um ir interagindo com as outras pessoas"

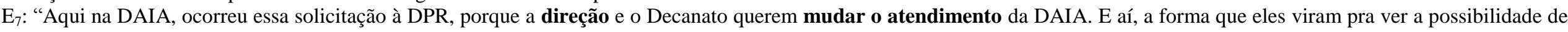
implementar essa mudança seria pelo mapeamento e como a DPR implementou isso agora, eles convidaram pra fazer isso aqui. Começou esse ano de 2015 "

$\mathrm{E}_{8}$ : "Basicamente, na minha area de atuação, não tem nada de gestão de processos"

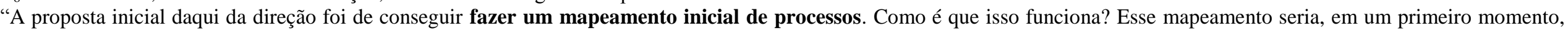

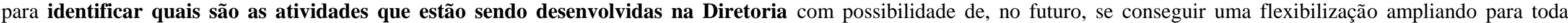
diretoria"

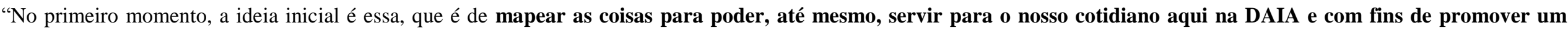

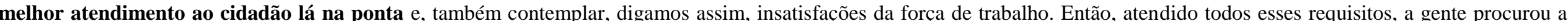
DPR, com fins de fazer esse trabalho com a gente"

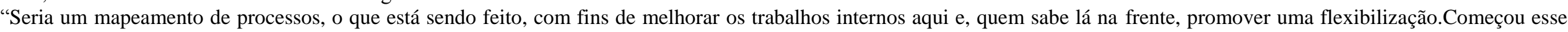
ano de 2015, em janeiro"

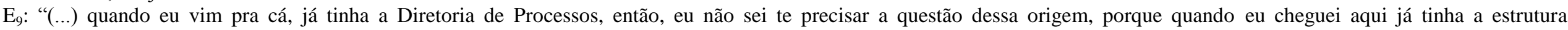
organizacional"

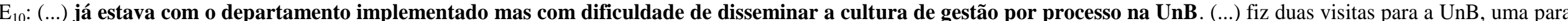

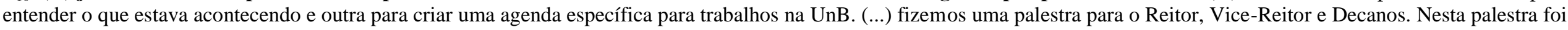

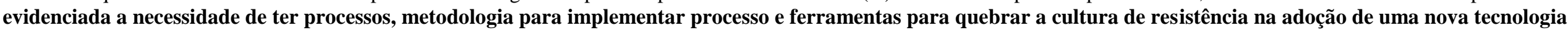

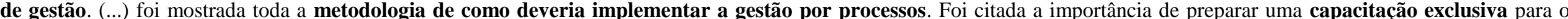

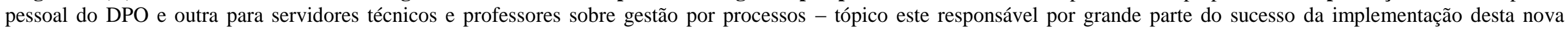
tecnologia de gestão.’ 


\section{APÊNDICE C}

\begin{tabular}{|c|c|c|}
\hline $\begin{array}{l}\text { ÃO: As organizações, com as suas especifi } \\
\text { repensar a forma de gestão e adotar o mo } \\
\text { visão de futuro; definição da governança dos }\end{array}$ & entam & $\mathrm{am}$ \\
\hline CONTEÚDOS VERBALIZADOS & $\begin{array}{l}\text { QUADRO DE DOCUMENTOS } \\
\text { OFICIAIS (Apêndice) }\end{array}$ & LITERATURA \\
\hline $\begin{array}{l}\text { - Alcance da missão e visão de futuro da organização, } \\
\text { utilizando um modelo de excelência de gestão; } \\
\text { - Definição, institucionalização e promoção de } \\
\text { governança por processos; } \\
\text { - Propiciar o conhecimento dos fluxos dos processos da } \\
\text { organização (identificação; definição do início e fim; } \\
\text { identificação dos subprocessos e saídas; e descrição das } \\
\text { atividades) e quem são os responsáveis; } \\
\text { - Capacitar os servidores para que se sintam motivados } \\
\text { e almejem pelo crescimento individual e profissional; } \\
\text { - Fomentar práticas de melhorias; } \\
\text { - Mudança de uma visão funcional para uma visão por } \\
\text { processos; } \\
\text { - Integração entre as unidades organizacionais. }\end{array}$ & $\begin{array}{l}\text { - Plano de Desenvolvimento Institucional } \\
\text { (PDI) 2014-2017, de 18/09/2014; } \\
\text { - Memorando } \mathrm{n}^{\mathrm{o}} \text { 77/2014/DPO, de } \\
\text { 28/04/2014; } \\
\text { - Relatório de Gestão da UnB/2013, de } \\
\text { 05/03/2014; } \\
\text { - Relatório de Gestão da UnB/2014, de } \\
\text { 05/03/2015; } \\
\text { - Boletim Informativo da DPR - } \\
\text { Atividades Realizadas - 2013, de } \\
\text { 01/01/2014; } \\
\text { - Boletim Informativo da DPR - } \\
\text { Atividades Realizadas - 2014, de } \\
01 / 01 / 2015 \text {. }\end{array}$ & $\begin{array}{l}\text { - Conhecer o fluxo dos processos da } \\
\text { organização e os responsáveis (JESUS; } \\
\text { MACIEIRA, 2014; MANUAL DE BPM } \\
\text { CBOK, 2013; GONÇALVES, 2000; } \\
\text { ALBUQUERQUE; ROCHA, 2006; PAIM etal., } \\
\text { 2009). } \\
\text { - Definição do modelo de governança dos } \\
\text { processos (SANTOS, 2014; JESUS; } \\
\text { MACIEIRA, 2014; BALDAM; VALLE; } \\
\text { ROZENFELD, 2014; PAIM et al.,2009). } \\
\text { - Horizontalização e integração entre as } \\
\text { unidades organizacionais (GONÇALVES, 2000; } \\
\text { LAURINDO; ROTANDARO, 2006). } \\
\text { - Crescimento individual e profissional dos } \\
\text { funcionários (DE SORDI, 2012; MANUAL DE } \\
\text { BPM CBOK, 2013; BALDAM; VALLE; } \\
\text { ROZENFELD, 2014; ALBUQUERQUE; } \\
\text { ROCHA, 2006; DAVENPORT, 1994). } \\
\text { - Proporcionar melhorias relacionadas aos } \\
\text { processos, serviços, atendimento, gestão }\end{array}$ \\
\hline
\end{tabular}




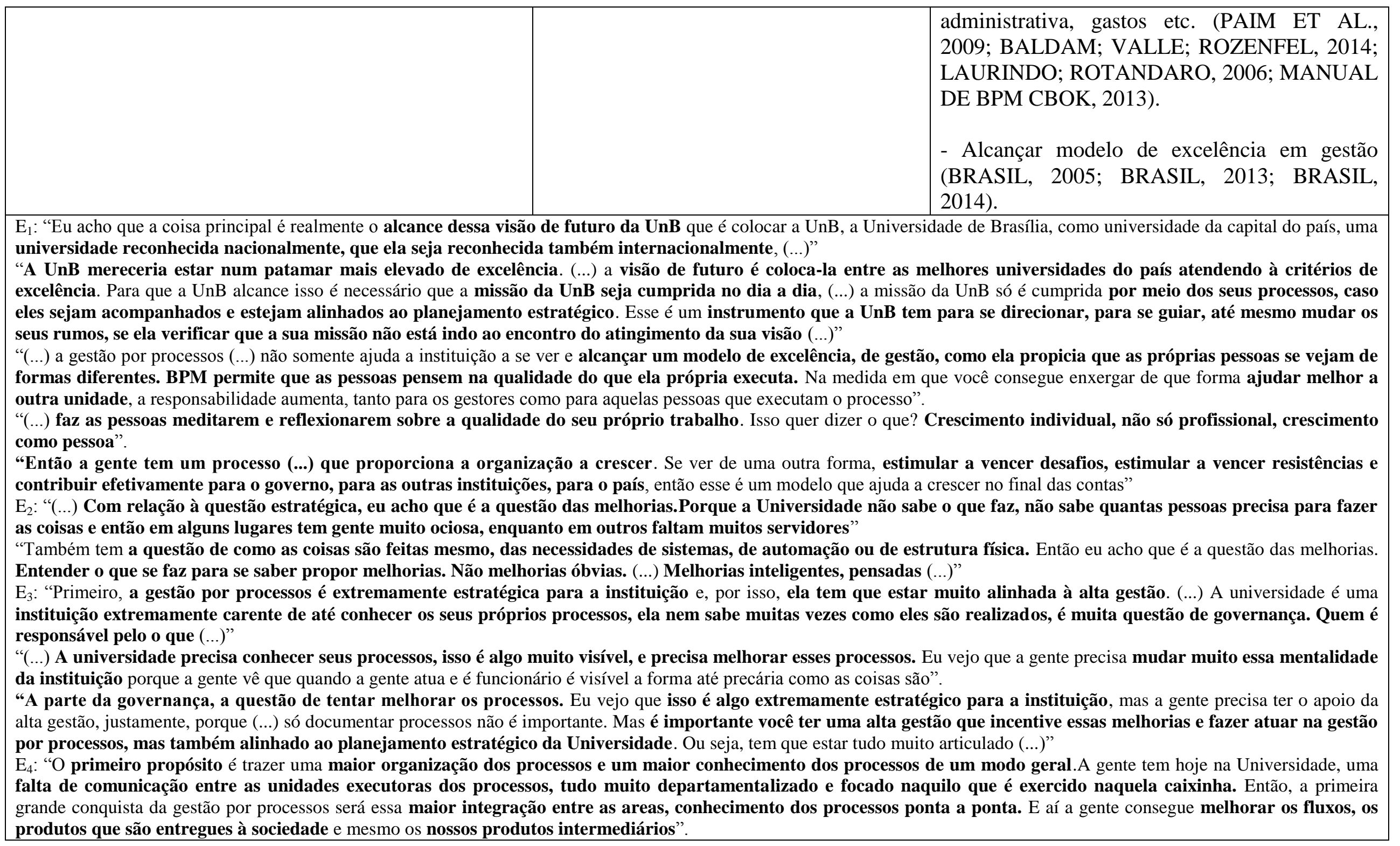


E 5: "É melhorar o atendimento e passar pelo processo de horizontalização da DAIA que hoje é departamentalizado e a direção quer que seja horizontalizado".

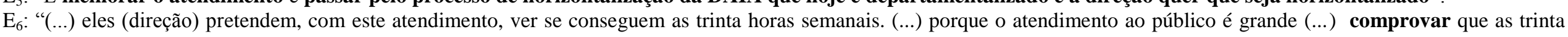
horas, que o atendimento, o tempo todo, ininterrupto, que seria vantagem",

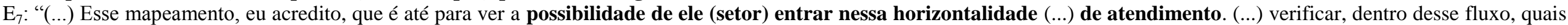
são as possibilidades que vão ter para poder entrar nesse novo atendimento".

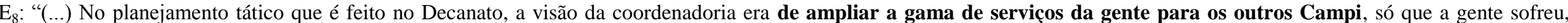

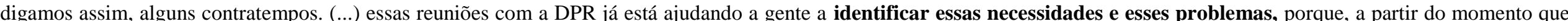

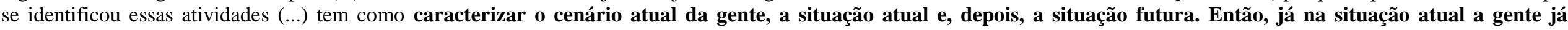

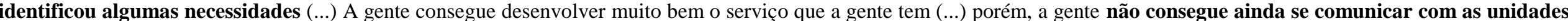

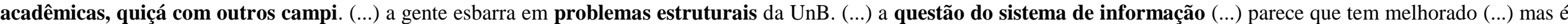
uma questão que vai engatinhando (...)"

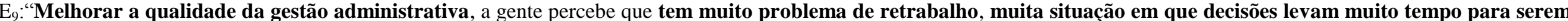

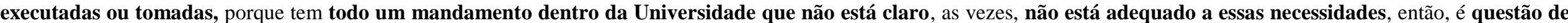

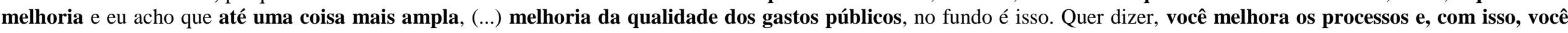
melhora a quantidade, a saída dos produtos que você tem com aqueles mesmos recursos, é basicamente isso."

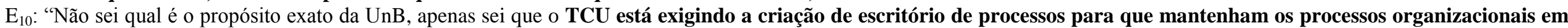

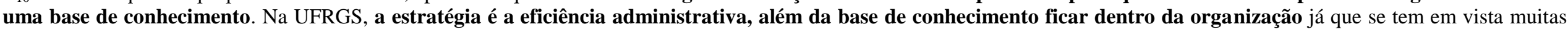
aposentadorias". 


\section{APÊNDICE D}

CATEGORIA III: Vantagens na adoção da gestão por processos

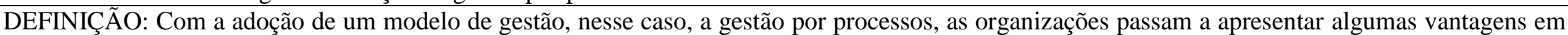

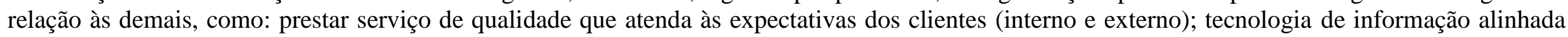
aos processos; unidades organizacionais integradas; informações transparentes e de livre acesso; e melhoria contínua.

\begin{tabular}{|c|c|c|}
\hline CONTEÚDOS VERBALIZADOS & $\begin{array}{c}\text { QUADRO DE DOCUMENTOS } \\
\text { OFICIAIS (Apêndice) }\end{array}$ & LITERATURA \\
\hline $\begin{array}{l}\text { - Integração entre as unidades organizacionais; } \\
\text { - Alinhamento entre tecnologia de informação e processos; } \\
\text { - Prestação de serviço de qualidade, atendendo às } \\
\text { expectativas dos clientes (interno e externo); } \\
\text { - Transparência em relação à execução dos processos; } \\
\text { - Promoção de melhorias. }\end{array}$ & $\begin{array}{l}\text { - Plano de } \\
\text { Institucional (PDI) } \\
\text { 2014-2017; }\end{array}$ & $\begin{array}{l}\text { - Alinhamento entre tecnologia da informação e } \\
\text { gestão por processos (DAVENPORT, 1994; } \\
\text { JESUS; MACIEIRA, 2014; BALDAM; } \\
\text { VALLE; ROZENFELD, 2014) } \\
\text { - Melhoria contínua (LAURINDO; } \\
\text { ROTANDARO, 2006) } \\
\text { - Melhoria dos processos (BALDAM; VALLE; } \\
\text { ROZENFELD, 2014; PAIM et al, 2009; CRUZ, } \\
\text { 2012) } \\
\text { Eliminação de desperdícios (BIAZZI; } \\
\text { MUSCAT; BIAZZI, 2011; BALDAM; VALLE; } \\
\text { ROZENFELD, 2014; FILHO, 2011) } \\
\text { - Redução da burocracia (VAZ, 2008; BIAZZI; } \\
\text { MUSCAT; BIAZZI, 2011) } \\
\text { - Conhecimento do fluxo dos processos } \\
\text { (ALBUQUERQUE; ROCHA, 2006; MANUAL } \\
\text { BPM CBOK, 2013) } \\
\text { - Integração entre as unidades organizacionais }\end{array}$ \\
\hline
\end{tabular}




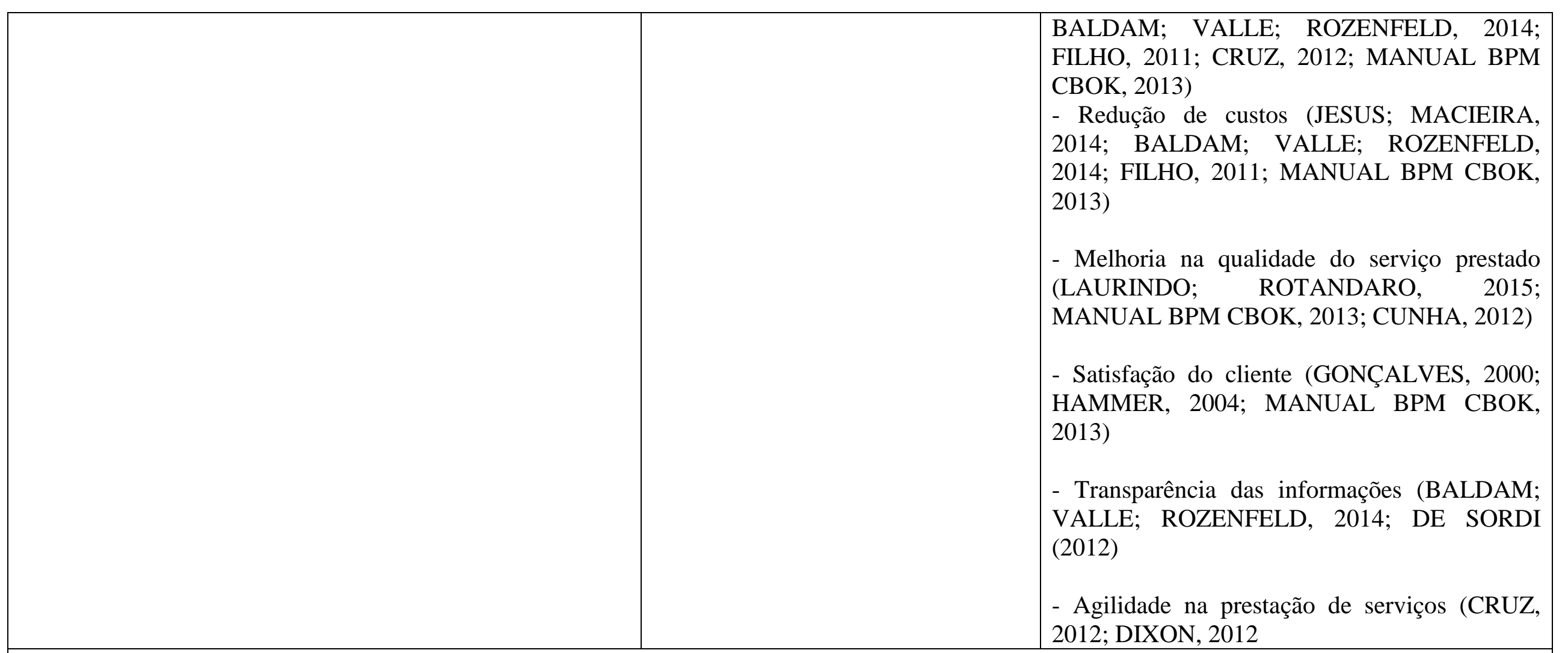

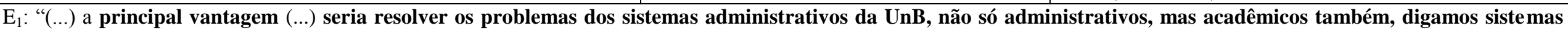

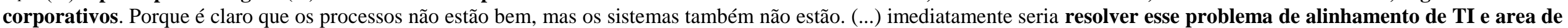

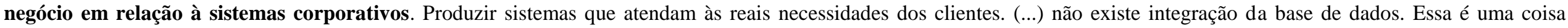
pontual. (...) essa interação, que a TI pudesse realmente prover sistemas corporativos mais alinhados com a necessidade."

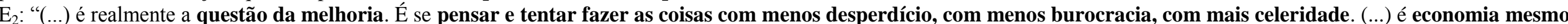

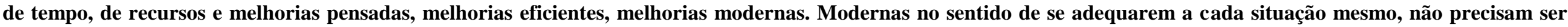
coisas tecnológicas ou caras, coisas eficientes para cada caso."

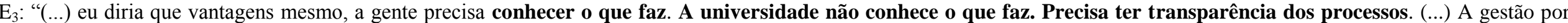

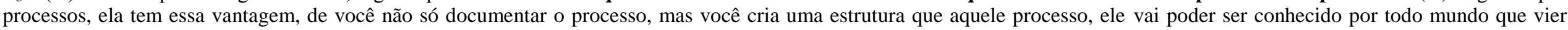

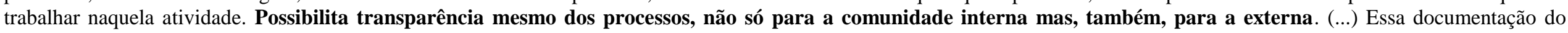

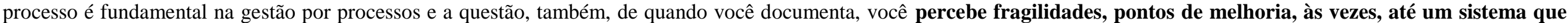

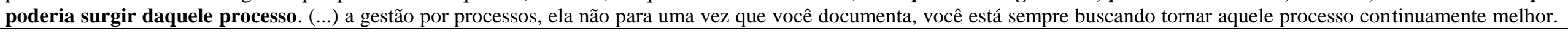




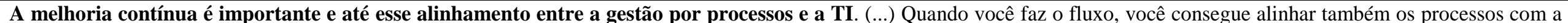
area de TI da Universidade."

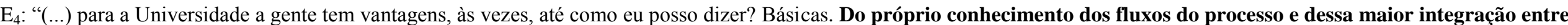

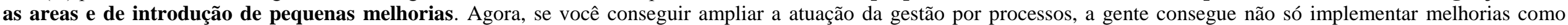

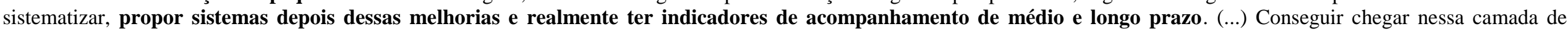

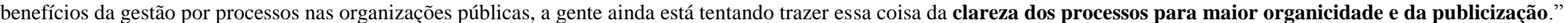

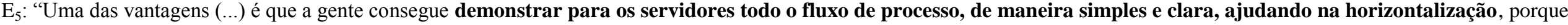
os servidores conseguem visualizar melhor os processos e fica de modo bem claro pra ele, tanto por parte da chefia explicar, quanto para a administração geral."

$\mathrm{E}_{6}$ : "É o melhor atendimento. Tentar um atendimento mais rápido para o público (...) é tentar atender mais rápido, uma coisa mais eficiente."

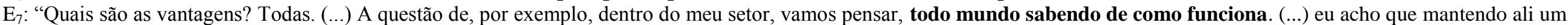

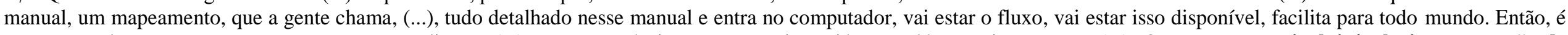

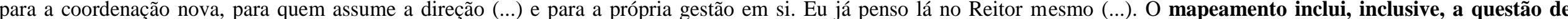

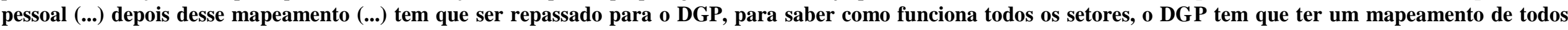

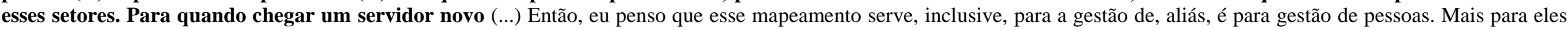
até, porque eles vão saber: olha, quando eu convoquei o servidor novo, eu sei que lá precisa, porque tem esse atendimento (...), e tudo pelo mapeamento..."

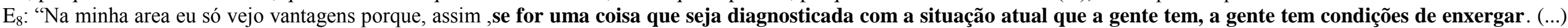

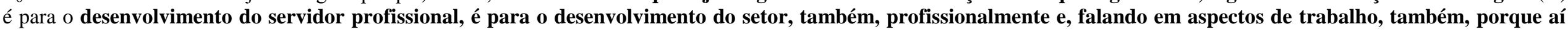

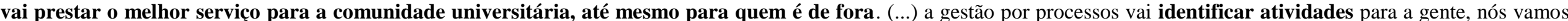

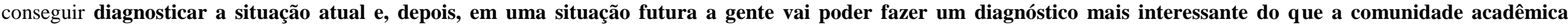
necessita e do que esses futuros profissionais vão precisar no mercado de trabalho."

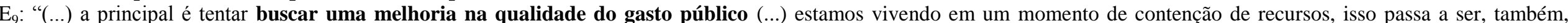

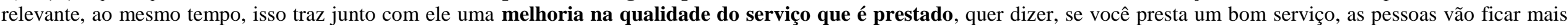
felizes, vão ter uma resposta melhor, então, eu acho que são essas coisa, satisfação do nosso usuário no final."

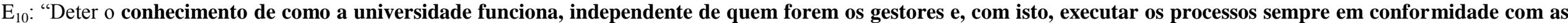
exigências legais". 


\section{APÊNDICE E}

\begin{tabular}{|c|c|c|}
\hline \multicolumn{3}{|c|}{$\begin{array}{l}\text { CATEGORIA IV: Dificultadores para a implantação da gestão por processos } \\
\text { DEFINIÇÃO: Elementos que dificultam a implantação da gestão por processos nas organizações, porém, quando executados de maneira correta, são } \\
\text { conhecidos como fatores críticos de sucessos. São fatores dificultadores: cultura organizacional; falta da disseminação da visão por processos; } \\
\text { resistência à mudança; falta de apoio da alta administração; falta de comprometimento dos funcionários; infraestrutura precária; falta de capacitação } \\
\text { para os funcionários etc. }\end{array}$} \\
\hline CONTEÚDOS VERBALIZADOS & $\begin{array}{l}\text { QUADRO DE DOCUMENTOS } \\
\text { OFICIAIS (Apêndice) }\end{array}$ & LITERATURA \\
\hline $\begin{array}{l}\text { - Falta de uma cultura organizacional voltada para o } \\
\text { gerenciamento por processos; } \\
\text { - Resistência às mudanças originadas da gestão por processos; } \\
\text { - Falta de programas de capacitação sobre gerenciamento por } \\
\text { processos voltados para os servidores; } \\
\text { - Utilização de uma metodologia de modelagem de processos } \\
\text { inadequada; } \\
\text { - Falta de denominação de uma unidade organizacional como } \\
\text { Escritório de Processos com infraestrutura adequada; } \\
\text { - Falta de envolvimento mais ativo por parte da alta } \\
\text { administração no apoio à gestão por processos. }\end{array}$ & $\begin{array}{l}\text { - Plano de Desenvolvimento } \\
\text { Institucional (PDI 2014-2017), } \\
\text { de 18/09/2014; } \\
\text { - Relatório de Gestão 2012, de } \\
\text { 01/03/2013; } \\
\text { - Relatório de Gestão 2013, de } \\
\text { 05/03/2014; } \\
\text { - Relatório de Gestão 2014, de } \\
\text { 05/03/2015; }\end{array}$ & $\begin{array}{l}\text { - Cultura organizacional (CARBONE, 2000; } \\
\text { FILHO (2011); ALBUQUERQUE; ROCHA, } \\
\text { (2006); FILHO (2011). } \\
\text { - Falta de capacitação de funcionários (GUIA } \\
\text { BPM CBOK V3.0, 2013; ALBUQUERQUE; } \\
\text { ROCHA, 2006; BALDAM; VALLE; } \\
\text { ROZENFELD, 2014; RAMOS, 2011; } \\
\text { ALMEIDA, 2002). } \\
\text { - Infraestrutura precária (JESUS; MACIEIRA, } \\
\text { 2014; BALDAM; VALLE; ROZENFELD, } \\
\text { 2014; TREGEAR; JESUS; MACIEIRA, 2010; } \\
\text { PAIM et al., 2009). } \\
\text { - Resistência à mudança (VIEIRA; VIEIRA, } \\
\text { 2004; JUNQUILHO, 2004). } \\
\text { - Falta de apoio da alta administração } \\
\text { (LAURINDO; ROTANDARO, } 2015 \text {; } \\
\text { BALDAM; VALLE; ROZENFELD, 2014) } \\
\text { - Falta de conhecimento do que vem a ser gestão }\end{array}$ \\
\hline
\end{tabular}




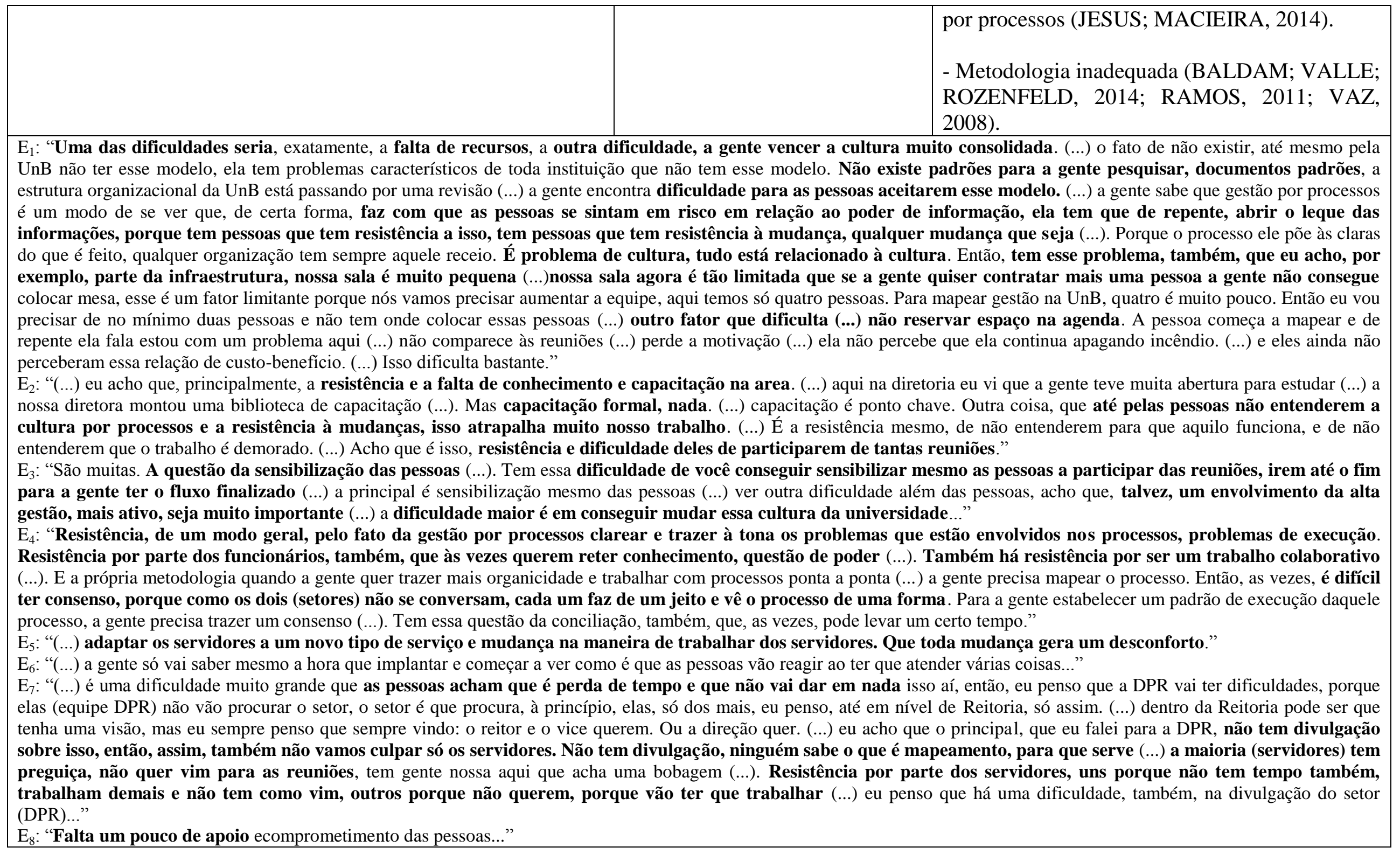




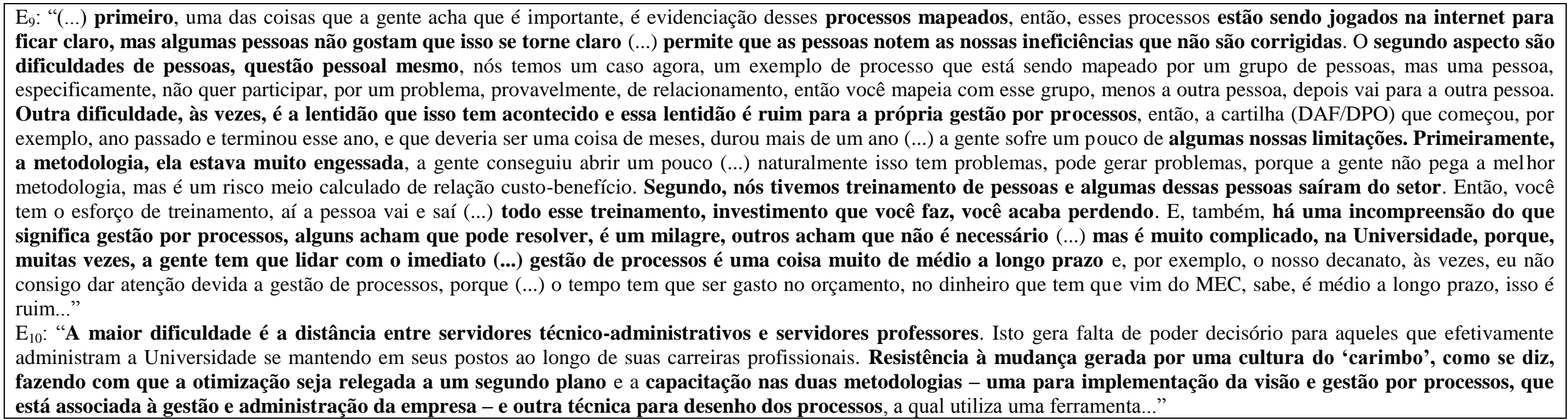




\section{APÊNDICE F}

\section{PLANILHA DE DOCUMENTOS PARA A PESQUISA}

\begin{tabular}{|c|c|c|c|c|c|c|c|}
\hline $\begin{array}{c}\text { IDENTIFICAÇÃO } \\
\text { DO } \\
\text { DOCUMENTO }\end{array}$ & DOCUMENTO & $\begin{array}{c}\text { DATA DE } \\
\text { PUBLICAÇÃOO }\end{array}$ & FINALIDADE & PRINCIPAIS INFORMAÇÕES & CATEGORIAS & ORIGEM & ABRANGÊNCIA \\
\hline \multirow[t]{2}{*}{ Doc1 } & \multirow{2}{*}{$\begin{array}{c}\text { Plano de } \\
\text { Desenvolvimento } \\
\text { Institucional (PDI) } \\
2014-2017\end{array}$} & \multirow[t]{2}{*}{ 18/09/2014 } & $\begin{array}{c}\text { O Plano de } \\
\text { Desenvolvimento } \\
\text { Institucional - PDI - } \\
\text { consiste num documento } \\
\text { em que se definem a } \\
\text { missão da instituição de } \\
\text { ensino superior e as } \\
\text { estratégias para atingir } \\
\text { suas metas e objetivos. } \\
\text { Abrangendo um período de } \\
\text { cinco anos, deverá } \\
\text { contemplar o cronograma e } \\
\text { a metodologia de } \\
\text { implementação dos } \\
\text { objetivos, metas e ações do } \\
\text { Plano }\end{array}$ & $\begin{array}{l}\text { Revisão do planejamento estratégico } \\
\text { da UnB com a participação do DPO, } \\
\text { equipe de especialistas e todas as } \\
\text { unidades integrantes da administração } \\
\text { central da instituição através dos seus } \\
\text { representantes. Tendo por objetivo a } \\
\text { redefinição da missão, visão, foco de } \\
\text { atuação, identificação dos elementos } \\
\text { relacionados ao ambiente interno e } \\
\text { externo, bem como pontos fortes, } \\
\text { fracos, oportunidades e ameaças e } \\
\text { exercício preliminar de objetivos } \\
\text { estratégicos para 2015-2019. } \\
\text { (março/2014) }\end{array}$ & \multirow[t]{2}{*}{ CI; CII; CIII;CIV } & \multirow[t]{2}{*}{ DPO } & \multirow[t]{2}{*}{ UnB } \\
\hline & & & $\begin{array}{l}\text { a coerência e a articulação } \\
\text { entre as diversas ações, a } \\
\text { manutenção de padrões de } \\
\text { qualidade e, quando } \\
\text { pertinente, o orçamento. } \\
\text { Deverá apresentar, ainda, } \\
\text { um quadro-resumo } \\
\text { contendo a relação dos } \\
\text { principais indicadores de } \\
\text { desempenho, que } \\
\text { possibilite comparar, para } \\
\text { cada um, a situação atual e } \\
\text { futura (após a vigência do } \\
\text { PDI) }\end{array}$ & $\begin{array}{l}\text { Definição da Missão: Ser uma } \\
\text { instituição inovadora, comprometida } \\
\text { com a excelência acadêmica, científica } \\
\text { e tecnológica, formando cidadãos } \\
\text { conscientes do seu papel } \\
\text { transformados na sociedade, } \\
\text { respeitadas a ética e a valorização de } \\
\text { identidades e culturas com } \\
\text { responsabilidade social. }\end{array}$ & & & \\
\hline
\end{tabular}




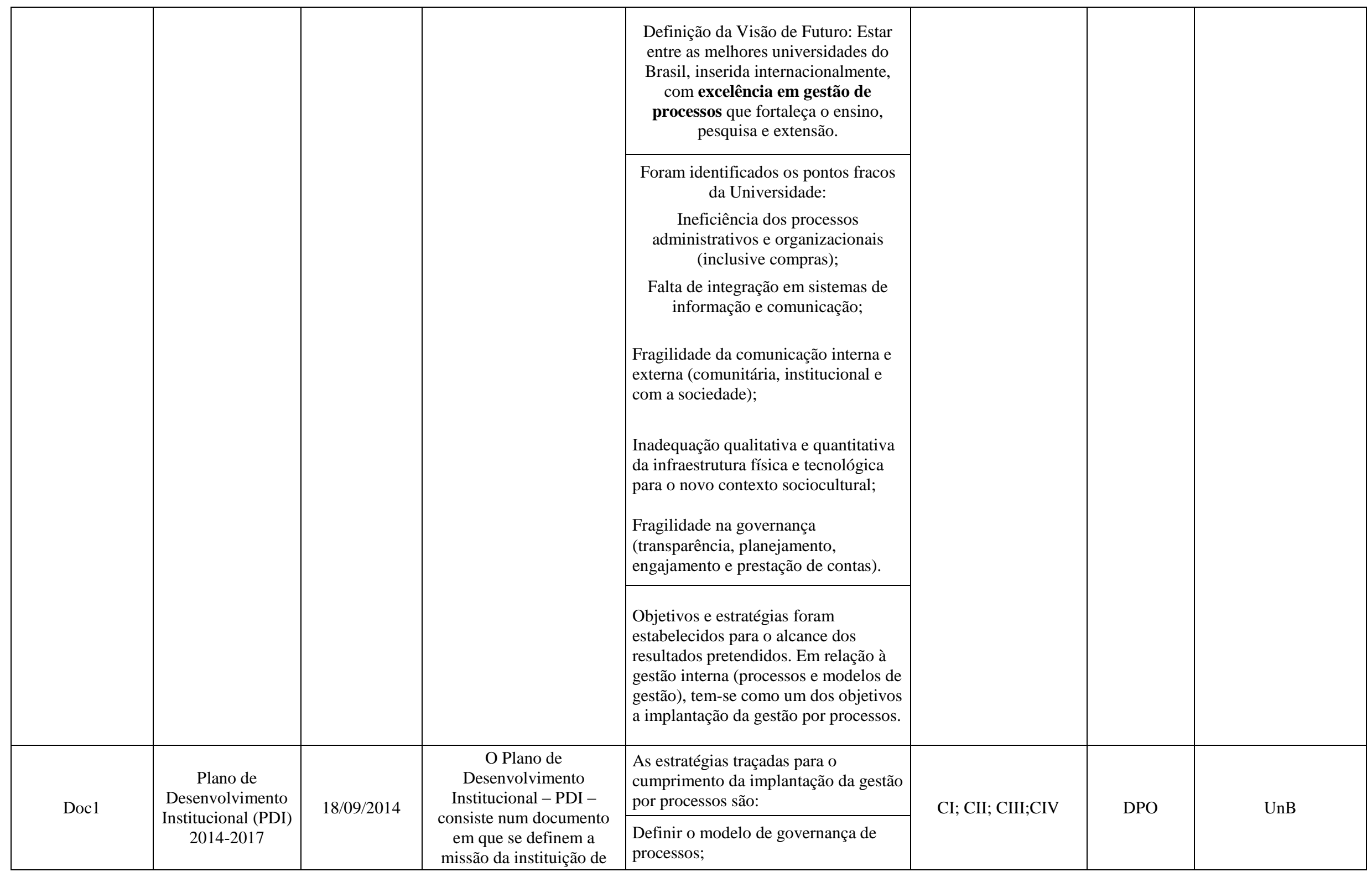




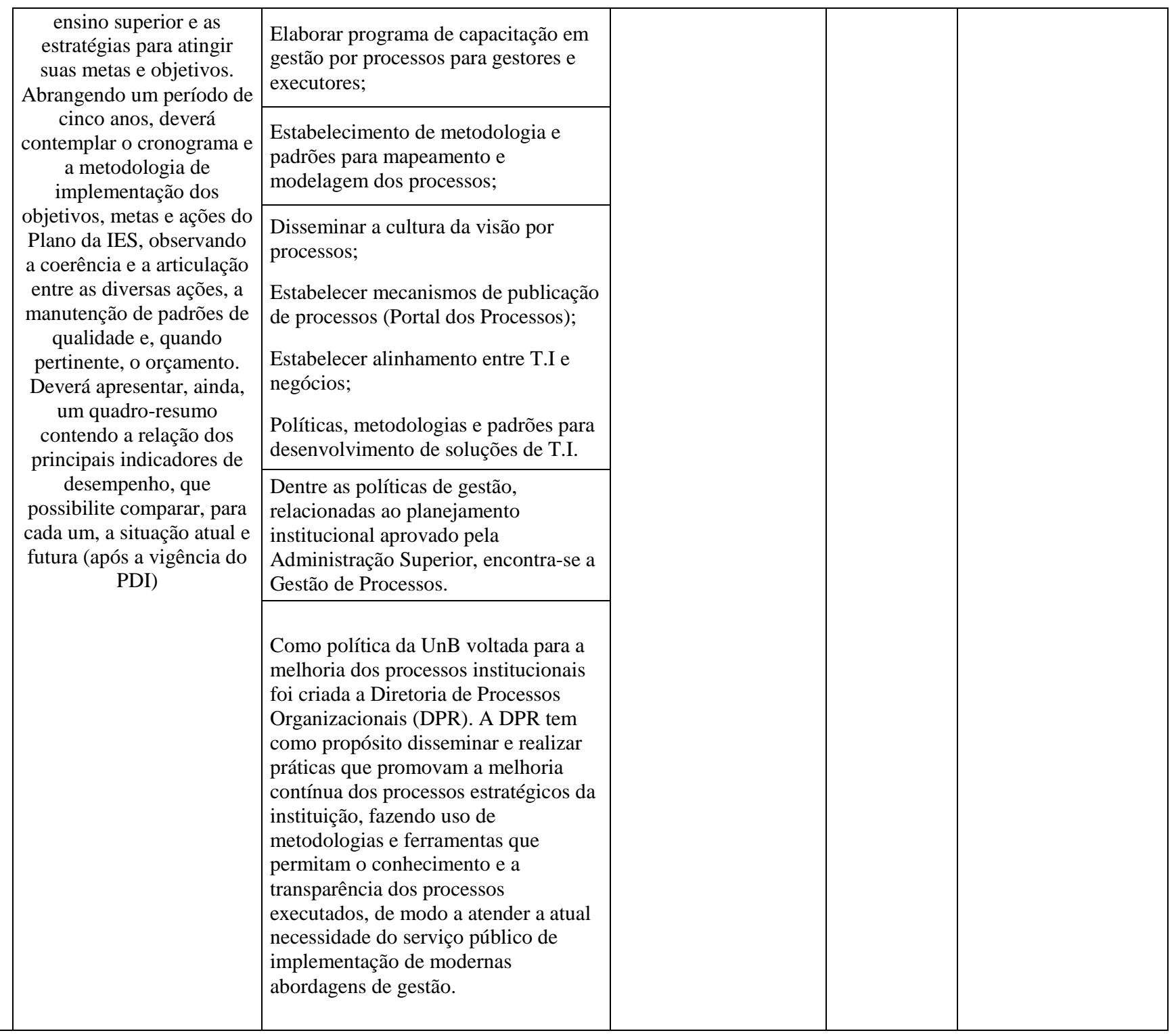




\begin{tabular}{|c|c|c|c|c|c|c|c|}
\hline & & & & $\begin{array}{l}\text { O Reitor institucionalizou o enfoque } \\
\text { administrativo de Gestão por } \\
\text { Processos na UnB. }\end{array}$ & & & \\
\hline & & & & $\begin{array}{l}\text { A gestão por processo poderá } \\
\text { melhorar substancialmente a } \\
\text { eficiência, a eficácia e a efetividade da } \\
\text { administração, reduzindo a burocracia } \\
\text { e economizando recursos. }\end{array}$ & & & \\
\hline Doc2 & $\begin{array}{c}\text { Ato da Reitoria } \mathrm{n}^{\circ} \\
385 / 2011\end{array}$ & $18 / 03 / 2011$ & \begin{tabular}{c|} 
Aprova a estrutura \\
organizacional do \\
Decanato de Planejamento \\
e Orçamento, e dá outras \\
providências
\end{tabular} & $\begin{array}{l}\text { Constitui a estrutura organizacional do } \\
\text { DPO. Nessa estrutura encontra-se a } \\
\text { Diretoria de Processos } \\
\text { Organizacionais (DPR). }\end{array}$ & CI & Reitor & UnB \\
\hline \multirow{4}{*}{ Doc3 } & \multirow{4}{*}{$\begin{array}{l}\text { Memorando } \mathrm{n}^{\circ} \\
\text { 77/2014/DPO }\end{array}$} & \multirow{4}{*}{ 28/04/2014 } & \multirow{4}{*}{$\begin{array}{l}\text { Implantação da Gestão por } \\
\text { Processos na Universidade } \\
\text { de Brasília }\end{array}$} & 1. Adoção de uma visão por processos. & \multirow{4}{*}{ CI; CII } & \multirow{4}{*}{ DPR/DPO } & \multirow{4}{*}{ Magnífico Reitor } \\
\hline & & & & $\begin{array}{l}\text { 2. Manifestação pelas unidades da } \\
\text { UnB do conhecimento dos seus } \\
\text { processos organizacionais e } \\
\text { consequente implementação de } \\
\text { melhorias. DPR realizou mapeamento } \\
\text { dos processos do DPO está mapeando } \\
\text { os processos do Arquivo Central } \\
\text { (ACE) e de alguns processos } \\
\text { executados pelo DAF. }\end{array}$ & & & \\
\hline & & & & $\begin{array}{l}\text { 3. Solicitação de mapeamento dos } \\
\text { processos da Diretoria de Manutenção } \\
\text { e Equipamentos (DIMEQ). }\end{array}$ & & & \\
\hline & & & & $\begin{array}{l}\text { 4. Com a implantação da governança } \\
\text { de TI se faz necessária a adoção de } \\
\text { gestão por processos como pré- } \\
\text { requisito. }\end{array}$ & & & \\
\hline
\end{tabular}




\begin{tabular}{|c|c|c|c|c|c|c|c|}
\hline & & & & $\begin{array}{l}\text { 5. Solicitação ao Reitor da } \\
\text { institucionalização do enfoque } \\
\text { administrativo Gestão por Processos } \\
\text { na UnB quando diretrizes e } \\
\text { procedimentos serão estabelecidos } \\
\text { para disciplinar a gestão de processos } \\
\text { organizacionais no âmbito da } \\
\text { Instituição. }\end{array}$ & & & \\
\hline & & & & $\begin{array}{l}\text { De acordo do Reitor com a } \\
\text { institucionalização da gestão por } \\
\text { processos na UnB }\end{array}$ & & & \\
\hline Doc4 & $\begin{array}{l}\text { Relatório de } \\
\text { Gestão } 2011\end{array}$ & 01/03/2012 & $\begin{array}{c}\text { Relatório de Gestão do } \\
\text { exercício de } 2011 \\
\text { apresentado aos } \\
\text { órgãos de controle interno } \\
\text { e externo como prestação } \\
\text { de contas } \\
\text { ordinária anual a que esta } \\
\text { Unidade está obrigada nos } \\
\text { termos do art. } 70 \text { da } \\
\text { Constituição Federal, } \\
\text { elaborado de acordo com } \\
\text { as } \\
\text { disposições da Instrução } \\
\text { Normativa TCU no } \\
\text { 63/2010, da } \\
\text { Decisão Normativa TCU } \\
n^{\circ} 108 / 2010 \text { e da Portaria } \\
\text { TCU n }{ }^{\circ} \\
\text { 123/2011 e das orientações } \\
\text { do órgão de controle } \\
\text { interno. }\end{array}$ & $\begin{array}{l}\text { Dentre os objetivos estratégicos } \\
\text { consta: "Ter excelência e transparência } \\
\text { na comunicação institucional, em } \\
\text { ações de tecnologia da informação, na } \\
\text { gestão de meios, do patrimônio e de } \\
\text { processos. Areas estratégicas: } \\
\text { Planejamento e Gestão (DPO), } \\
\text { Tecnologia da Informação e da } \\
\text { Comunicação (DPO, CPD), } \\
\text { Comunicação Institucional e } \\
\text { Informações (SECOM) e Captação de } \\
\text { Recursos, Prestação de Serviços e } \\
\text { Gestão Patrimonial (CESPE, CDT, } \\
\text { DAF, SGP/SEI). }\end{array}$ & $\mathrm{CI}$ & UnB & TCU e UnB \\
\hline
\end{tabular}




\begin{tabular}{|c|c|c|c|c|c|c|c|}
\hline Doc4 & $\begin{array}{l}\text { Relatório de } \\
\text { Gestão } 2011\end{array}$ & $01 / 03 / 2012$ & $\begin{array}{c}\text { Relatório de Gestão do } \\
\text { exercício de } 2011 \\
\text { apresentado aos } \\
\text { órgãos de controle interno } \\
\text { e externo como prestação } \\
\text { de contas } \\
\text { ordinária anual a que esta } \\
\text { Unidade está obrigada nos } \\
\text { termos do art. } 70 \text { da } \\
\text { Constituição Federal, } \\
\text { elaborado de acordo com } \\
\text { as } \\
\text { disposições da Instrução } \\
\text { Normativa TCU no } \\
63 / 2010, \text { da } \\
\text { Decisão Normativa TCU } \\
\mathrm{n}^{\circ} \text { 108/2010 e da Portaria } \\
\text { TCU no } \\
\text { 123/2011 e das orientações } \\
\text { do órgão de controle } \\
\text { interno. }\end{array}$ & $\begin{array}{l}\text { Para o alcance dos objetivos } \\
\text { estratégicos foram traçadas metas com } \\
\text { indicadores e ações para seu alcance. } \\
\text { Dentre elas, documentar os processos } \\
\text { organizacionais críticos até 2015. A } \\
\text { ação para o seu alcance era "envolver } \\
\text { as Unidades nas ações de } \\
\text { identificação, mapeamento, desenho e } \\
\text { documentação dos processos } \\
\text { organizacionais. }\end{array}$ & $\mathrm{CI}$ & UnB & TCU e UnB \\
\hline
\end{tabular}




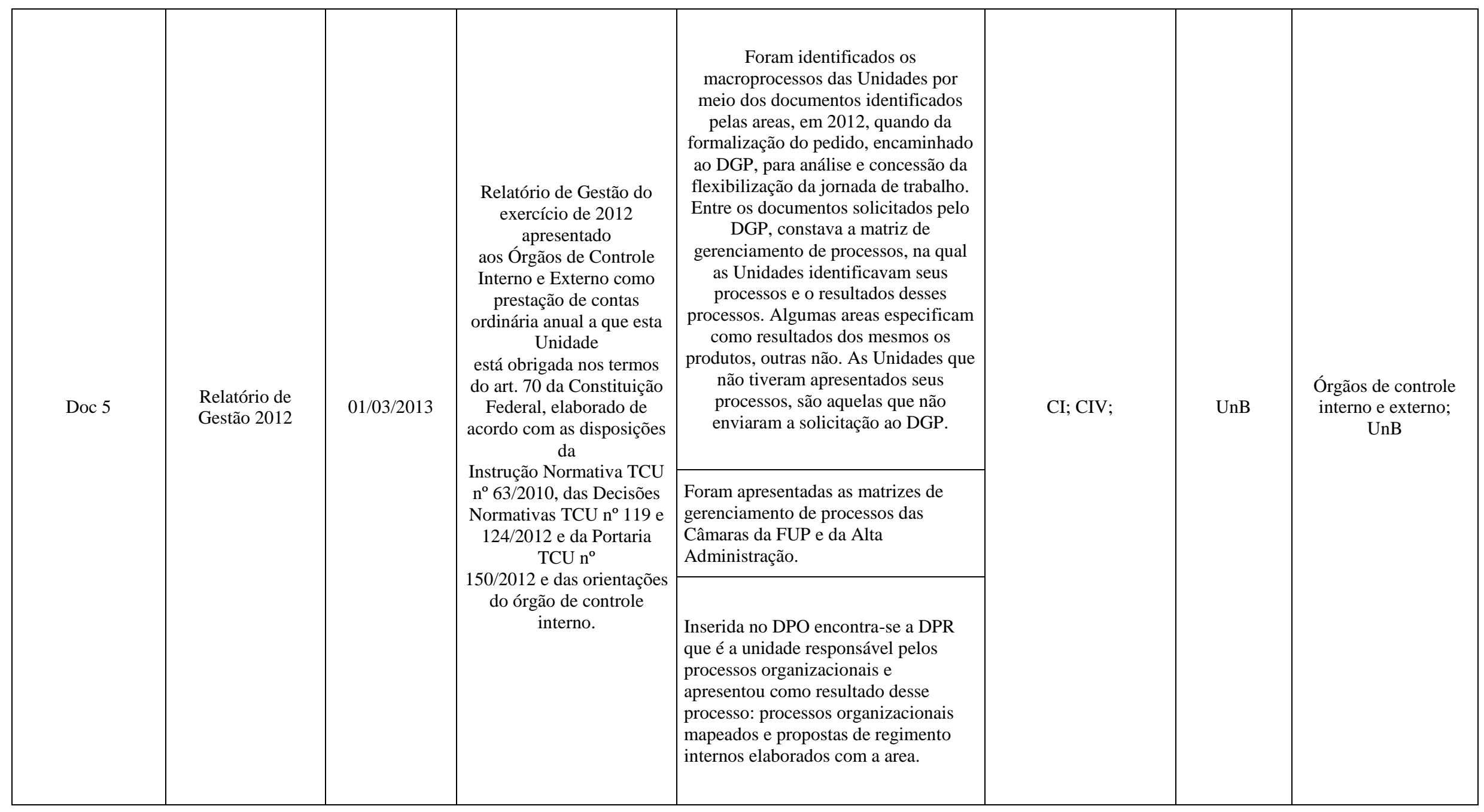




\begin{tabular}{|c|c|c|c|c|c|c|c|}
\hline Doc 5 & $\begin{array}{l}\text { Relatório de } \\
\text { Gestão } 2012\end{array}$ & $01 / 03 / 2013$ & $\begin{array}{c}\text { Relatório de Gestão do } \\
\text { exercício de } 2012 \\
\text { apresentado } \\
\text { aos Órgãos de Controle } \\
\text { Interno e Externo como } \\
\text { prestação de contas } \\
\text { ordinária anual a que esta } \\
\text { Unidade } \\
\text { está obrigada nos termos } \\
\text { do art. } 70 \text { da Constituição } \\
\text { Federal, elaborado de } \\
\text { acordo com as disposições } \\
\text { da } \\
\text { Instrução Normativa TCU } \\
\mathrm{n}^{\circ} 63 / 2010 \text {, das Decisões } \\
\text { Normativas TCU n } 119 \text { e } \\
\text { 124/2012 e da Portaria } \\
\text { TCU n }{ }^{\circ} \\
\text { 150/2012 e das orientações } \\
\text { do órgão de controle } \\
\text { interno. }\end{array}$ & $\begin{array}{l}\text { Descrição dos macroprocessos e } \\
\text { processos finalísticos da UnB, } \\
\text { referenciados pela Unidade } \\
\text { responsável e elaborados pela DPR, } \\
\text { porém não foram apresentados os } \\
\text { detalhamentos de cada processo. } \\
\text { Macroprocessos finalísticos: } \\
\text { Graduação e Programas de Apoio; } \\
\text { Pós-Graduação; Pesquisa; e Extensão } \\
\text { de Ações à Comunidade. }\end{array}$ & CI; CIV; & UnB & $\begin{array}{c}\text { Órgãos de controle } \\
\text { interno e externo; } \\
\text { UnB }\end{array}$ \\
\hline
\end{tabular}




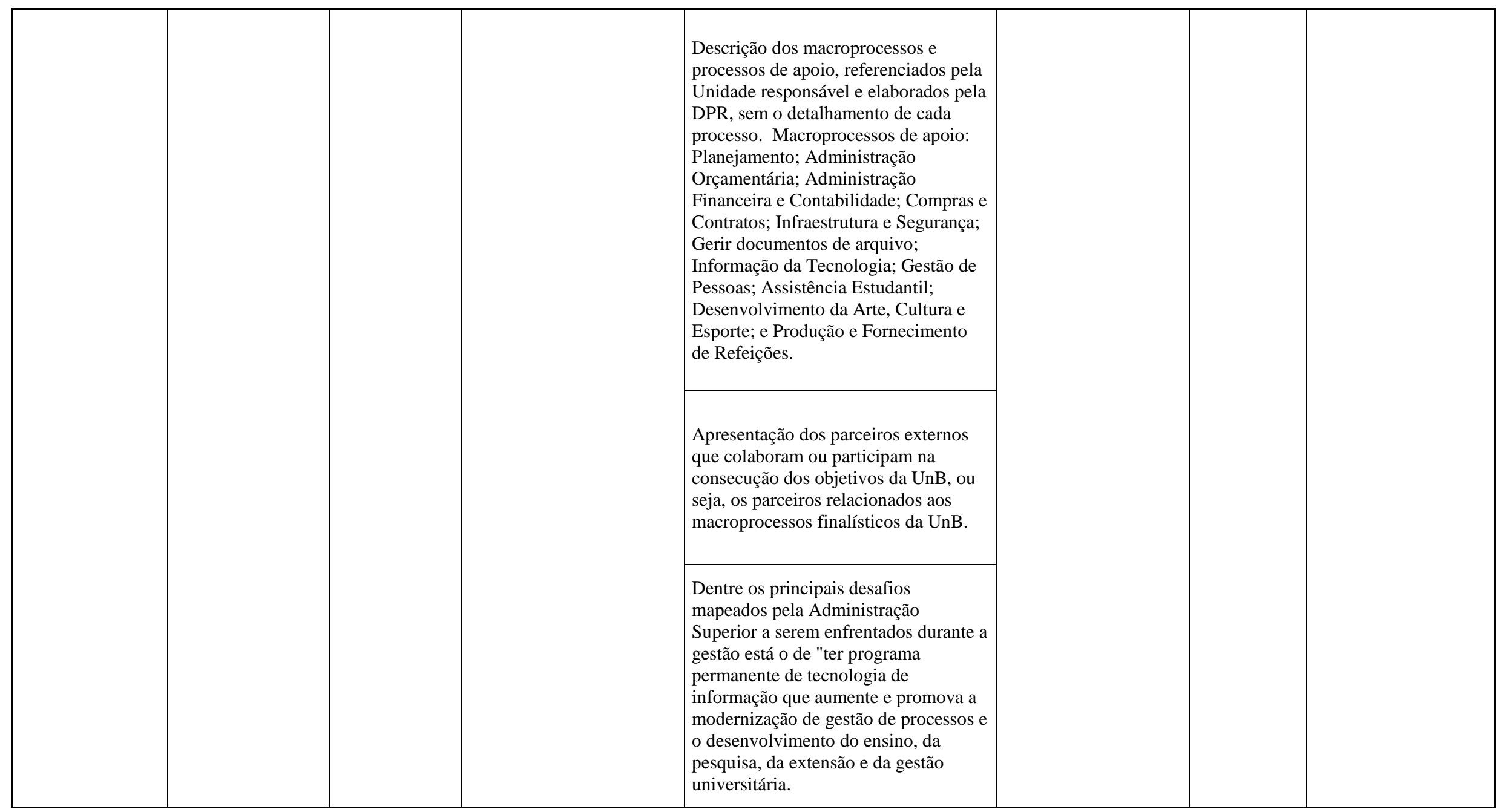




\begin{tabular}{|c|c|c|c|c|c|c|c|}
\hline Doc 5 & $\begin{array}{l}\text { Relatório de } \\
\text { Gestão } 2012\end{array}$ & $01 / 03 / 2013$ & $\begin{array}{c}\text { Relatório de Gestão do } \\
\text { exercício de } 2012 \\
\text { apresentado } \\
\text { aos Órgãos de Controle } \\
\text { Interno e Externo como } \\
\text { prestação de contas } \\
\text { ordinária anual a que esta } \\
\text { Unidade } \\
\text { está obrigada nos termos } \\
\text { do art. } 70 \text { da Constituição } \\
\text { Federal, elaborado de } \\
\text { acordo com as disposições } \\
\text { da } \\
\text { Instrução Normativa TCU } \\
\mathrm{n}^{\circ} \text { 63/2010, das Decisões } \\
\text { Normativas TCU n } 119 \text { e } \\
\text { 124/2012 e da Portaria } \\
\text { TCU n } \\
\text { 150/2012 e das orientações } \\
\text { do órgão de controle } \\
\text { interno. }\end{array}$ & $\begin{array}{l}\text { Dentre os objetivos estratégicos } \\
\text { consta: "Ter excelência e transparência } \\
\text { na comunicação institucional, em } \\
\text { ações de tecnologia da informação, na } \\
\text { gestão de meios, do patrimônio e de } \\
\text { processos. Dentre as metas } \\
\text { apresentadas para o alcance desse } \\
\text { objetivo está a de Integrar } 100 \% \text { dos } \\
\text { sistemas utilizando plataforma de } \\
\text { software livre que tem por ação } \\
\text { "promover o mapeamento e a } \\
\text { documentação dos processos de gestão } \\
\text { administrativa e acadêmica visando } \\
\text { automação e transparência". }\end{array}$ & CI; CIV; & UnB & $\begin{array}{c}\text { Órgãos de controle } \\
\text { interno e externo; } \\
\text { UnB }\end{array}$ \\
\hline
\end{tabular}




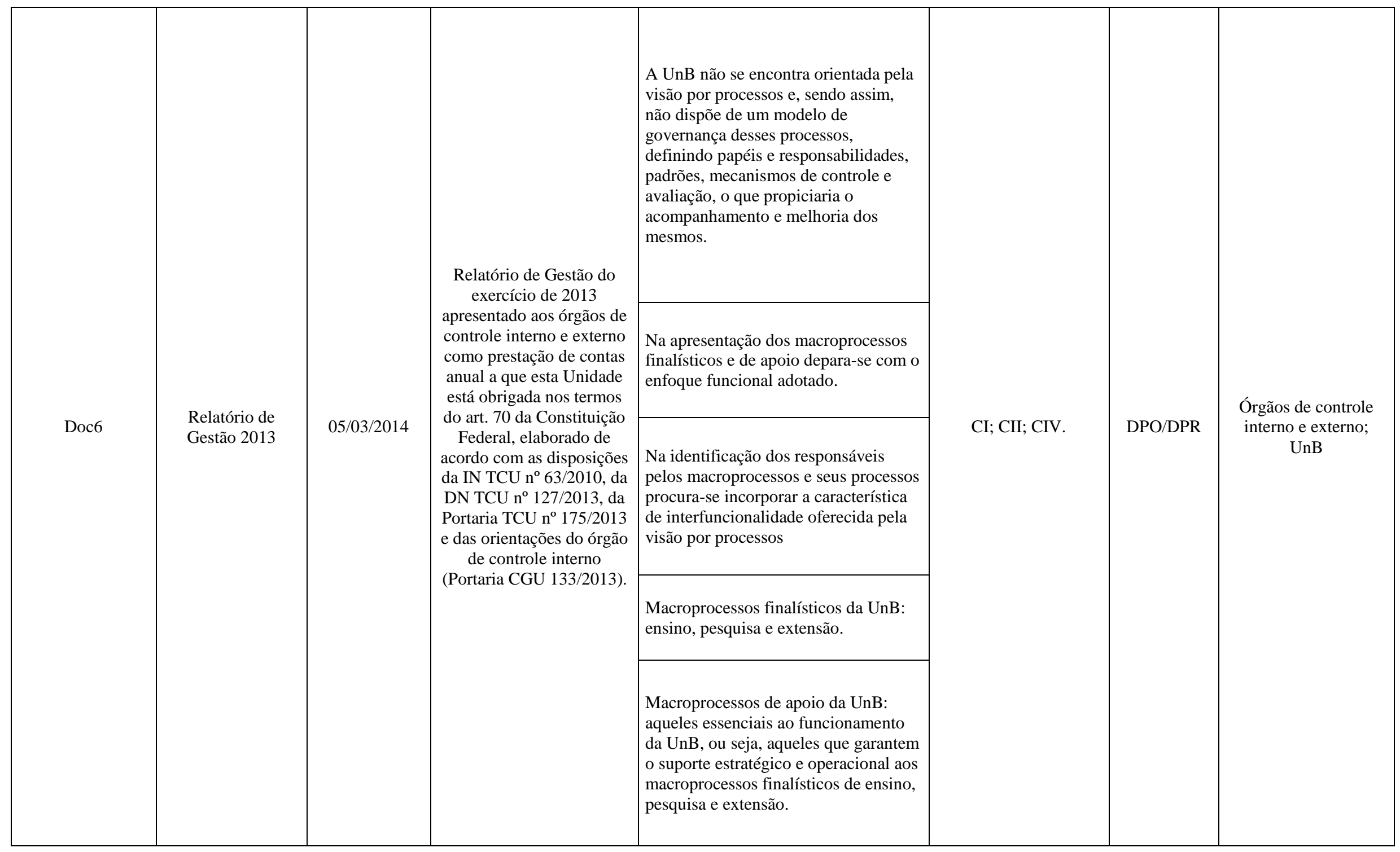




\begin{tabular}{|c|c|c|c|c|c|c|c|}
\hline \multirow{5}{*}{ Doc6 } & \multirow{5}{*}{$\begin{array}{l}\text { Relatório de } \\
\text { Gestão } 2013\end{array}$} & \multirow{5}{*}{$05 / 03 / 2014$} & \multirow{5}{*}{$\begin{array}{l}\text { Relatório de Gestão do } \\
\text { exercício de } 2013 \\
\text { apresentado aos órgãos de } \\
\text { controle interno e externo } \\
\text { como prestação de contas } \\
\text { anual a que esta Unidade } \\
\text { está obrigada nos termos } \\
\text { do art. } 70 \text { da Constituição } \\
\text { Federal, elaborado de } \\
\text { acordo com as disposições } \\
\text { da IN TCU n }{ }^{\circ} 63 / 2010, \text { da } \\
\text { DN TCU n }{ }^{\circ} 127 / 2013 \text {, da } \\
\text { Portaria TCU no 175/2013 } \\
\text { e das orientações do órgão } \\
\text { de controle interno } \\
\text { (Portaria CGU 133/2013). }\end{array}$} & $\begin{array}{l}\text { Macroprocessos de apoio são: Gestão } \\
\text { Estratégica e Orçamentária; Gestão } \\
\text { Financeira e Contábil; Gestão de } \\
\text { Compras e Contratações; Gestão de } \\
\text { Pessoas; Gestão de Infraestrutura e } \\
\text { Segurança; Gestão da Informação e } \\
\text { Tecnologia; Assistência à Comunidade } \\
\text { Universitária. }\end{array}$ & \multirow{5}{*}{ CI; CII; CIV. } & \multirow{5}{*}{ DPO/DPR } & \multirow{5}{*}{$\begin{array}{c}\text { Órgãos de controle } \\
\text { interno e externo; } \\
\text { UnB }\end{array}$} \\
\hline & & & & $\begin{array}{l}\text { Inseridos em cada macroprocesso de } \\
\text { apoio existem os processos. }\end{array}$ & & & \\
\hline & & & & $\begin{array}{l}\text { O macroprocesso Gestão Estratégica e } \\
\text { Orçamentária possui o processo de } \\
\text { Desenvolvimento Organizacional. }\end{array}$ & & & \\
\hline & & & & $\begin{array}{l}\text { Na descrição do processo } \\
\text { Desenvolvimento Organizacional } \\
\text { estão descritos o Mapeamento dos } \\
\text { Processos e o Redesenho dos } \\
\text { Processos, junto com seus respectivos } \\
\text { produtos/serviços. }\end{array}$ & & & \\
\hline & & & & $\begin{array}{l}\text { Consta a informação de que no ano de } \\
\text { 2013, foi iniciado o mapeamento (AS } \\
\text { IS) dos processos organizacionais do } \\
\text { Centro de Documentação da UnB - } \\
\text { CEDOC, do DEX e do DPO. }\end{array}$ & & & \\
\hline
\end{tabular}




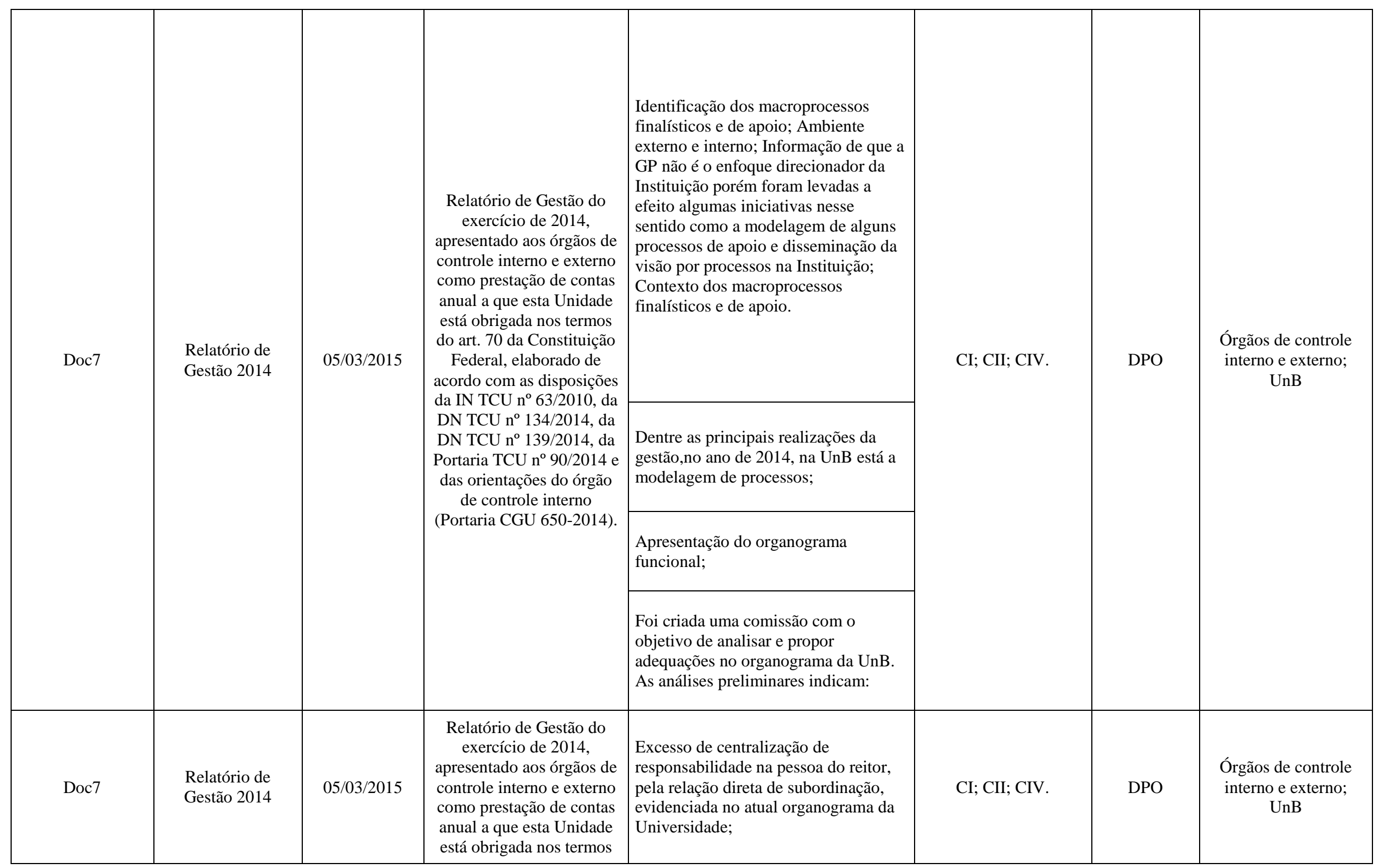




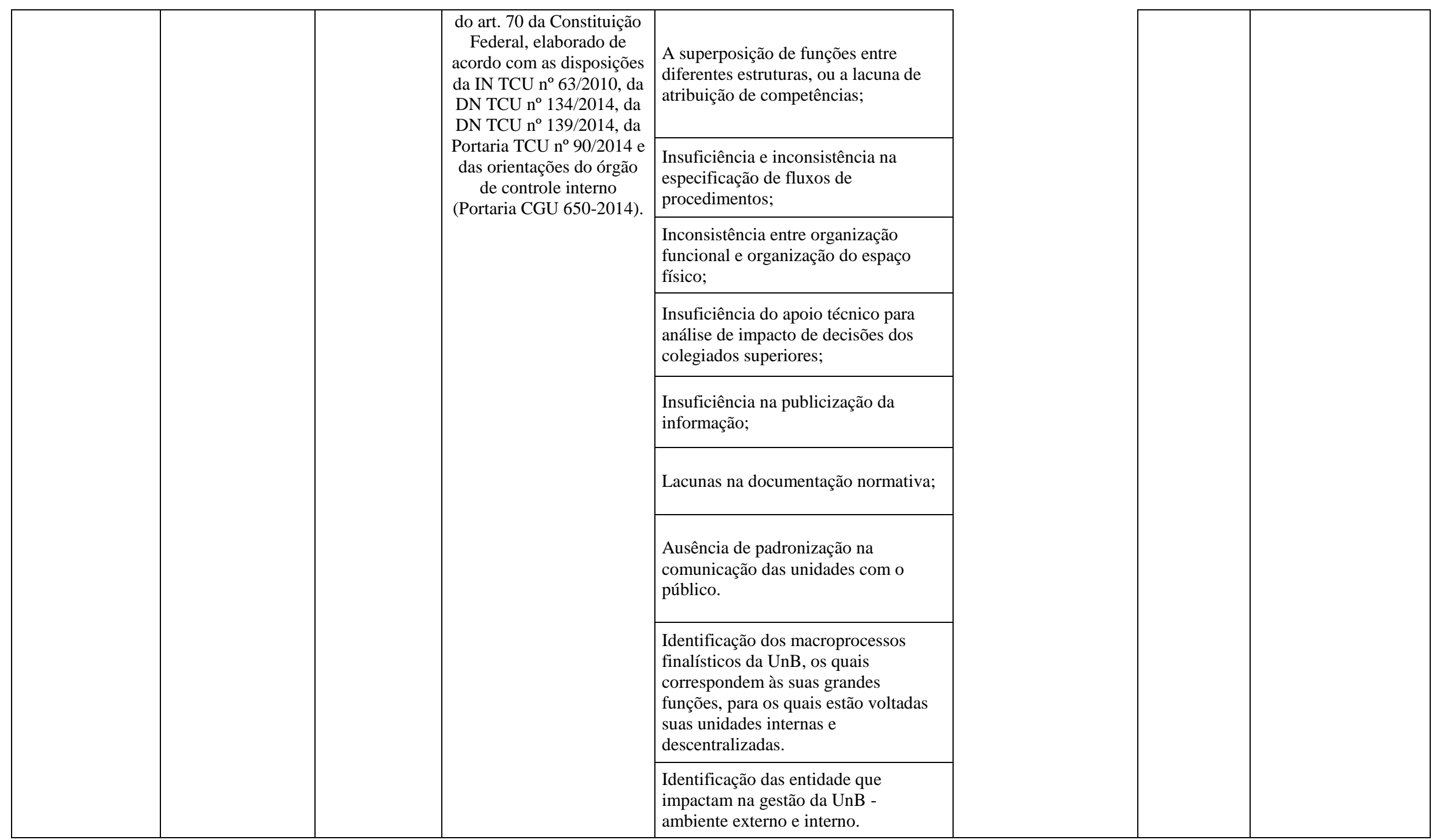




\begin{tabular}{|c|c|c|c|c|c|c|}
\hline & & & & $\begin{array}{l}\text { Apesar da gestão por processos não ser } \\
\text { o enfoque direcionador da Instituição, } \\
\text { no ano de 2014, foram levadas a efeito } \\
\text { algumas iniciativas nesse sentido, } \\
\text { embora não integradas à gestão } \\
\text { estratégica, de modelagem de alguns } \\
\text { macroprocessos de apoio e de } \\
\text { dissiminação da visão por processos } \\
\text { na UnB. }\end{array}$ & & \\
\hline \multirow{7}{*}{ Doc7 } & \multirow{7}{*}{$\begin{array}{l}\text { Relatório de } \\
\text { Gestão } 2014\end{array}$} & \multirow{7}{*}{ 05/03/2015 } & \multirow{7}{*}{$\begin{array}{l}\text { Relatório de Gestão do } \\
\text { exercício de 2014, } \\
\text { apresentado aos órgãos de } \\
\text { controle interno e externo } \\
\text { como prestação de contas } \\
\text { anual a que esta Unidade } \\
\text { está obrigada nos termos } \\
\text { do art. } 70 \text { da Constituição } \\
\text { Federal, elaborado de } \\
\text { acordo com as disposições } \\
\text { da IN TCU no } \text { n }^{\circ} \text { 63/2010, da } \\
\text { DN TCU n }{ }^{\circ} 134 / 2014, \text { da } \\
\text { DN TCU n } 139 / 2014, \text { da } \\
\text { Portaria TCU no 90/2014 e } \\
\text { das orientações do órgão } \\
\text { de controle interno } \\
\text { (Portaria CGU 650-2014). }\end{array}$} & $\begin{array}{l}\text { Definição da Missão e Visão de Futuro } \\
\text { (a mesma do Relatório de 2013) }\end{array}$ & \multirow{7}{*}{ DPO } & \multirow{7}{*}{$\begin{array}{l}\text { Órgãos de controle } \\
\text { interno e externo; } \\
\text { UnB }\end{array}$} \\
\hline & & & & $\begin{array}{l}\text { Objetivos e estratégias foram } \\
\text { estabelecidos para o alcance dos } \\
\text { resultados pretendidos. Em relação à } \\
\text { gestão interna (processos e modelos de } \\
\text { gestão), tem-se como um dos objetivos } \\
\text { a implantação da gestão por processos. }\end{array}$ & & \\
\hline & & & & $\begin{array}{l}\text { As estratégias traçadas para o } \\
\text { cumprimento da implantação da gestão } \\
\text { por processos são: }\end{array}$ & & \\
\hline & & & & $\begin{array}{l}\text { Definir o modelo de governança de } \\
\text { processos; }\end{array}$ & & \\
\hline & & & & $\begin{array}{l}\text { Elaborar programa de capacitação em } \\
\text { gestão por processos para gestores e } \\
\text { executores; }\end{array}$ & & \\
\hline & & & & $\begin{array}{l}\text { Estabelecimento de metodologia e } \\
\text { padrões para mapeamento e } \\
\text { modelagem dos processos; }\end{array}$ & & \\
\hline & & & & $\begin{array}{l}\text { Disseminar a cultura da visão por } \\
\text { processos; }\end{array}$ & & \\
\hline
\end{tabular}




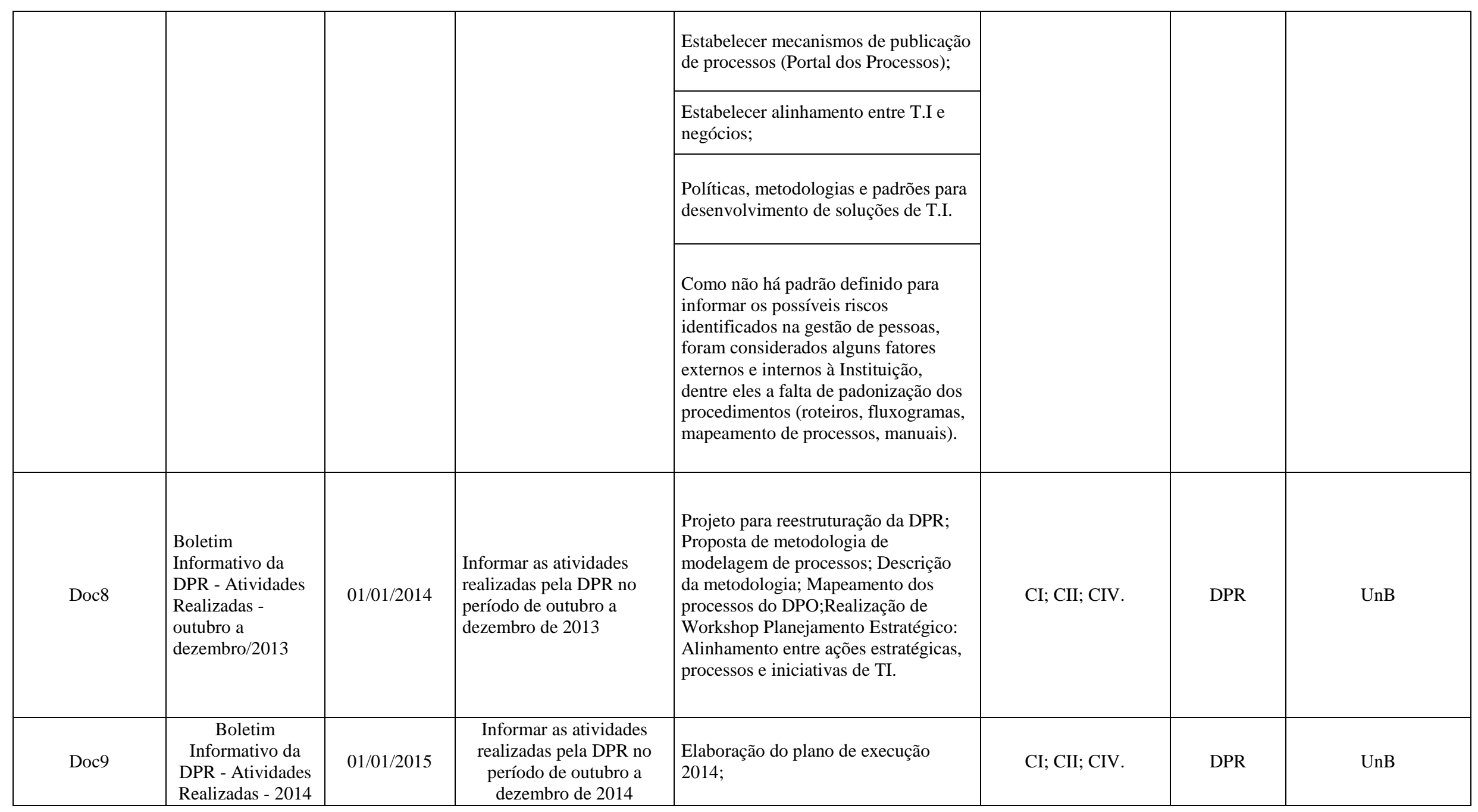




\begin{tabular}{|c|c|c|c|c|c|c|c|}
\hline & & & & $\begin{array}{l}\text { Pojeto de implantação da gestão por } \\
\text { processos na UnB: Apresentação sobre } \\
\text { gestão por processos na UnB; } \\
\text { elaboração do documento de proposta } \\
\text { para implantação e assinatura do } \\
\text { Reitor; elaboração em parceria com a } \\
\text { consultoria a ser contratada da } \\
\text { proposta de trabalho para a } \\
\text { implantação da GP; apresentação da } \\
\text { proposta da consultora para a alta } \\
\text { administração e entrega; }\end{array}$ & & & \\
\hline & & & & $\begin{array}{l}\text { Projeto Mapeamento dos processos do } \\
\text { Arquivo Central da UnB: autuar } \\
\text { documentos de arquivo, movimentar } \\
\text { documentos de arquivo, avaliar } \\
\text { documentos de arquivo, descrever } \\
\text { documentos de arquivo, conservar } \\
\text { documentos de arquivo e acessar } \\
\text { documentos de arquivo. }\end{array}$ & & & \\
\hline & & & & $\begin{array}{l}\text { Delimitação das competências entre } \\
\text { DAF/DPO: entrega do descritor e dos } \\
\text { mapas do processo "elaboração e } \\
\text { ececução do orçamento". }\end{array}$ & & & \\
\hline Doc10 & $\begin{array}{c}\text { Decreto } \\
6.932 / 2009\end{array}$ & $11 / 08 / 2009$ & $\begin{array}{l}\text { dispõe sobre a } \\
\text { simplificação no } \\
\text { atendimento publico } \\
\text { prestado ao cidadão }\end{array}$ & Transparência nos processos & $\mathrm{CI}$ & GF & Ips \\
\hline
\end{tabular}




\begin{tabular}{|c|c|c|c|c|c|c|c|}
\hline Doc11 & Lei 12.527 & $18 / 11 / 2011$ & $\begin{array}{l}\text { obriga órgão e instituições } \\
\text { públicas a fornecerem } \\
\text { informações sobre seus } \\
\text { processos de modo a } \\
\text { fortalecer a participação do } \\
\text { cidadão, permitindo o } \\
\text { acesso e conhecimento dos } \\
\text { seus direitos essenciais }\end{array}$ & Transparência nos processos & CI & GF & Ips \\
\hline
\end{tabular}

